\title{
Cochrane
}

Library

Cochrane Database of Systematic Reviews

\section{Interventions for prophylaxis of hepatic veno-occlusive disease in people undergoing haematopoietic stem cell transplantation} (Review)

Cheuk DKL, Chiang AKS, Ha SY, Chan GCF

Cheuk DKL, Chiang AKS, Ha SY, Chan GCF.

Interventions for prophylaxis of hepatic veno-occlusive disease in people undergoing haematopoietic stem cell transplantation.

Cochrane Database of Systematic Reviews 2015, Issue 5. Art. No.: CD009311.

DOI: 10.1002/14651858.CD009311.pub2.

www.cochranelibrary.com

Interventions for prophylaxis of hepatic veno-occlusive disease in people undergoing haematopoietic stem cell 
TABLE OF CONTENTS

HEADER

ABSTRACT

PLAIN LANGUAGE SUMMARY

SUMMARY OF FINDINGS

BACKGROUND

OBJECTIVES

METHODS

RESULTS

Figure 1.

Figure 2.

Figure 3.

Figure 4.

Figure 5.

DISCUSSION

AUTHORS' CONCLUSIONS

ACKNOWLEDGEMENTS

REFERENCES

CHARACTERISTICS OF STUDIES

DATA AND ANALYSES

Analysis 1.1. Comparison 1 Ursodeoxycholic acid versus placebo or no treatment, Outcome 1 Incidence of hepatic VOD. .......

Analysis 1.2. Comparison 1 Ursodeoxycholic acid versus placebo or no treatment, Outcome 2 Overall survival. ......................

Analysis 1.3. Comparison 1 Ursodeoxycholic acid versus placebo or no treatment, Outcome 3 All-cause mortality at 100 days post-transplant.

Analysis 1.4. Comparison 1 Ursodeoxycholic acid versus placebo or no treatment, Outcome 4 Mortality attributable to hepatic VOD.

Analysis 1.5. Comparison 1 Ursodeoxycholic acid versus placebo or no treatment, Outcome 5 Frequency of adverse events. .... Analysis 2.1. Comparison 2 Heparin versus no treatment, Outcome 1 Incidence of hepatic VOD.

Analysis 2.2. Comparison 2 Heparin versus no treatment, Outcome 2 Overall survival.

Analysis 2.3. Comparison 2 Heparin versus no treatment, Outcome 3 All-cause mortality at 100 days post-transplant. ............ Analysis 2.4. Comparison 2 Heparin versus no treatment, Outcome 4 Mortality attributable to hepatic VOD. ........................... Analysis 2.5. Comparison 2 Heparin versus no treatment, Outcome 5 Frequency of adverse events.

Analysis 3.1. Comparison 3 Low molecular weight heparin versus placebo or no treatment, Outcome 1 Incidence of hepatic VOD.

Analysis 3.2. Comparison 3 Low molecular weight heparin versus placebo or no treatment, Outcome 2 Frequency of adverse events.

Analysis 4.1. Comparison 4 Defibrotide versus no treatment, Outcome 1 Incidence of hepatic VOD.

Analysis 4.2. Comparison 4 Defibrotide versus no treatment, Outcome 2 Subgroup analyses of incidence of hepatic VOD by age groups.

Analysis 4.3. Comparison 4 Defibrotide versus no treatment, Outcome 3 Subgroup analysis for incidence of hepatic VOD by underlying diseases.

Analysis 4.4. Comparison 4 Defibrotide versus no treatment, Outcome 4 Subgroup analysis of incidence of hepatic VOD by type of transplant.

Analysis 4.5. Comparison 4 Defibrotide versus no treatment, Outcome 5 Overall survival.

Analysis 4.6. Comparison 4 Defibrotide versus no treatment, Outcome 6 All-cause mortality at 100 days post-transplant Analysis 4.7. Comparison 4 Defibrotide versus no treatment, Outcome 7 Mortality attributable to hepatic VOD.

Analysis 4.8. Comparison 4 Defibrotide versus no treatment, Outcome 8 Frequency of adverse events.

Analysis 4.9. Comparison 4 Defibrotide versus no treatment, Outcome 9 Frequency of severe adverse events.

Analysis 4.10. Comparison 4 Defibrotide versus no treatment, Outcome 10 Frequency of haemorrhage.

Analysis 5.1. Comparison 5 Glutamine versus placebo, Outcome 1 All-cause mortality at 100 days post-transplant.

Analysis 5.2. Comparison 5 Glutamine versus placebo, Outcome 2 Frequency of adverse events.

Analysis 6.1. Comparison 6 Fresh frozen plasma versus no treatment, Outcome 1 Incidence of hepatic VOD.

Analysis 7.1. Comparison 7 Antithrombin III plus heparin versus heparin alone, Outcome 1 Incidence of hepatic VOD. 
Analysis 7.2. Comparison 7 Antithrombin III plus heparin versus heparin alone, Outcome 2 Frequency of adverse events. ...... 71 Analysis 8.1. Comparison 8 Heparin versus low molecular weight heparin, Outcome 1 Incidence of hepatic VOD. ................... 72 Analysis 8.2. Comparison 8 Heparin versus low molecular weight heparin, Outcome 2 Mortality attributable to hepatic VOD. ... 72 Analysis 8.3. Comparison 8 Heparin versus low molecular weight heparin, Outcome 3 Frequency of adverse events. .............. 72

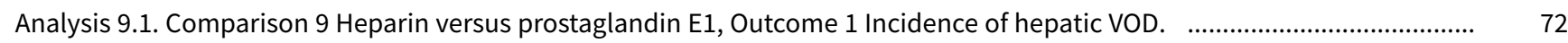
Analysis 9.2. Comparison 9 Heparin versus prostaglandin E1, Outcome 2 Mortality attributable to hepatic VOD. ...................... 73 Analysis 9.3. Comparison 9 Heparin versus prostaglandin E1, Outcome 3 Frequency of adverse events. .................................... 73 Analysis 10.1. Comparison 10 Low molecular weight heparin versus prostaglandin E1, Outcome 1 Incidence of hepatic VOD. ... 73 Analysis 10.2. Comparison 10 Low molecular weight heparin versus prostaglandin E1, Outcome 2 Mortality attributable to 73 hepatic VOD.

Analysis 10.3. Comparison 10 Low molecular weight heparin versus prostaglandin E1, Outcome 3 Frequency of adverse events.

APPENDICES

CONTRIBUTIONS OF AUTHORS

DECLARATIONS OF INTEREST

SOURCES OF SUPPORT

DIFFERENCES BETWEEN PROTOCOL AND REVIEW 
[Intervention Review]

\title{
Interventions for prophylaxis of hepatic veno-occlusive disease in people undergoing haematopoietic stem cell transplantation
}

\author{
Daniel KL Cheuk ${ }^{1}$, Alan KS Chiang ${ }^{1}$, Shau Yin $\mathrm{Ha}^{1}$, Godfrey CF Chan ${ }^{1}$
}

1Department of Pediatrics and Adolescent Medicine, The University of Hong Kong, Queen Mary Hospital, Hong Kong SAR, China

Contact address: Daniel KL Cheuk, Department of Pediatrics and Adolescent Medicine, The University of Hong Kong, Queen Mary Hospital, Pokfulam Road, Hong Kong SAR, China. cheukkld@hkucc.hku.hk.

Editorial group: Cochrane Haematological Malignancies Group

Publication status and date: New, published in Issue 5, 2015.

Citation: Cheuk DKL, Chiang AKS, Ha SY, Chan GCF. Interventions for prophylaxis of hepatic veno-occlusive disease in people undergoing haematopoietic stem cell transplantation. Cochrane Database of Systematic Reviews 2015, Issue 5. Art. No.: CD009311. DOI: 10.1002/14651858.CD009311.pub2.

Copyright @ 2015 The Cochrane Collaboration. Published by John Wiley \& Sons, Ltd.

\section{A B S T R A C T}

\section{Background}

Hepatic veno-occlusive disease (VOD) is a severe complication after haematopoietic stem cell transplantation (HSCT). Different drugs with different mechanisms of action have been tried in HSCT recipients to prevent hepatic VOD. However, it is uncertain whether high-quality evidence exists to support any prophylactic therapy.

\section{Objectives}

We aimed to determine the effects of various prophylactic therapies on the incidence of hepatic VOD, overall survival, mortality, quality of life (QOL), and the safety of these therapies in people undergoing HSCT.

\section{Search methods}

We searched the Cochrane Central Registe of Controlled Trials (CENTRAL), MEDLINE, EMBASE, conference proceedings of three international haematology-oncology societies and two trial registries in January 2015, together with reference checking, citation searching and contact with study authors to identify additional studies.

\section{Selection criteria}

We included randomised controlled trials (RCTs) comparing prophylactic therapies with placebo or no treatment, or comparing different therapies for hepatic VOD in people undergoing HSCT.

\section{Data collection and analysis}

We used standard methodological procedures expected by Cochrane.

\section{Main results}

We included 14 RCTs. Four trials (612 participants) compared ursodeoxycholic acid with or without additional treatment versus placebo or no treatment or same additional treatment. Two trials (259 participants) compared heparin with no treatment. Two trials (106 participants) compared low molecular weight heparin (LMWH) with placebo or no treatment. One trial (360 participants) compared defibrotide with no treatment. One trial (34 participants) compared glutamine with placebo. Two trials (383 participants) compared fresh frozen plasma (FFP) with or without additional treatment versus no treatment or same additional treatment. One trial (30 participants) compared antithrombin III with heparin versus heparin. One trial compared heparin (47 participants) with LMWH (46 participants) and prostaglandin E1 (PGE1) (47 participants). No trial investigated the effects of danaparoid. The RCTs included participants of both genders with wide age range and disease spectrum undergoing autologous or allogeneic HSCT. Funding was provided by government sources (two studies), research 
fund (one study), pharmaceutical companies that manufactured defibrotide and ursodeoxycholic acid (two studies), or unclear source (nine studies). All RCTs had high risk of bias because of lack of blinding of participants and study personnel, or other risks of bias (mainly differences in baseline characteristics of comparison groups).

Results showed that ursodeoxycholic acid may reduce the incidence of hepatic VOD (risk ratio (RR) $0.60,95 \%$ confidence interval (CI) 0.40 to 0.88 ; number needed to treat for an additional beneficial outcome (NNTB) $15,95 \% \mathrm{Cl} 7$ to 50 , low quality of evidence), but there was no evidence of difference in overall survival (hazard ratio (HR) $0.83,95 \% \mathrm{Cl} 0.59$ to 1.18 , low quality of evidence). It may reduce all-cause mortality (RR $0.70,95 \% \mathrm{Cl} 0.50$ to 0.99 ; NNTB $17,95 \% \mathrm{Cl} 8$ to 431 , low quality of evidence) and mortality due to hepatic VOD (RR $0.27,95 \%$ $\mathrm{Cl} 0.09$ to 0.87 ; NNTB $34,95 \% \mathrm{Cl} 16$ to 220 , very low quality of evidence). There was no evidence of difference in the incidence of hepatic VOD between treatment and control groups for heparin (RR $0.47,95 \% \mathrm{Cl} 0.18$ to 1.26 , very low quality of evidence), $\mathrm{LMWH}$ (RR $0.27,95 \% \mathrm{Cl}$ 0.06 to 1.18 , very low quality of evidence), defibrotide (RR $0.62,95 \% \mathrm{Cl} 0.38$ to 1.02 , low quality of evidence), glutamine (no hepatic VOD in either group, very low quality of evidence), $\mathrm{FFP}$ (RR $0.66,95 \% \mathrm{Cl} 0.20$ to 2.17 , very low quality of evidence), antithrombin III (RR $0.13,95 \% \mathrm{Cl}$ 0.01 to 2.15 , very low quality of evidence), between heparin and LMWH (RR $1.96,95 \% \mathrm{Cl} 0.80$ to 4.77 , very low quality of evidence), between heparin and PGE1 (RR 1.20, 95\% Cl 0.58 to 2.50 , very low quality of evidence), and between LMWH and PGE1 (RR $0.61,95 \% \mathrm{Cl} 0.24$ to 1.55 , very low quality of evidence). There was no evidence of difference in survival between treatment and control groups for heparin (92.6\% vs. $88.7 \%$ ) and defibrotide (HR 1.04, 95\% CI 0.54 to 2.02, low quality of evidence). There were no data on survival for trials of LMWH, glutamine, FFP, antithrombin III, between heparin and LMWH, between heparin and PGE1, and between LMWH and PGE1. There were no data on quality of life (QoL) for any trials. Eleven trials reported adverse events. There was no evidence of difference in the frequency of adverse events between treatment and control groups except for one trial showing that defibrotide resulted in more adverse events compared with no treatment (RR $18.79,95 \% \mathrm{Cl} 1.10$ to 320.45 ). These adverse events included coagulopathy, gastrointestinal disorders, haemorrhage and microangiopathy. The quality of evidence was low or very low due to bias of study design, and inconsistent and imprecise results.

\section{Authors' conclusions}

There is low or very low quality evidence that ursodeoxycholic acid may reduce the incidence of hepatic VOD, all-cause mortality and mortality due to VOD in HSCT recipients. However, the optimal regimen is not well-defined. There is insufficient evidence to support the use of heparin, LMWH, defibrotide, glutamine, FFP, antithrombin III, and PGE1. Further high-quality RCTs are needed.

\section{PLAIN LANGUAGE SUMMARY}

\section{Prevention of occlusion of small veins in the liver after blood-forming stem cell transplantation}

\section{Review Question}

We reviewed evidence about the effects of medications to prevent blockage of small veins in the liver (veno-occlusive disease or VOD) in people who undergo blood-forming stem cell transplantation (HSCT).

\section{Background}

People undergoing HSCT can develop VOD, a severe complication which may lead to their death. Various medications with different mechanisms of action have been tried to prevent VOD. These prophylactic measures include heparin, low molecular weight heparin (LMWH), danaparoid, ursodeoxycholic acid, prostaglandin E1 (PGE1), glutamine, antithrombin III, defibrotide and fresh frozen plasma (FFP). Many transplant centres routinely administer these preventive measures, especially for people at high risk.

\section{Study Characteristics}

We included 14 randomised controlled trials (RCTs). Four trials (612 participants) compared ursodeoxycholic acid with or without additional treatment versus placebo or no treatment or the same additional treatment. Two trials (259 participants) compared heparin with no treatment. Two trials (106 participants) compared low molecular weight heparin with placebo or no treatment. One trial (360 participants) compared defibrotide with no treatment. One trial (34 participants) compared glutamine with placebo. Two trials (383 participants) compared fresh frozen plasma with or without additional treatment versus no treatment or the same additional treatment. One trial (30 participants) compared antithrombin III with heparin versus heparin alone. One trial compared heparin (47 participants) with LMWH (46 participants) and prostaglandin E1 (47 participants). No trial investigated the effects of danaparoid. The RCTs included participants of both genders with a wide age range and disease spectrum undergoing HSCT. The evidence is current as of January 2015.

\section{Key Results}

Ursodeoxycholic acid may reduce the occurrence of VOD, deaths from all causes and deaths due to VOD, but there was no evidence of a difference in overall survival. There was no evidence of difference in occurrence of VOD between treatment and control groups for heparin, LMWH, defibrotide, glutamine, FFP, antithrombin III, between heparin and LMWH, between heparin and PGE1, and between LMWH and PGE1. There was no evidence of difference in survival between treatment and control groups for heparin and defibrotide. There were no data on survival for trials of LMWH, glutamine, FFP, antithrombin III, between heparin and LMWH, between heparin and PGE1, and between LMWH and PGE1. There were no data on quality of life for any trials. Eleven trials reported adverse effects. There was no evidence 
of a difference in adverse events among treatment groups, except for one trial showing that defibrotide resulted in more adverse events compared with no treatment.

\section{Quality of the Evidence}

The quality of evidence for all outcomes was low to very low, because of high risk of bias in study design, results inconsistent across studies and imprecision of results.

\section{Conclusion}

There is low or very low quality evidence that ursodeoxycholic acid may reduce the incidence of hepatic VOD, overall mortality and mortality due to VOD in people undergoing HSCT. However, the most effective treatment is not well-defined. There is insufficient evidence to support the use of heparin, low molecular weight heparin, defibrotide, glutamine, FFP, antithrombin III, and prostaglandin E1. Further high-quality research is needed. 
SUMMARY OF FINDINGS

Summary of findings for the main comparison. Summary of findings: Ursodeoxycholic acid versus placebo or no treatment

Ursodeoxycholic acid compared with placebo or no treatment for prophylaxis of hepatic veno-occlusive disease

Patient or population: People undergoing stem cell transplant with a variety of malignant and non-malignant diseases

Settings: Inpatients

Intervention: Ursodeoxycholic acid

Comparison: Placebo or no treatment

\begin{tabular}{|c|c|c|c|c|c|c|}
\hline \multirow[t]{3}{*}{ Outcomes } & \multicolumn{2}{|c|}{ Illustrative comparative risks* $(95 \% \mathrm{Cl})$} & \multirow{3}{*}{$\begin{array}{l}\text { Relative effect } \\
(95 \% \mathrm{CI})\end{array}$} & \multirow{3}{*}{$\begin{array}{l}\text { No of Partici- } \\
\text { pants } \\
\text { (studies) }\end{array}$} & \multirow{3}{*}{$\begin{array}{l}\text { Quality of the } \\
\text { evidence } \\
\text { (GRADE) }\end{array}$} & \multirow[t]{3}{*}{ Comments } \\
\hline & Assumed risk & Corresponding risk & & & & \\
\hline & $\begin{array}{l}\text { Placebo or no } \\
\text { treatment }\end{array}$ & Ursodeoxycholic acid & & & & \\
\hline $\begin{array}{l}\text { Incidence of hepatic veno-occlu- } \\
\text { sive disease } \\
\text { (follow-up: } 24 \text { weeks to } 1 \text { year) }\end{array}$ & 189 per $1000^{3}$ & $\begin{array}{l}113 \text { per } 1000 \\
\text { (75 to } 167 \text { ) }\end{array}$ & $\mathbf{R R} \mathbf{0 . 6 0}$ (0.40 to 0.88 ) & $\begin{array}{l}612 \\
(4)\end{array}$ & $\begin{array}{l}\oplus \oplus \ominus \ominus \\
\text { low' }\end{array}$ & \\
\hline $\begin{array}{l}\text { Overall survival } \\
\text { (follow-up: } 1 \text { year) }\end{array}$ & 594 per $1000^{3}$ & $\begin{array}{l}663 \text { per } 1000 \\
(520 \text { to } 760)\end{array}$ & HR 0.83 (0.59 to 1.18 ) & $\begin{array}{l}474 \\
(3)\end{array}$ & $\begin{array}{l}\oplus \oplus \ominus \ominus \\
\text { low } \mathbf{1}\end{array}$ & \\
\hline $\begin{array}{l}\text { All-cause mortality at } 100 \text { days } \\
\text { post-transplant } \\
\text { (follow-up: } 100 \text { days) }\end{array}$ & 223 per $1000^{3}$ & $\begin{array}{l}\mathbf{1 5 6} \text { per } \mathbf{1 0 0 0} \\
\text { (111 to } 221 \text { ) }\end{array}$ & RR 0.70 (0.50 to 0.99 ) & $\begin{array}{l}612 \\
(4)\end{array}$ & $\begin{array}{l}\oplus \oplus \ominus \ominus \\
\text { low } \mathbf{1}\end{array}$ & \\
\hline $\begin{array}{l}\text { Mortality attributable to hepatic } \\
\text { veno-occlusive disease } \\
\text { (follow-up: } 24 \text { weeks to } 1 \text { year) }\end{array}$ & 38 per $1000^{3}$ & $\begin{array}{l}10 \text { per } 1000 \\
\text { (3 to } 33 \text { ) }\end{array}$ & RR 0.27 (0.09 to 0.87 ) & $\begin{array}{l}612 \\
(4)\end{array}$ & $\begin{array}{l}\oplus \ominus \ominus \ominus \\
\text { very low } 2\end{array}$ & \\
\hline Quality of life & Not reported & Not applicable & Not applicable & Not reported & $\begin{array}{l}\text { Not applica- } \\
\text { ble }\end{array}$ & \\
\hline Frequency of adverse events & 27 per $1000^{4}$ & $\begin{array}{l}24 \text { per } 1000 \\
(9 \text { to } 60)\end{array}$ & $\mathbf{R R} 0.90$ (0.37 to 2.22 ) & $\begin{array}{l}612 \\
(4)\end{array}$ & $\begin{array}{l}\oplus \ominus \ominus \ominus \\
\text { very low2 }\end{array}$ & \\
\hline
\end{tabular}




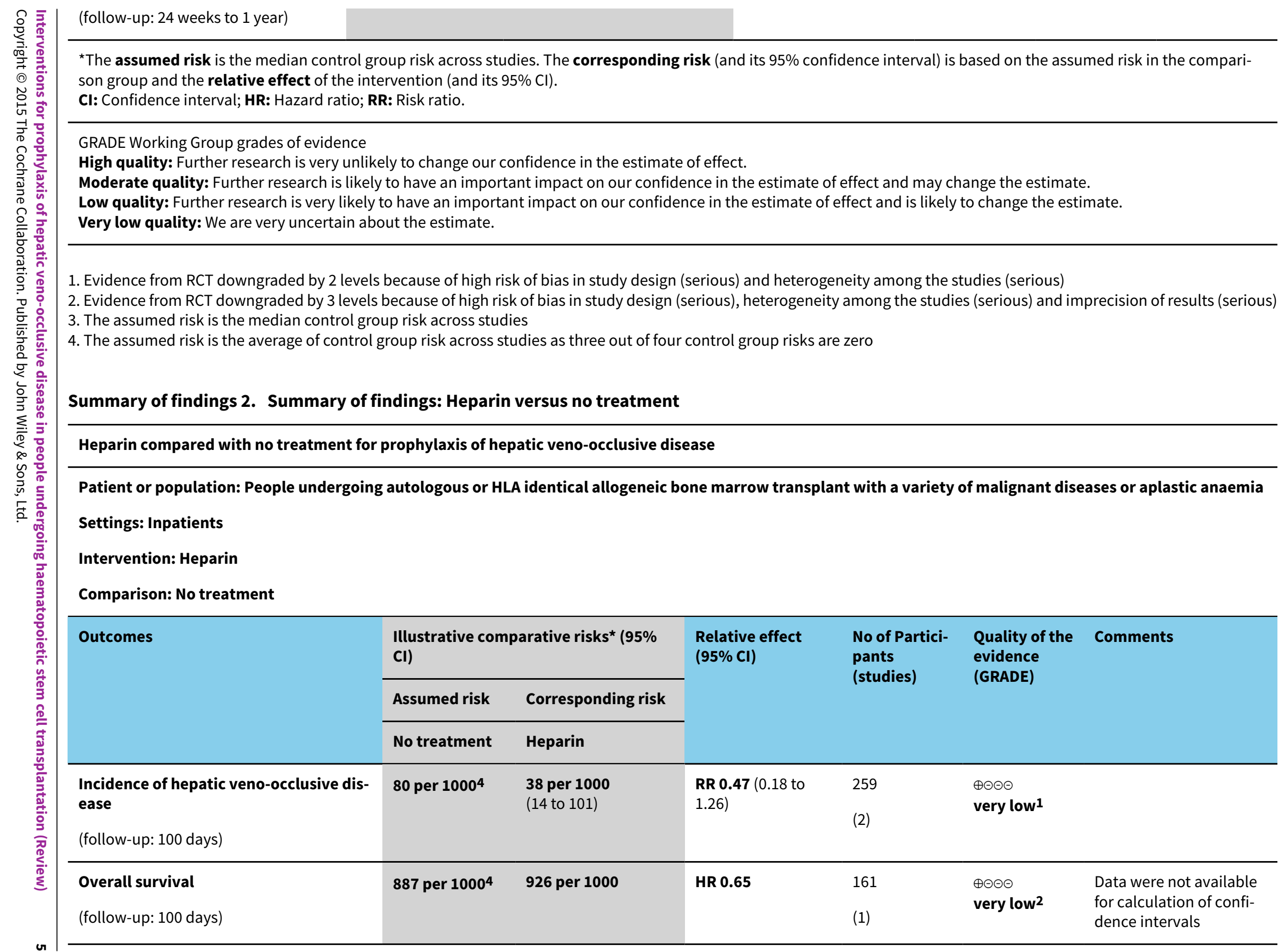

1. Evidence from RCT downgraded by 2 levels because of high risk of bias in study design (serious) and heterogeneity among the studies (serious)

2. Evidence from RCT downgraded by 3 levels because of high risk of bias in study design (serious), heterogeneity among the studies (serious) and imprecision of results (serious)

3. The assumed risk is the median control group risk across studies

\section{Summary of findings 2. Summary of findings: Heparin versus no treatment}

arin compared with no treatment for prophylaxis of hepatic veno-occlusive disease

Patient or population: People undergoing autologous or HLA identical allogeneic bone marrow transplant with a variety of malignant diseases or aplastic anaemia Settings: Inpatients

Intervention: Heparin

Comparison: No treatment 


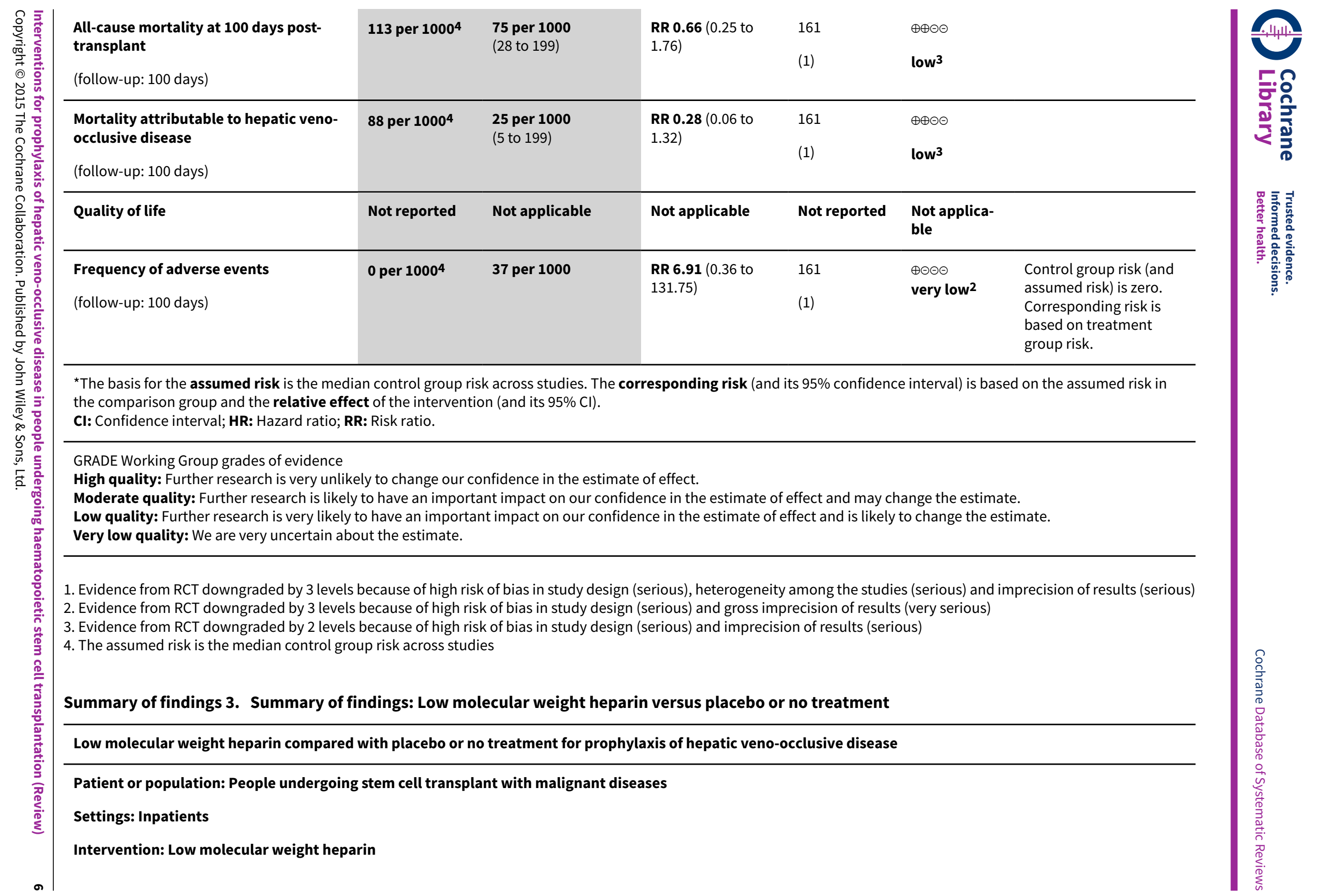




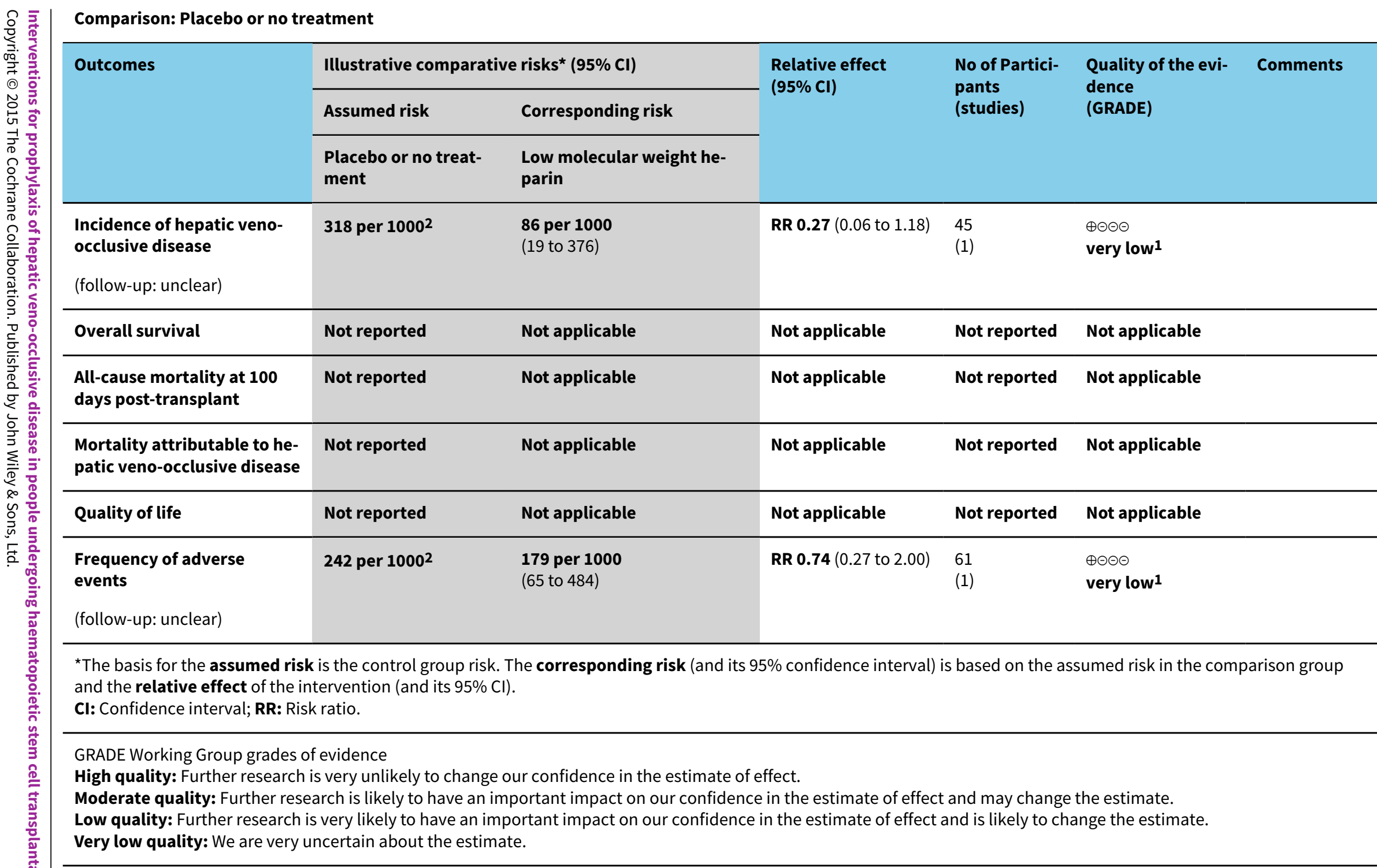

1. Evidence from RCT downgraded by 3 levels because of high risk of bias in study design (serious) and gross imprecision of results (very serious).

2. The assumed risk is the control group risk 


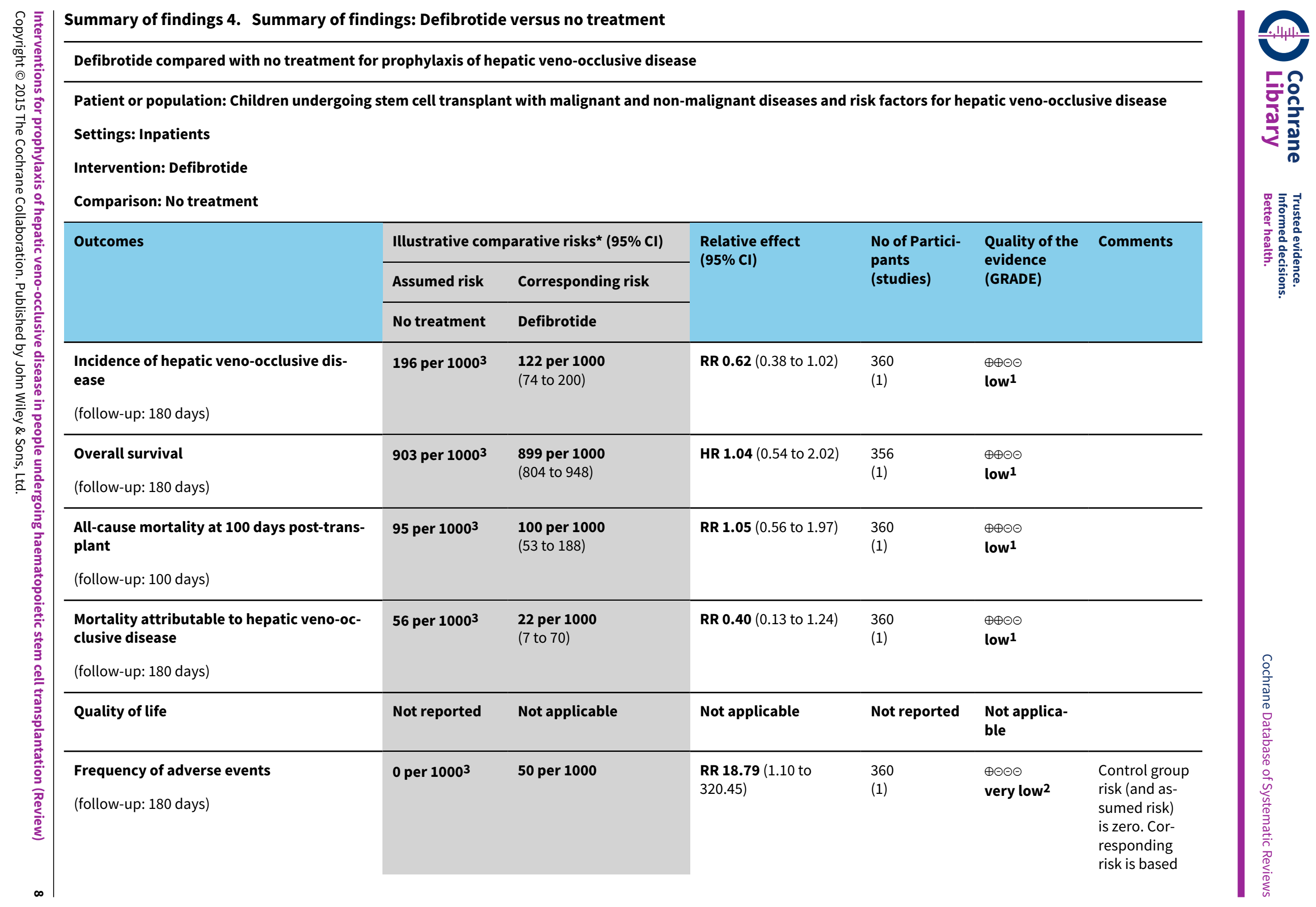



${ }^{*}$ The basis for the assumed risk is the control group risk. The corresponding risk (and its $95 \%$ confidence interval) is based on the assumed risk in the comparison group
and the relative effect of the intervention (and its $95 \% \mathrm{CI}$ ).

Cl: Confidence interval; HR: Hazard ratio; RR: Risk ratio.

GRADE Working Group grades of evidence

High quality: Further research is very unlikely to change our confidence in the estimate of effect.

Moderate quality: Further research is likely to have an important impact on our confidence in the estimate of effect and may change the estimate.

Low quality: Further research is very likely to have an important impact on our confidence in the estimate of effect and is likely to change the estimate.

Very low quality: We are very uncertain about the estimate.

1. Evidence from RCT downgraded by 2 levels because of high risk of bias in study design (serious) and imprecision of results (serious)

2. Evidence from RCT downgraded by 3 levels because of high risk of bias in study design (serious) and gross imprecision of results (very serious)

3. The assumed risk is the control group risk

\section{Summary of findings 5. Summary of findings: Glutamine versus placebo}

Glutamine compared with placebo for prophylaxis of hepatic veno-occlusive disease

Patient or population: People undergoing stem cell transplant with haematological malignancies

Settings: Inpatients

Intervention: Glutamine

Comparison: Placebo

\begin{tabular}{|c|c|c|c|c|c|c|}
\hline \multirow[t]{3}{*}{ Outcomes } & \multicolumn{2}{|c|}{$\begin{array}{l}\text { Illustrative comparative risks } \\
(95 \% \mathrm{Cl})\end{array}$} & \multirow[t]{3}{*}{$\begin{array}{l}\text { Relative effect } \\
(95 \% \mathrm{Cl})\end{array}$} & \multirow{3}{*}{$\begin{array}{l}\text { No of Partici- } \\
\text { pants } \\
\text { (studies) }\end{array}$} & \multirow{3}{*}{$\begin{array}{l}\text { Quality of the } \\
\text { evidence } \\
\text { (GRADE) }\end{array}$} & \multirow[t]{3}{*}{ Comments } \\
\hline & Assumed risk & $\begin{array}{l}\text { Corresponding } \\
\text { risk }\end{array}$ & & & & \\
\hline & Placebo & Glutamine & & & & \\
\hline $\begin{array}{l}\text { Incidence of hepatic veno-occlu- } \\
\text { sive disease } \\
\text { (follow-up: till discharge from BMT }\end{array}$ & 0 per $1000^{2}$ & 0 per 1000 & $\begin{array}{l}\text { RR not es- } \\
\text { timable }\end{array}$ & $\begin{array}{l}34 \\
(1)\end{array}$ & $\begin{array}{l}\oplus \odot \ominus \ominus \\
\text { very low } \mathbf{1}\end{array}$ & $\begin{array}{l}\text { No participant developed hepatic veno- } \\
\text { occlusive disease in either the treatment } \\
\text { or control groups }\end{array}$ \\
\hline
\end{tabular}

up: till discharge from BMT unit) 


\begin{tabular}{|c|c|c|c|c|c|c|c|c|}
\hline 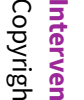 & Overall survival & Not reported & Not applicable & Not applicable & Not reported & \multicolumn{2}{|c|}{$\begin{array}{l}\text { Not applica- } \\
\text { ble }\end{array}$} & \multirow{2}{*}{ 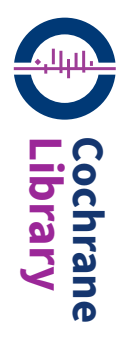 } \\
\hline 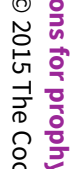 & $\begin{array}{l}\text { All-cause mortality at } 100 \text { days } \\
\text { post-transplant } \\
\text { (follow-up: } 100 \text { days) }\end{array}$ & 63 per $1000^{2}$ & $\begin{array}{l}19 \text { per } 1000 \\
(0 \text { to } 431)\end{array}$ & $\begin{array}{l}\text { RR } 0.30 \text { (0.01 to } \\
6.84 \text { ) }\end{array}$ & $\begin{array}{l}34 \\
(1)\end{array}$ & \multicolumn{2}{|l|}{$\begin{array}{l}\oplus \odot \ominus \ominus \\
\text { very low } \mathbf{1}\end{array}$} & \\
\hline 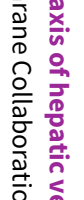 & $\begin{array}{l}\text { Mortality attributable to hepatic } \\
\text { veno-occlusive disease } \\
\text { (follow-up: till discharge from BMT } \\
\text { unit) }\end{array}$ & 0 per $1000^{2}$ & 0 per 1000 & $\begin{array}{l}\text { RR not es- } \\
\text { timable }\end{array}$ & $\begin{array}{l}34 \\
(1)\end{array}$ & $\begin{array}{l}\oplus \ominus \odot \odot \\
\text { very low } \mathbf{1}\end{array}$ & $\begin{array}{l}\text { No participant developed hepatic veno- } \\
\text { occlusive disease in either the treatment } \\
\text { or control groups }\end{array}$ & 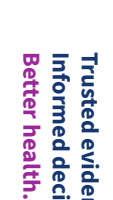 \\
\hline 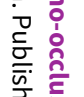 & Quality of life & Not reported & Not applicable & Not applicable & Not reported & \multicolumn{2}{|c|}{$\begin{array}{l}\text { Not applica- } \\
\text { ble }\end{array}$} & \\
\hline 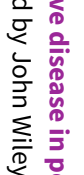 & $\begin{array}{l}\text { Frequency of adverse events } \\
\text { (follow-up: till discharge from BMT } \\
\text { unit) }\end{array}$ & 0 per $1000^{2}$ & 56 per 1000 & $\begin{array}{l}\text { RR 2.68 (0.12 to } \\
61.58)\end{array}$ & $\begin{array}{l}34 \\
(1)\end{array}$ & $\begin{array}{l}\oplus \odot \ominus \ominus \\
\text { very low } \mathbf{1}\end{array}$ & $\begin{array}{l}\text { Control group risk (and assumed risk) } \\
\text { is zero. Corresponding risk is based on } \\
\text { treatment group risk. }\end{array}$ & \\
\hline 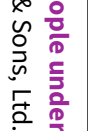 & \multicolumn{7}{|c|}{$\begin{array}{l}\text { *The basis for the assumed risk is the control group risk. The corresponding risk (and its } 95 \% \text { confidence interval) is based on the assumed risk in the comparison group } \\
\text { and the relative effect of the intervention (and its } 95 \% \mathrm{Cl} \text { ). } \\
\text { Cl: Confidence interval; RR: Risk Ratio. }\end{array}$} & \\
\hline 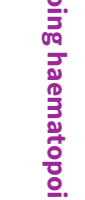 & \multicolumn{7}{|c|}{$\begin{array}{l}\text { GRADE Working Group grades of evidence } \\
\text { High quality: Further research is very unlikely to change our confidence in the estimate of effect. } \\
\text { Moderate quality: Further research is likely to have an important impact on our confidence in the estimate of effect and may change the estimate. } \\
\text { Low quality: Further research is very likely to have an important impact on our confidence in the estimate of effect and is likely to change the estimate. } \\
\text { Very low quality: We are very uncertain about the estimate. }\end{array}$} & \\
\hline 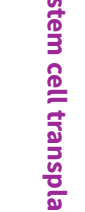 & $\begin{array}{l}\text { 1. Evidence from RCT downgraded by } \\
\text { 2. The assumed risk is the control gro } \\
\text { Summary of findings } 6 \text {. Summa }\end{array}$ & $\begin{array}{l}\text { vels because of } \\
\text { isk }\end{array}$ & igh risk of bias in & udy design (serio & ) and gross imp & cision of res & very serious) & 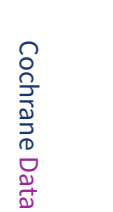 \\
\hline$\frac{2}{\tilde{t}}$ & \multicolumn{7}{|c|}{ Fresh frozen plasma compared with no treatment for prophylaxis of hepatic veno-occlusive disease } & $\begin{array}{ll}\tilde{D} \\
0 \\
0\end{array}$ \\
\hline 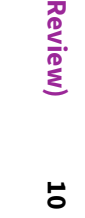 & $\begin{array}{l}\text { Patient or population: People und } \\
\text { Settings: Inpatients } \\
\text { Intervention: Fresh frozen plasma }\end{array}$ & oing stem cell & ansplants with $\mathrm{m}$ & lignant and non- & ialignant diseas & & & 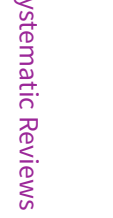 \\
\hline
\end{tabular}




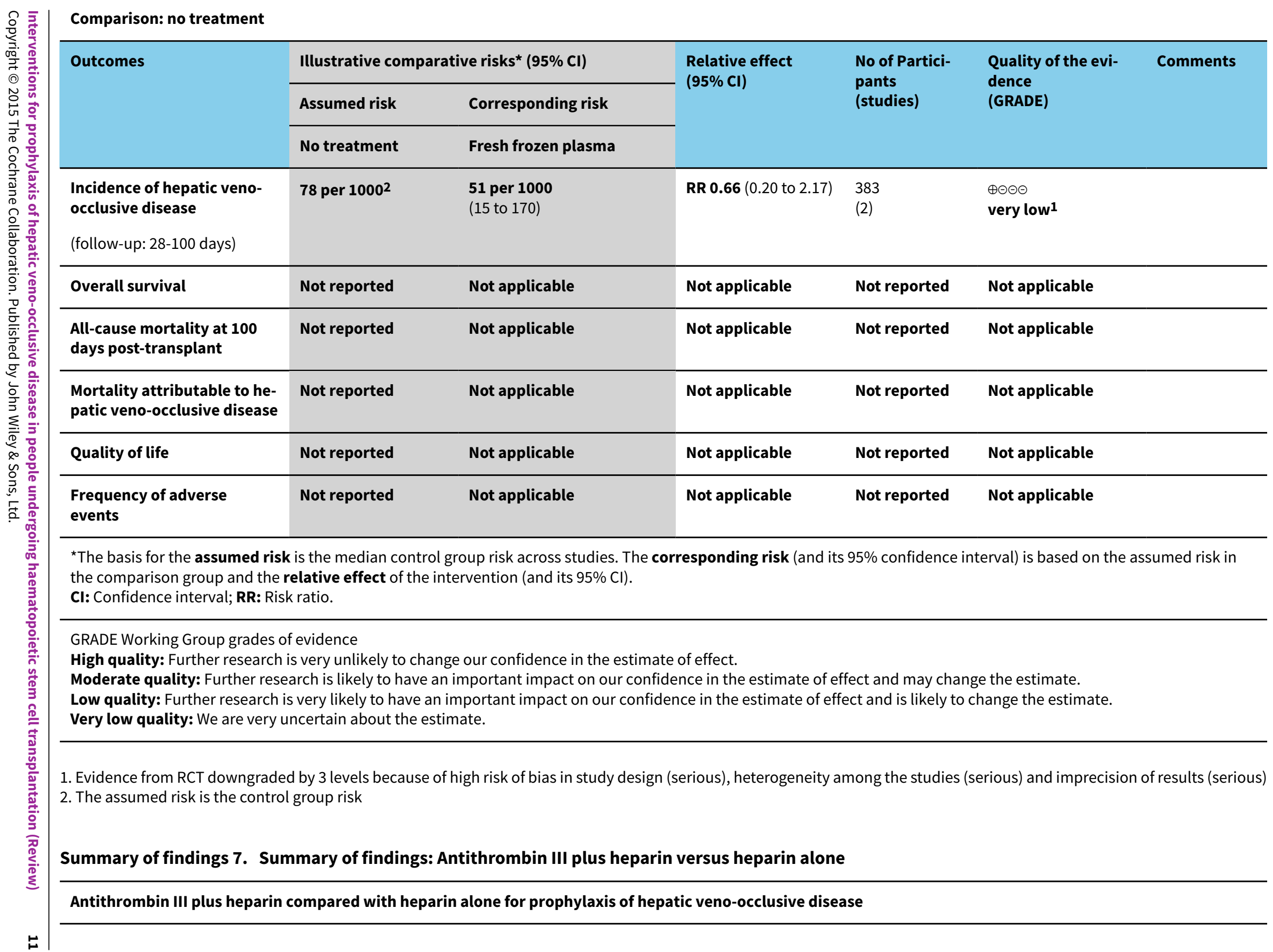


Settings: Inpatients

Intervention: Antithrombin III plus heparin

Comparison: Heparin alone

\begin{tabular}{|c|c|c|c|c|c|c|}
\hline \multirow[t]{3}{*}{ Outcomes } & \multicolumn{2}{|c|}{ Illustrative comparative risks ${ }^{\star}(95 \% \mathrm{Cl})$} & \multirow{3}{*}{$\begin{array}{l}\text { Relative effect } \\
(95 \% \mathrm{Cl})\end{array}$} & \multirow{3}{*}{$\begin{array}{l}\text { No of Partici- } \\
\text { pants } \\
\text { (studies) }\end{array}$} & \multirow{3}{*}{$\begin{array}{l}\text { Quality of the } \\
\text { evidence } \\
\text { (GRADE) }\end{array}$} & \multirow[t]{3}{*}{ Comments } \\
\hline & Assumed risk & Corresponding risk & & & & \\
\hline & Heparin alone & $\begin{array}{l}\text { Antithrombin III plus he- } \\
\text { parin }\end{array}$ & & & & \\
\hline $\begin{array}{l}\text { Incidence of hepatic veno-occlusive } \\
\text { disease } \\
\text { (follow-up: unclear) }\end{array}$ & 250 per $1000^{2}$ & $\begin{array}{l}33 \text { per } 1000 \\
(2 \text { to } 538)\end{array}$ & $\begin{array}{l}\text { RR } 0.13 \text { (0.01 to } \\
2.15)\end{array}$ & $\begin{array}{l}30 \\
(1)\end{array}$ & $\begin{array}{l}\oplus \ominus \odot \ominus \\
\text { very low } 1\end{array}$ & \\
\hline Overall survival & Not reported & Not applicable & Not applicable & Not reported & Not applicable & \\
\hline $\begin{array}{l}\text { All-cause mortality at } 100 \text { days post- } \\
\text { transplant }\end{array}$ & Not reported & Not applicable & Not applicable & Not reported & Not applicable & \\
\hline $\begin{array}{l}\text { Mortality attributable to hepatic } \\
\text { veno-occlusive disease } \\
\text { (follow-up: unclear) }\end{array}$ & 0 per $1000^{2}$ & 0 per 1000 & RR not estimable & $\begin{array}{l}30 \\
(1)\end{array}$ & $\begin{array}{l}\oplus \ominus \ominus \ominus \\
\text { very low }\end{array}$ & $\begin{array}{l}\text { No participant } \\
\text { died of hepat- } \\
\text { ic veno-occlu- } \\
\text { sive disease in } \\
\text { either the treat- } \\
\text { ment or control } \\
\text { groups }\end{array}$ \\
\hline Quality of life & Not reported & Not applicable & Not applicable & Not reported & Not applicable & \\
\hline $\begin{array}{l}\text { Frequency of adverse events } \\
\text { (follow-up: unclear) }\end{array}$ & 250 per $1000^{2}$ & $\begin{array}{l}73 \text { per } 1000 \\
(10 \text { to } 568)\end{array}$ & $\begin{array}{l}\text { RR } 0.29 \text { (0.04 to } \\
2.27)\end{array}$ & $\begin{array}{l}30 \\
(1)\end{array}$ & $\begin{array}{l}\oplus \ominus \ominus \ominus \\
\text { very low } 1\end{array}$ & \\
\hline
\end{tabular}

*The basis for the assumed risk is the control group risk. The corresponding risk (and its $95 \%$ confidence interval) is based on the assumed risk in the comparison group and the relative effect of the intervention (and its $95 \% \mathrm{Cl}$ ).

Cl: Confidence interval; RR: Risk ratio.

GRADE Working Group grades of evidence

High quality: Further research is very unlikely to change our confidence in the estimate of effect.

Moderate quality: Further research is likely to have an important impact on our confidence in the estimate of effect and may change the estimate. 


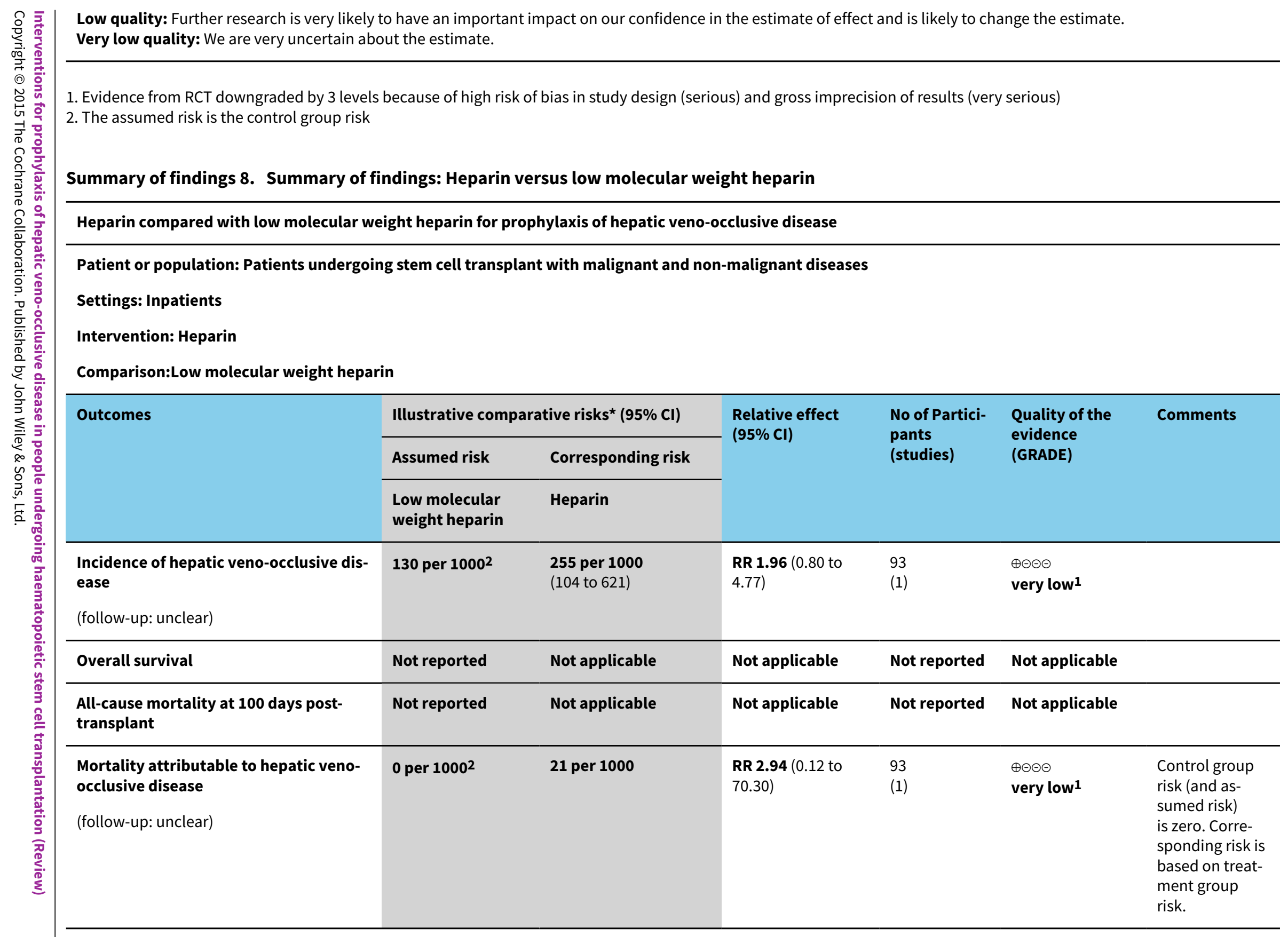




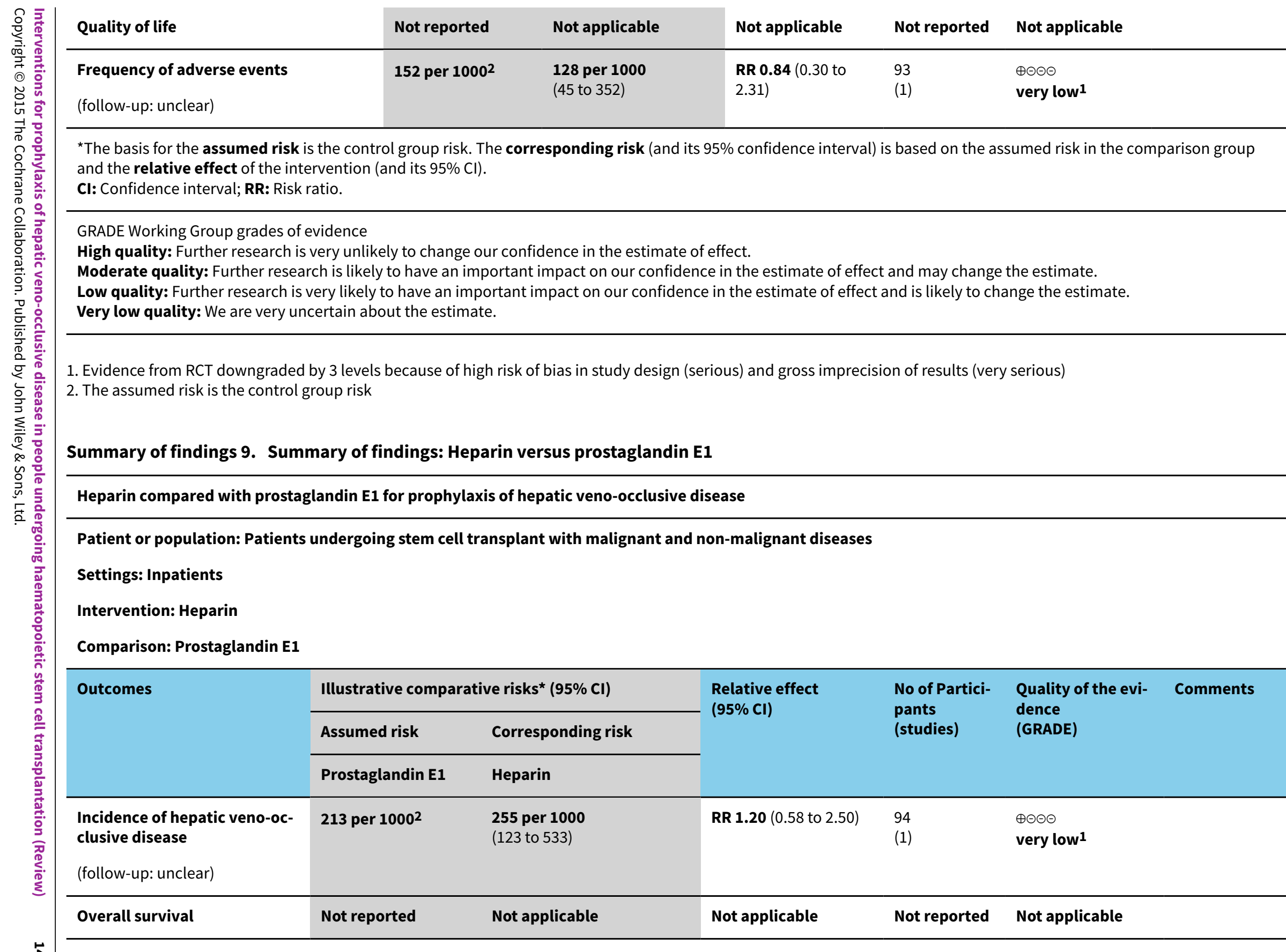




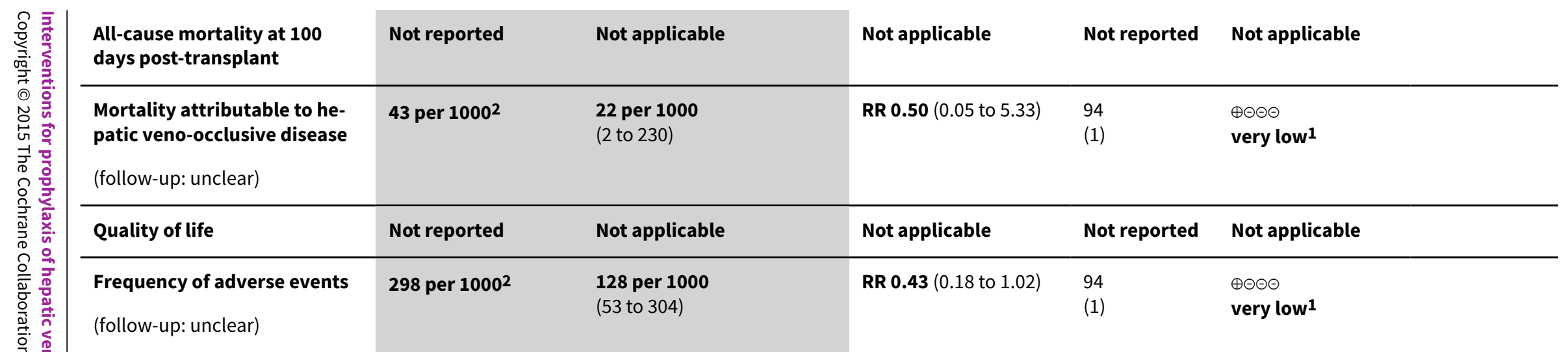

*The basis for the assumed risk is the control group risk. The corresponding risk (and its $95 \%$ confidence interval) is based on the assumed risk in the comparison group and the relative effect of the intervention (and its $95 \% \mathrm{Cl}$ ).

Cl: Confidence interval; RR: Risk ratio.

GRADE Working Group grades of evidence

High quality: Further research is very unlikely to change our confidence in the estimate of effect.

Moderate quality: Further research is likely to have an important impact on our confidence in the estimate of effect and may change the estimate.

Low quality: Further research is very likely to have an important impact on our confidence in the estimate of effect and is likely to change the estimate.

Very low quality: We are very uncertain about the estimate.

1. Evidence from RCT downgraded by 3 levels because of high risk of bias in study design (serious) and gross imprecision of results (very serious)

2. The assumed risk is the control group risk

\section{Summary of findings 10. Summary of findings: Low molecular weight heparin versus prostaglandin E1}

Low molecular weight heparin compared with prostaglandin E1 for prophylaxis of hepatic veno-occlusive disease

Patient or population: People undergoing stem cell transplant with malignant and non-malignant diseases

Settings: Inpatients

Intervention: Low molecular weight heparin

Comparison: Prostaglandin E1

\begin{tabular}{|c|c|c|c|c|c|c|}
\hline \multirow[t]{2}{*}{ Outcomes } & Illustrative col & ve risks* $(95 \% \mathrm{Cl})$ & \multirow{2}{*}{$\begin{array}{l}\text { Relative effect } \\
(95 \% \mathrm{CI})\end{array}$} & \multirow{2}{*}{$\begin{array}{l}\text { No of Partici- } \\
\text { pants } \\
\text { (studies) }\end{array}$} & \multirow{2}{*}{$\begin{array}{l}\text { Quality of the evi- } \\
\text { dence } \\
\text { (GRADE) }\end{array}$} & \multirow[t]{2}{*}{ Comments } \\
\hline & Assumed risk & Corresponding risk & & & & \\
\hline
\end{tabular}




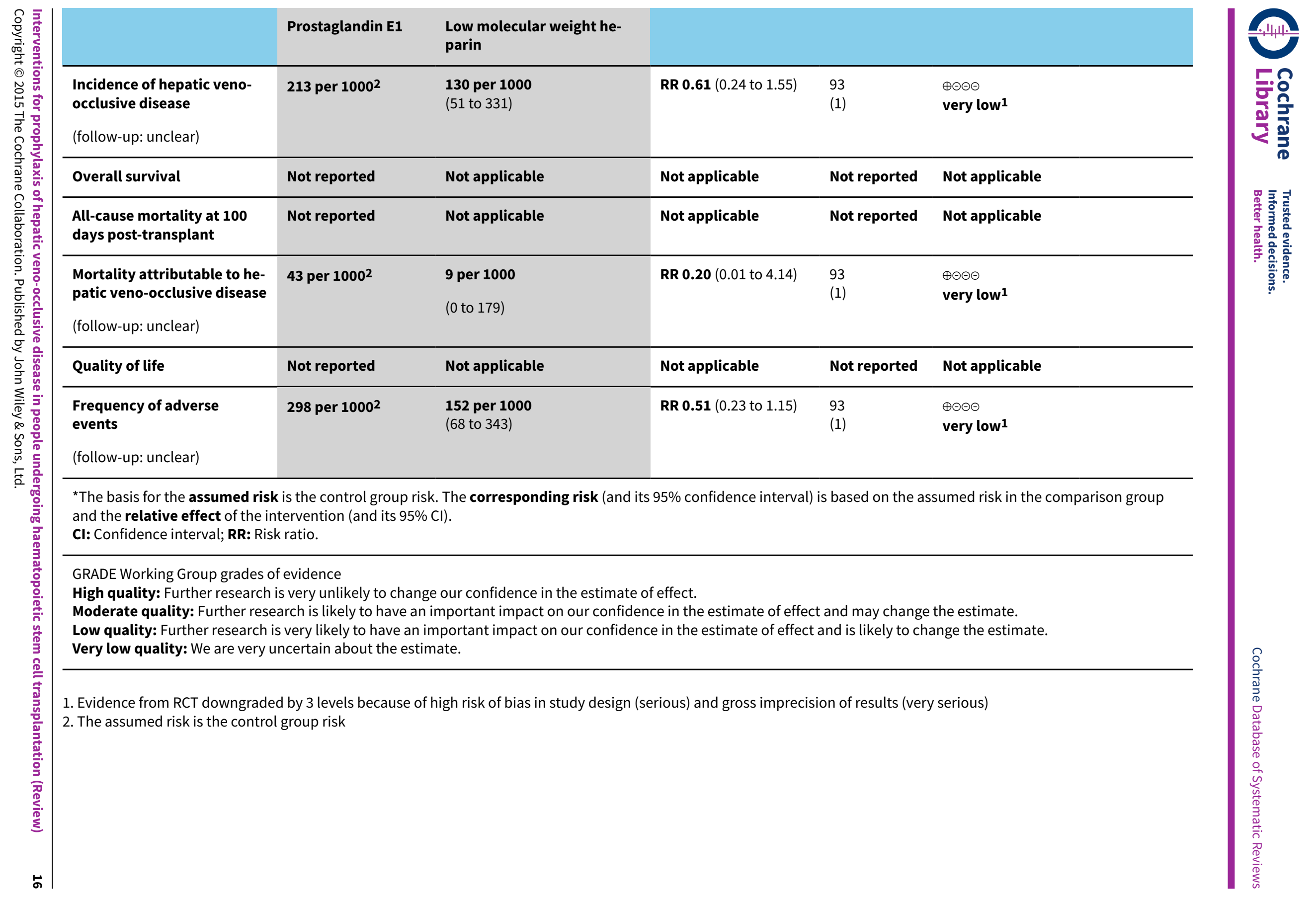




\section{B A C K G R O U N D}

\section{Description of the condition}

Haematopoietic stem cell transplantation (HSCT) is an important treatment for many different malignant and non-malignant diseases. However, it is associated with various complications which may result in death. Hepatic veno-occlusive disease (VOD), also known as hepatic sinusoidal obstruction syndrome, is one of the major complications of HSCT and is the leading cause of transplant-related mortality. Up to $77 \%$ of transplant recipients develop VOD after HSCT when prophylaxis is not given (Coppell 2010), with mortality of around $84 \%$ in severe cases despite treatment (Coppell 2010). It can occur following both autologous and allogeneic HSCT, regardless of the stem cell source, type of conditioning, or underlying disease.

Diagnosis of hepatic VOD is based on a constellation of symptoms and signs and serum bilirubin level. The most commonly used diagnostic criteria for hepatic VOD include the Seattle criteria (McDonald 1984), the modified Seattle criteria (McDonald 1993), and the Baltimore criteria (Jones 1987). By the Seattle criteria, hepatic VOD is diagnosed when two or more of the three criteria (jaundice, hepatomegaly with right upper quadrant abdominal pain, ascites or unexplained weight gain or both) are fulfilled. The modified Seattle criteria require occurrence of at least two of the following three events within 20 days post-HSCT: total bilirubin $\geq 2$ $\mathrm{mg} / \mathrm{dL}$, hepatomegaly or right upper quadrant abdominal pain of hepatic origin, or unexplained weight gain $>2 \%$ of baseline because of fluid accumulation. The Baltimore criteria require an elevated total bilirubin level ( $\geq 2 \mathrm{mg} / \mathrm{dL}$ ) before day 21 post-HSCT and two of the following three criteria: tender hepatomegaly, weight gain > $5 \%$ from baseline, or ascites. The severity of hepatic VOD is usually categorised into three stages: mild, moderate, or severe, depending on adverse effects from hepatic VOD, treatment required, duration of disease, and mortality (McDonald 1993).

The pathogenesis of hepatic VOD is incompletely understood. The clinical manifestations of hepatic VOD are thought to be caused by sinusoidal obstruction with or without occlusion of intrahepatic central venules, resulting from dysfunction of hepatic sinusoidal endothelial cells (SEC) (DeLeve 2002; Helmy 2006). The cause of SEC dysfunction is multifactorial. Many different risk factors for hepatic VOD have been described. Conditioning with busulfan with or without cyclophosphamide (Barker 2003; Cesaro 2005; Cheuk 2007; Lee 2010; McDonald 1993; Song 2006) or conditioning with total body irradiation (Hasegawa 1998; Lee 2010) are reported to be significant risk factors for hepatic VOD. Busulfan has high inter-patient variability in pharmacokinetics and increased exposure correlates with increased risk of hepatic VOD (Krivoy 2008). Metabolites of busulfan or irradiation may deplete the cellular pool of glutathione, which is an essential antioxidant that protects hepatocytes and SEC from free radical damage (Helmy 2006; McDonald 1993). Irradiation also increases tumour necrosis factor alpha, which causes increased capillary permeability and contributes to SEC and hepatocyte dysfunction (Bearman 1995; Hallahan 1989). People of extreme age may have a higher risk of developing hepatic VOD. The reasons are uncertain. In children, the smaller calibre of hepatic venules and relatively high busulfan concentration may predispose them to develop hepatic VOD (Cesaro 2005; Cheuk 2007; Horn 2002). In the elderly, pre-existing hepatic dysfunction and poorer tolerance to hepatotoxic medications may increase their risk of developing hepatic VOD (McDonald 1984; Toh 1999). Transplant for thalassaemia major (Cheuk 2007) may also carry a higher risk for hepatic VOD development. In people with thalassaemia, the pre-existing iron overload and liver dysfunction may predispose them to develop hepatic VOD when additional insults occur, such as a busulfan-containing conditioning regimen (Cheuk 2007). Various malignancies, such as acute leukaemia (Ozkaynak 1991), neuroblastoma (Cesaro 2005; Horn 2002), or advanced malignancies (Hasegawa 1998; Reiss 2002) may also carry a higher risk of hepatic VOD compared with most non-malignant conditions (Song 2006), as the cytotoxic chemotherapy may have caused hepatocyte injury directly or indirectly through release of various cytokines (Bearman 1995; Helmy 2006). Allogeneic HSCT using an unrelated donor (Barker 2003; McDonald 1993; Reiss 2002; Simon 2001) or human leukocyte antigen (HLA)-mismatched donor (Hasegawa 1998; McDonald 1993) also increases the risk of hepatic VOD, because the alloimmune T cells may release cytokines that contribute to liver toxicity, particularly when acute graft-versushost disease (GVHD) occurs (Antin 1992; Hasegawa 1998).

Since hepatic VOD can cause significant morbidity and mortality, with some risk factors not modifiable and treatment of established or severe hepatic VOD largely unsuccessful, many transplant centres now administer routine prophylactic therapy to prevent the occurrence of hepatic VOD in transplant recipients, especially in high-risk patients. However, the medications and regimens used are highly variable and no widely accepted recommendation or guideline exists.

\section{Description of the intervention}

Prophylactic medications that have been used for hepatic VOD in transplant recipients include heparin (Batsis 2006; Feldman 1996; Marsa-Vila 1991; Rosenthal 1996; Song 2006), low molecular weight heparin (Forrest 2003; Or 1996; Styler 1996), danaparoid (Sakaguchi 2010), ursodeoxycholic acid (Essell 1992; Thornley 2004), prostaglandin E1 (Gluckman 1990; Song 2006), glutamine (Brown 1998), and defibrotide (Capelli 2009; Chalandon 2004; Corbacioglu 2006; Dignan 2007; Qureshi 2008; Versluys 2004). Some of these have also been tried in combinations (Simon 2001). Prophylaxis is generally given continuously from the commencement of conditioning or the time of stem cell infusion until neutrophil engraftment, or three to four weeks after HSCT, during which hepatic VOD is most likely to develop. Some centres administer hepatic VOD prophylaxis to all people undergoing HSCT, while others will only give prophylaxis for those at high risk, with variable criteria for 'high risk'.

\section{How the intervention might work}

Heparin is an anticoagulant which enhances the action of the natural anticoagulant antithrombin in inhibiting multiple coagulation factors including thrombin, factors VIIa, IXa, Xa, XIa, and XIla. Prophylactic heparin administration is intended to prevent clot formation in hepatic venules, which is part of the pathological changes in hepatic VOD. Heparin prophylaxis was found to be associated with a low incidence of hepatic VOD in some studies (10\% to $20 \%$ ) (Rosenthal 1996; Song 2006). Survival at 100 days post-transplant was as high as $95 \%$ (Song 2006). Mild haemorrhage occurred in $56 \%$ of participants in one study (Rosenthal 1996). Combining heparin with fresh frozen plasma might further reduce the incidence of hepatic VOD to 5.9\% (Batsis 2006). 
Low molecular weight heparin, such as enoxaparin, is a derivative of heparin with a similar mechanism of action. It has the advantage of more predictable and stable anticoagulant effects and thus reduces the need for monitoring. It is injected subcutaneously and does not require continuous intravenous infusion. It is also less likely to cause significant adverse events, such as heparininduced thrombocytopenia or osteoporosis. Its use was found to be associated with a low incidence of hepatic VOD (4\% to 23\%) (Forrest 2003; Simon 2001; Styler 1996). Overall survival at 100 days was $85 \%$ in one study (Forrest 2003). Minor haemorrhage occurred in $60 \%$ of participants and significant haemorrhage occurred in $1 \%$ to $8 \%$ of participants (Forrest 2003; Simon 2001).

Danaparoid is a mixture of low molecular weight heparin, chondroitin sulfate, and dermatan sulfate present in animal gut mucosa. It renders factor $\mathrm{Xa}$ and thrombin inactive without affecting platelet function. It therefore promotes anticoagulation with a lower bleeding tendency than heparin or low molecular weight heparin. It also inhibits inflammatory cytokines (Iba 2008) and may reduce the incidence of hepatic VOD (Sakaguchi 2010). Only $2 \%$ of people developed hepatic VOD and $2 \%$ had significant haemorrhage (Sakaguchi 2010).

Ursodeoxycholic acid is a hydrophilic bile acid which alters the milieu of bile acids by making them less hydrophobic overall. Since retention of hydrophobic bile acids was thought to contribute to hepatocellular injury in cholestatic liver disease, ursodeoxycholic acid might reduce hepatotoxicity induced by hepatotoxic medications used during HSCT. Moreover, ursodeoxycholic acid may attenuate the pro-inflammatory cytokine environment through decreased expression of tumour necrosis factor alpha, interleukin 1, interleukin 2, and interferon gamma, thereby minimising endothelial injury (Yoshikawa 1992). Ursodeoxycholic acid was found to prevent hepatic VOD in some clinical studies (Essell 1992; Thornley 2004). The incidence of hepatic VOD ranged from 3\% to 9\% (Essell 1992; Thornley 2004). The overall survival at four years was $70 \%$ (Thornley 2004). No adverse event was reported.

Prostaglandin E1 is a vasodilator with inhibitory effects on platelet aggregation, which may therefore prevent clotting of the hepatic venules and prevent hepatic VOD from developing or progressing. Some studies showed that continuous prostaglandin E1 administration was associated with reduced incidence of hepatic VOD (Gluckman 1990; Lee 2010; Song 2006). Hepatic VOD occurred in $12 \%$ to $35 \%$ of participants (Gluckman 1990; Song 2006) and survival at 100 days post-transplant was $92 \%$ to $95 \%$ in one study (Song 2006). No adverse effect was reported.

Glutamine is the precursor for production of glutathione, which is an essential antioxidant that protects hepatocytes and endothelial cells from oxidative damage by free radicals and activated chemotherapeutic metabolites (Teicher 1988). Glutamine becomes the rate-limiting factor in the production of glutathione by the liver during periods of catabolic stress. Glutathione depletion is hypothesised to be an essential component in the pathogenesis of hepatic VOD (Helmy 2006). By increasing production of glutathione, glutamine may prevent the development of hepatic VOD. Glutamine supplementation has led to preservation of protein $C$ and albumin levels early in the post-transplant period, which may be associated with a reduced risk of hepatic VOD (Brown 1998). Among 18 participants who received glutamine, none developed hepatic VOD and all survived the initial post-transplant period (Brown 1998). No adverse event was reported.

Defibrotide is a mixture of single-stranded oligonucleotide. It binds to endothelial cells via adenosine receptors $A 1$ and $A 2$ (Bianchi 1993), which may protect endothelial cells in response to injury. It increases endogenous production of prostaglandin 12, prostaglandin E2 (Coccheri 1988), and thrombomodulin (Zhou 1994), which inhibit platelet activities and coagulation. It also decreases thrombin generation and thrombin-induced platelet aggregation (Bracht 1994), and promotes fibrinolysis via upregulation of tissue factor pathway inhibitor (Cella 2001) and tissue plasminogen activator (Falanga 2003; Pasini 1996), reduction of plasminogen activator inhibitor 1 (Falanga 2003; Pasini 1996), and enhancement of plasmin activity (Echart 2009). Some clinical studies found defibrotide to be effective in preventing hepatic VOD, which occurred in $0 \%$ to $11 \%$ of those given prophylaxis (Capelli 2009; Chalandon 2004; Corbacioglu 2006; Dignan 2007; Qureshi 2008; Versluys 2004). Overall survival at 100 days post-transplant ranged from $89 \%$ to $100 \%$ (Chalandon 2004; Corbacioglu 2006; Dignan 2007; Versluys 2004). No adverse event was reported.

\section{Why it is important to do this review}

Hepatic VOD is a severe complication of haematopoietic stem cell transplantation with high mortality and therefore prevention is an obvious priority. However, it remains uncertain whether the aforementioned preventive medications are based on high-quality evidence. It is therefore important to perform a systematic review to ascertain which medications are effective for prevention of hepatic VOD and to assess the quality of evidence. This is essential for the development of clinical guidelines in the future.

\section{O B J E C T IVES}

We aimed to determine the effects of various prophylactic therapies on incidence of hepatic VOD, overall survival, mortality, quality of life (QOL), and the safety of these therapies in people undergoing HSCT.

\section{METHODS}

\section{Criteria for considering studies for this review}

\section{Types of studies}

We only include randomised controlled trials (RCTs) in the review.

\section{Types of participants}

We include people of all ages who were undergoing haematopoietic stem cell transplantation (HSCT) for any indication.

\section{Types of interventions}

We include trials evaluating prophylactic medications for hepatic veno-occlusive disease (VOD) in the review. The interventions might include heparin, low molecular weight heparin, danaparoid, ursodeoxycholic acid, prostaglandin, glutamine, defibrotide, or others. The control interventions could be placebo or no intervention. We also include trials comparing alternative regimens of the same medication or comparing different medications. 


\section{Types of outcome measures}

We have not used the outcomes listed below as criteria for inclusion of studies.

\section{Primary outcomes}

1. Incidence of hepatic VOD (proportion of participants who developed hepatic VOD during the study period)

2. Overall survival (reported as time-to-event data)

\section{Secondary outcomes}

- All-cause mortality (proportion of participants who died) (Mortality reported at different time points are analysed separately)

- Mortality attributable to hepatic VOD (proportion of participants who died due to hepatic VOD during the study period)

- Quality of life (measured by any validated scales at any time point after treatment)

- Frequency of adverse events (proportion of participants who experienced adverse effects) (All adverse events, severe adverse events and specific adverse events are analysed separately)

\section{Search methods for identification of studies}

\section{Electronic searches}

We searched the Cochrane Central Register of Controlled Trials (CENTRAL) (28 January 2015), MEDLINE (OVID, 1966 to 28 January 2015) and EMBASE (OVID, 1980 to 28 January 2015) (Lefebvre 2011). The search strategies for the different electronic databases (using a combination of controlled vocabulary and text word terms) are shown in the appendices: CENTRAL (Appendix 1), MEDLINE (Appendix 2), and EMBASE (Appendix 3).

\section{Searching other resources}

We also searched conference proceedings of the following annual meetings, if not already included in CENTRAL, from 2000 to January 2015:

- American Society of Hematology (ASH);

- American Society for Clinical Oncology (ASCO);

- European Society for Medical Oncology (ESMO).

We also searched:

- the World Health Organization International Clinical Trials Registry Platform (ICTRP) which registers clinical trials from many different countries (apps.who.int/trialsearch) (accessed on 28 January 2015 , using search terms 'veno-occlusive disease' or 'sinusoidal obstruction syndrome');

- the meta-register of controlled trials (www.controlledtrials.com/mrct/) (accessed on 28 January 2015, using search terms 'veno-occlusive disease' or 'sinusoidal obstruction syndrome').

We include articles published only in abstract form if the review authors could be contacted to provide essential details for appraisal and analysis. We searched reference lists of relevant articles. Wecontacted authors of included studies to identify possible unpublished studies. There was no language restriction in the search and inclusion of studies. We considered multiple publications reporting the same group of participants or its subsets as a single study.

\section{Data collection and analysis}

\section{Selection of studies}

Two review authors (DKLC and AKSC) independently reviewed titles and abstracts of references retrieved from the searches and select all potentially relevant studies. The same review authors obtained copies of these articles and reviewed them independently against our pre-defined inclusion criteria (Higgins 2011a). Review authors were not blinded to the names of the trial authors, institutions, or journal of publication. We resolved all disagreements about selection of studies by consensus. We report the flow of studies as per the PRISMA statement in a flow chart, which contains data on the number of records identified through database searching, number of additional records identified through other sources, number of records after duplicates removed, number of records screened, number of records excluded, number of full-text articles examined for eligibility, number of full-text articles excluded with reasons, and numbers of studies included in qualitative and quantitative syntheses.

\section{Data extraction and management}

Two review authors (DKLC and AKSC) independently extracted data from included trials and entered them into a data collection form (Higgins 2011a), resolving all disagreements by consensus. We contacted the authors of included studies to provide essential information that was missing from study reports. We extracted the following data when available:

1. Study methods
a. Randomisation method (including list generation)
b. Method of allocation concealment
c. Blinding method
d. Stratification factor

2. Participants

a. Inclusion/exclusion criteria

b. Number (total/per group)

c. Age and gender distribution

d. Underlying diseases requiring HSCT

e. Previous treatments (chemotherapy, radiotherapy, HSCT)

f. Pre-existing liver dysfunction

g. Previous history of hepatic VOD

h. Performance status before transplant

i. Type of transplant (autologous, allogeneic)

j. Donor (family donor, unrelated donor)

k. Human leukocyte antigen (HLA) disparity

I. Stem cell source (bone marrow, peripheral blood stem cell, cord blood)

m. Stem cell manipulation ( $T$ cell depletion, CD34+ cell selection)

n. Conditioning regimen

o. Graft-versus-host disease (GVHD) prophylaxis 
3. Intervention and control
a. Type of prophylactic intervention
b. Type of control
c. Details of prophylactic regimen and control
d. Details of co-interventions

4. Follow-up data
a. Duration of follow-up
b. Loss to follow-up with reasons

5. Outcome data as described above

6. Analysis data

a. Methods of analysis (intention-to-treat or per-protocol
analysis)

We entered the data into Review Manager 5 (RevMan) (RevMan 2014).

For overall survival data, we estimated the difference between observed and expected event rate (O-E) and its variance from reported event frequencies, as described by Tierney 2007.

\section{Assessment of risk of bias in included studies}

Two review authors (DKLC and AKSC) independently assessed the quality of each eligible trial, resolving all disagreements by consensus.

We included the following items to assess the methodological quality of RCTs in accordance with the Cochrane Handbook for Systematic Reviews of Interventions (Higgins 2011b):

1. Was the allocation sequence adequately generated?

2. Was allocation adequately concealed?

3. Blinding: was knowledge of the allocated interventions adequately prevented during the study?

4. Were incomplete outcome data adequately addressed?

5. Were reports of the study free of suggestion of selective outcome reporting?

6. Was the study apparently free of other problems that could put it at a high risk of bias?

We planned to conduct sensitivity analyses to assess the impact of risk of bias, by including and excluding studies at high risk of bias.

\section{Measures of treatment effect}

We used risk ratio (RR) estimates with 95\% confidence intervals (Cls) for binary outcomes. We used hazard ratio (HR) estimates with $95 \% \mathrm{Cl}$ for time-to-event outcomes. We calculated the number needed to treat for an additional beneficial outcome (NNTB) estimates with $95 \% \mathrm{Cl}$. We used mean difference (MD) estimates with $95 \% \mathrm{Cl}$ for continuous outcome (Deeks 2011). All analyses included all participants in the treatment groups to which they were allocated (intention-to-treat analyses) if data were available.

\section{Dealing with missing data}

We contacted the authors of included studies to supply missing data. We assessed missing data and dropouts for each included study and assessed and discussed the extent to which the results or conclusions of the review could be altered by the missing data (Higgins 2011c). If fewer than $70 \%$ of participants allocated to the treatments were reported on at the end of the trial for a particular outcome, we considered those data to be prone to bias. We did not impute missing data, except that for mortality and incidence of hepatic VOD data we assumed that participants had not died or developed VOD if their data were missing. Meta-analysis of timeto-event data usually requires availability of individual patient data from the original investigators (Higgins 2011a). Otherwise, we used statistical methods according to Tierney 2007.

\section{Assessment of heterogeneity}

We assessed clinical heterogeneity by comparing the distribution of important participant factors between trials (age, underlying diseases, transplant characteristics) and trial factors (randomisation concealment, blinding, losses to follow-up, intervention regimens). We assessed statistical heterogeneity by examining the $I^{2}$ statistic (Deeks 2011), a quantity which describes approximately the proportion of variation in point estimates due to heterogeneity rather than to sampling error. We followed the guide on interpretation of the $I^{2}$ statistic suggested by the Cochrane Handbook for Systematic Reviews of Interventions as follows:

- $0 \%$ to $40 \%$ : may not be important;

- $30 \%$ to $60 \%$ : may represent moderate heterogeneity;

- $50 \%$ to $90 \%$ : may represent substantial heterogeneity;

- $75 \%$ to $100 \%$ : considerable heterogeneity.

In addition, we employed a $\mathrm{Chi}^{2}$ test of homogeneity to determine the strength of evidence that heterogeneity was genuine. If significant heterogeneity $(P<0.1)$ was present, we explored trials to investigate possible explanations.

\section{Assessment of reporting biases}

We had planned to draw funnel plots (estimated differences in treatment effects against their standard errors) if we found sufficient studies (at least 10) for a given outcome. Asymmetry could be due to publication bias, but could also be due to a relationship between trial size and effect size. In the event that we found a relationship, we would have examined clinical diversity of the studies (Sterne 2011). However, there were fewer than ten studies reporting the same outcome and we therefore did not draw a funnel plot.

\section{Data synthesis}

Where the interventions were the same or similar enough, we synthesised results in a meta-analysis if there was no important clinical heterogeneity. We used the Review Manager 5 software (RevMan 2014) to perform meta-analyses using a fixed-effect model (the generic inverse variance method for continuous data outcomes and the Mantel-Haenszel method for dichotomous data outcomes) (Deeks 2011). For multi-arm studies, we conducted analyses of pair-wise comparisons. For meta-analyses, we did not combine the results from participants of the same study into the same meta-analysis more than once to avoid double counting. There was also no arbitrary omission of relevant groups. We produced 'Summary of findings' tables according to the recommendations in the Cochrane Handbook (Deeks 2011). These tables summarise the results for the six pre-defined outcomes (incidence of hepatic VOD, overall survival, all-cause mortality, mortality due to hepatic VOD, quality of life, and frequency of adverse events) and provide grading of the quality of evidence according to the GRADE system (GRADEpro 2008; Schünemann 2011). 


\section{Subgroup analysis and investigation of heterogeneity}

If data permitted, we conducted subgroup analyses (Deeks 2011) for:

1. Different age groups (younger than 12 years, 12 to 18 years, 18 to 60 years, older than 60 years);

2. Different types of underlying diseases (different disease groups);

3. Different types of transplant (autologous, family donor, unrelated donor);

4. Different HLA parity (HLA-matched, HLA-mismatched);

5. Different transplant conditioning (radiation-based, non-radiation-based, busulfan-containing, non-busulfancontaining).

We defined these subgroups a priori. Participants in these important subgroups might have different susceptibility to hepatic VOD and hence might have different response to prophylactic therapy.

We assessed subgroup differences by examining the $\mathrm{I}^{2}$ statistic and performing a $\mathrm{Chi}^{2}$ test for heterogeneity across subgroup results.

\section{Sensitivity analysis}

We had planned to conduct sensitivity analyses to assess the impact of study quality (Deeks 2011). These would include:
1. All studies;

2. Only those without high risk of bias in any aspect.

However, since all the included studies had a high risk of bias, we did not perform a sensitivity analysis.

For outcomes with substantial heterogeneity, we would also have performed random-effects meta-analysis as a sensitivity analysis.

\section{RES U L T S}

\section{Description of studies}

\section{Results of the search}

The electronic searches retrieved a total of 726 records (89 records from CENTRAL, 500 records from MEDLINE, and 137 records from EMBASE). Searching of Internet sources and conference proceedings retrieved an additional 55 records. After duplicates were removed, 622 records remained and were screened. We obtained 25 full-text records. We excluded one study (Characteristics of excluded studies). Two were ongoing studies (Characteristics of ongoing studies). The remaining 22 records describing 14 studies were included (Characteristics of included studies). The flow of the studies is described in Figure 1. 
Figure 1. Study flow diagram.

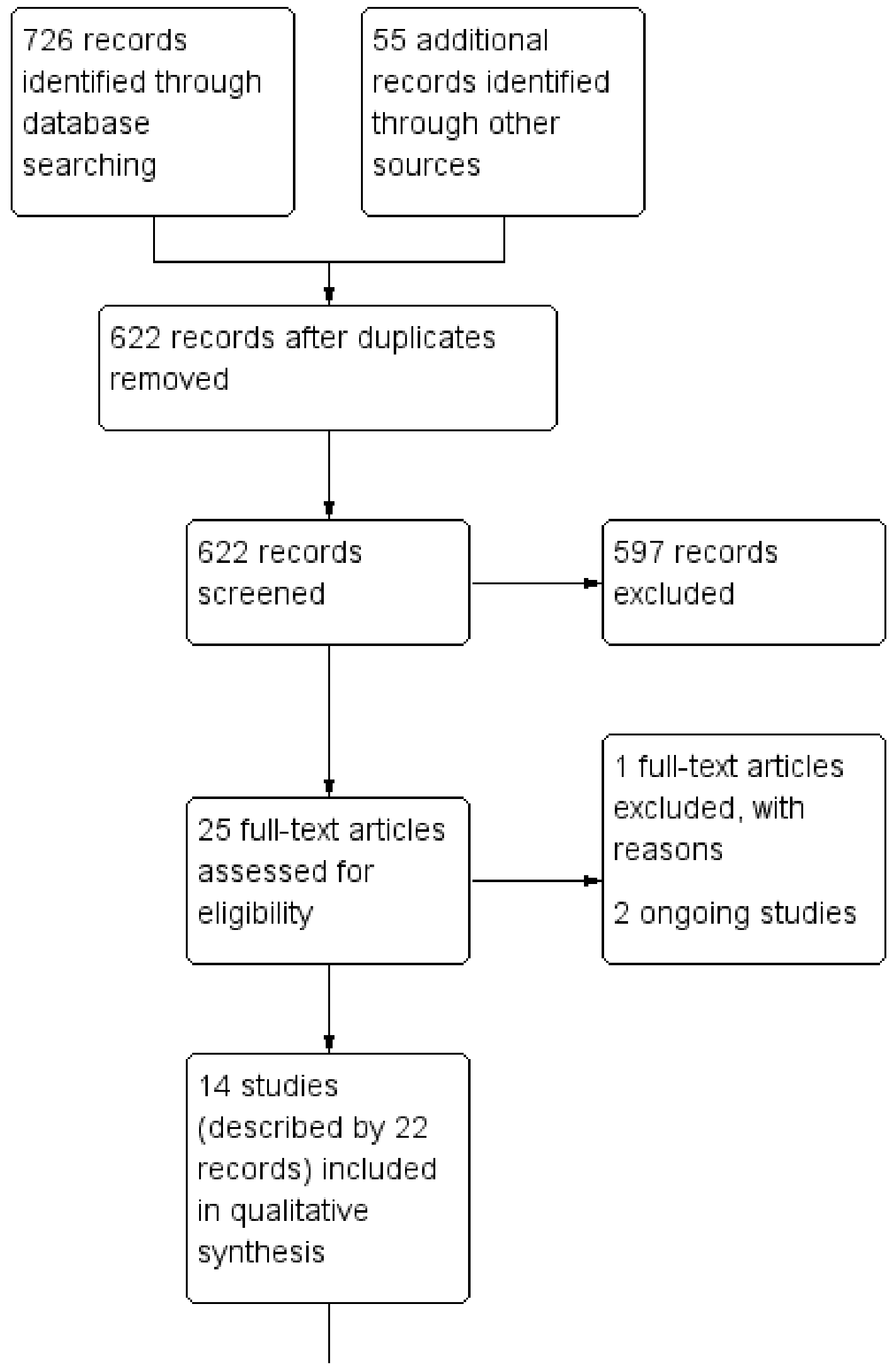


Figure 1. (Continued)

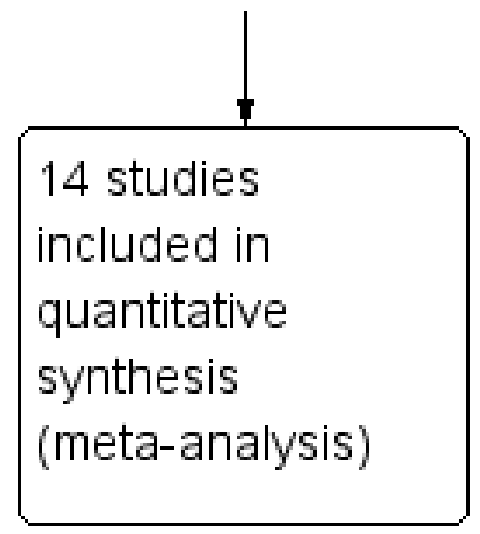

\section{Included studies}

Among the 14 included studies, 10 were published as full papers (Attal 1992; Brown 1998; Corbacioglu 2012; Essell 1998; Marsa-Vila 1991; Matsumoto 2007; Ohashi 2000; Or 1996; Park 2002; Ruutu 2002) and four were published as abstracts only (Demuynck 1995; Jung 2005; Lee 1996; Yannaki 2012). We contacted the authors of all studies for missing information but none provided us with useful results. The characteristics are described in the table of Characteristics of included studies and are summarised below. Two studies each were done in France (Attal 1992; Marsa-Vila 1991), Japan (Matsumoto 2007; Ohashi 2000), and Korea (Jung 2005; Park 2002). One study was done in 28 centres in Europe (Corbacioglu 2012). One study was done in Finland and Sweden (Ruutu 2002). One study each was done in USA (Essell 1998), UK (Brown 1998), Belgium (Demuynck 1995), Greece (Yannaki 2012), Israel (Or 1996), and Singapore (Lee 1996). Two studies were funded by government sources (Marsa-Vila 1991; Matsumoto 2007), one study was supported by a research fund (Or 1996), and two studies were funded by pharmaceutical companies which manufactured defibrotide (Corbacioglu 2012) and ursodeoxycholic acid (Essell 1998) respectively. The funding sources of the other studies were unclear.

\section{Design}

All included studies were parallel-group randomised controlled trials. Thirteen studies had two comparison groups (Attal 1992; Brown 1998; Corbacioglu 2012; Essell 1998; Jung 2005; Lee 1996; Marsa-Vila 1991; Matsumoto 2007; Ohashi 2000; Or 1996; Park 2002; Ruutu 2002; Yannaki 2012) and one study had three comparison groups (Demuynck 1995).

\section{Sample sizes}

The sample size of each included study ranged from 30 to 360 participants. Sample size calculation a priori was performed in six studies (Attal 1992; Corbacioglu 2012; Essell 1998; Ohashi 2000; Park 2002; Ruutu 2002)

\section{Setting}

All studies were carried out in the inpatient setting for people undergoing HSCT.

\section{Participants}

The 14 included studies recruited a total of 1922 participants. All studies included both men and women in similar proportions. Six studies recruited both adults and children aged from one to 64 years (Attal 1992; Brown 1998; Matsumoto 2007; Or 1996; Ruutu 2002; Yannaki 2012), while four studies recruited adults only (aged 18 to 56 years) (Essell 1998; Ohashi 2000; Marsa-Vila 1991; Park 2002) and one study recruited children only (aged 0 to18 years) (Corbacioglu 2012). In three studies, the age distribution of participants was not clear (Demuynck 1995; Jung 2005; Lee 1996). Nine studies recruited participants with a variety of malignant and non-malignant diseases (Attal 1992; Brown 1998; Corbacioglu 2012; Essell 1998; Jung 2005; Matsumoto 2007; Ohashi 2000; Park 2002; Ruutu 2002), while one study recruited only participants with haematological malignancies (Lee 1996) and two studies recruited only participants with haematological malignancies or solid tumours (Marsa-Vila 1991; Or 1996). The participants' underlying diseases were not described in two studies (Demuynck 1995; Yannaki 2012). Only two studies (Essell 1998; Corbacioglu 2012) described treatments that participants received prior to HSCT. Only one study described the performance status prior to HSCT (Essell 1998). Eleven studies recruited both allogeneic and autologous transplant recipients (Attal 1992; Brown 1998; Corbacioglu 2012; Demuynck 1995; Jung 2005; Lee 1996; Ohashi 2000; Or 1996; Park 2002; Ruutu 2002; Yannaki 2012), while two studies recruited only allogeneic transplant recipients (Essell 1998; Matsumoto 2007) and one study recruited only autologous transplant recipients (Marsa-Vila 1991). Stem cell source was bone marrow exclusively in four studies (Attal 1992; Essell 1998; Lee 1996; Marsa-Vila 1991). Either bone marrow or peripheral blood stem cell was used in two studies (Brown 1998; Ruutu 2002); and cord blood was also used in some participants in three studies (Corbacioglu 2012; Jung 2005; Matsumoto 2007). The stem cell source was not described in five studies (Demuynck 1995; Ohashi 2000; Or 1996; Park 2002; Yannaki 2012). A variety of conditioning regimen was used in nine studies (Attal 1992; Brown 1998; Corbacioglu 2012; Matsumoto 2007; Ohashi 2000; Or 1996; Park 2002; Ruutu 2002; Yannaki 2012). Only busulfan and cyclophosphamide were used in one study (Essell 1998). In four studies (Demuynck 1995; Jung 2005; Lee 1996; Marsa-Vila 1991), authors did not describe the conditioning regimen used. Different GVHD prophylaxis was employed in four studies (Corbacioglu 2012; Matsumoto 2007; Ohashi 2000; Ruutu 2002). In two studies (Attal 1992; Essell 1998), all allogeneic transplant recipients received cyclosporin and methotrexate for 
GVHD prophylaxis. In seven studies (Brown 1998; Demuynck 1995; Jung 2005; Lee 1996; Or 1996; Park 2002; Yannaki 2012), GVHD prophylaxis was not described. In one study (Marsa-Vila 1991), only autologous HSCT was performed and GVHD prophylaxis was not applicable. Pre-existing liver dysfunction occurred in some participants in four studies (Attal 1992; Corbacioglu 2012; Essell 1998; Or 1996). This was not described in the remaining ten studies. History of hepatic VOD in participants was described in only one study (Attal 1992).

\section{Interventions}

Four studies investigated the efficacy of ursodeoxycholic acid, with two studies comparing ursodeoxycholic acid with placebo (Essell 1998; Ruutu 2002), one study comparing ursodeoxycholic acid with no treatment (Ohashi 2000), and one study comparing ursodeoxycholic acid plus heparin with heparin alone (Park 2002). The dosing regimen of ursodeoxycholic acid was variable among different trials. One included trial used ursodeoxycholic acid at $300 \mathrm{mg}$ twice daily from 12 to 24 hours before conditioning till discharge or day 30 post-transplant (Park 2002). One trial used $600 \mathrm{mg}$ per day from 21 days before stem cell infusion till day 80 post-transplant (Ohashi 2000). One trial used $6 \mathrm{mg} / \mathrm{kg}$ twice daily from the day of conditioning till day 90 post-transplant (Ruutu 2002). One trial used different doses depending on body weight categories from before the start of conditioning till day 80 post-transplant (Essell 1998). Two studies compared heparin with no treatment (Attal 1992; Marsa-Vila 1991). The first study (Attal 1992) used heparin at 100 units $/ \mathrm{kg} /$ day from the start of conditioning till 30 days post-transplant or discharge. The second study (Marsa-Vila 1991) used heparin at $1 \mathrm{mg} / \mathrm{kg} / \mathrm{day}$ from day 0 to haematological reconstitution and discharge. Two studies investigated the efficacy of low molecular weight heparin, with one study comparing enoxaparin (40 mg daily from one day before stem cell infusion till discharge or day 40 post-transplant) with placebo (Or 1996), and one study comparing nadroparin with no treatment (Lee 1996). One study compared defibrotide $(6.25 \mathrm{mg} /$ $\mathrm{kg} /$ dose every 6 hours from the day of conditioning till day 30 post-transplant) with no treatment (Corbacioglu 2012). One study compared glutamine (50 g daily from the start of conditioning till discharge from the transplant unit) with placebo (Brown 1998). One study compared fresh frozen plasma (FFP) (dosage according to body weight, twice weekly from conditioning till day 28 post- transplant) with no treatment (Matsumoto 2007), and one study compared FFP plus heparin with heparin alone (Yannaki 2012). One study compared antithrombin III (1000 units twice daily from day one till day 14 post-transplant) plus heparin with heparin alone (Jung 2005). The three-arm study compared heparin (100 units/ $\mathrm{kg} /$ day) with enoxaparin ( $20 \mathrm{mg} /$ day) and prostaglandin E1 (PGE1) (500 microgram $/ \mathrm{kg} /$ day) (Demuynck 1995). No trial investigated the effects of danaparoid.

\section{Outcomes}

Thirteen studies reported the incidence of hepatic veno-occlusive disease (VOD) as an outcome measure (Attal 1992; Brown 1998; Corbacioglu 2012; Demuynck 1995; Essell 1998; Jung 2005; Lee 1996; Marsa-Vila 1991; Matsumoto 2007; Ohashi 2000; Park 2002; Ruutu 2002; Yannaki 2012). One study did not report the incidence of hepatic VOD, but frequencies of individual symptom or sign of hepatic VOD in participants, including hyperbilirubinaemia, hepatic enlargement, right upper quadrant abdominal pain, ascites, and weight gain (Or 1996). Five studies reported overall survival (Attal 1992; Corbacioglu 2012; Essell 1998; Park 2002; Ruutu 2002). Six studies reported all-cause mortality (Brown 1998; Corbacioglu 2012; Essell 1998; Ohashi 2000; Park 2002; Ruutu 2002) and nine studies reported mortality attributable to hepatic VOD (Attal 1992; Brown 1998; Corbacioglu 2012; Demuynck 1995; Essell 1998; Jung 2005; Ohashi 2000; Park 2002; Ruutu 2002). None of the 14 included studies reported quality of life of participants. Eleven studies reported adverse events (Attal 1992; Brown 1998; Corbacioglu 2012; Demuynck 1995; Essell 1998; Jung 2005; Lee 1996; Ohashi 2000; Or 1996; Park 2002; Ruutu 2002), which were mainly bleeding complications.

\section{Excluded studies}

We excluded one study after examining the full text of the published reports (Characteristics of excluded studies). This study was evaluating treatment of hepatic VOD instead of prophylaxis (Carbacioglu 2004).

\section{Risk of bias in included studies}

The distribution of risk of bias in different aspects of the included studies is shown in Figure 2 and Figure 3. 
Figure 2. Risk of bias graph: review authors' judgements about each risk of bias item presented as percentages across all included studies.

Random sequence generation (selection bias)

Allocation concealment (selection bias)

Blinding of participants and personnel (performance bias)

Blinding of outcome assessment (detection bias)

Incomplete outcome data (attrition bias)

Selective reporting (reporting bias)

Other bias

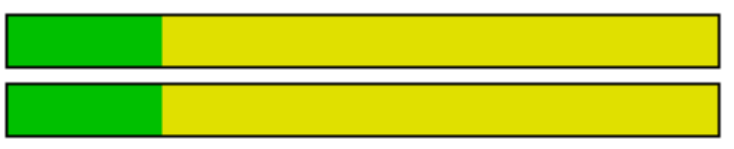

L

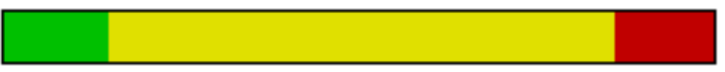

$$
\text { - }
$$

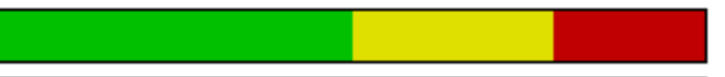

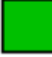

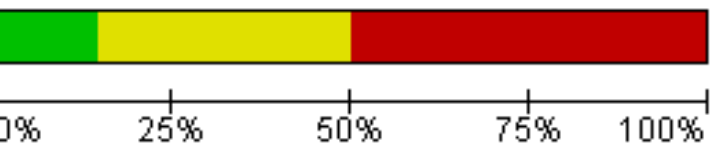

$\begin{array}{lllll}0 \% & 25 \% & 50 \% & 75 \% & 100 \%\end{array}$

Low risk of bias

Unclear risk of bias

High risk of bias 
Figure 3. Risk of bias summary: review authors' judgements about each risk of bias item for each included study.

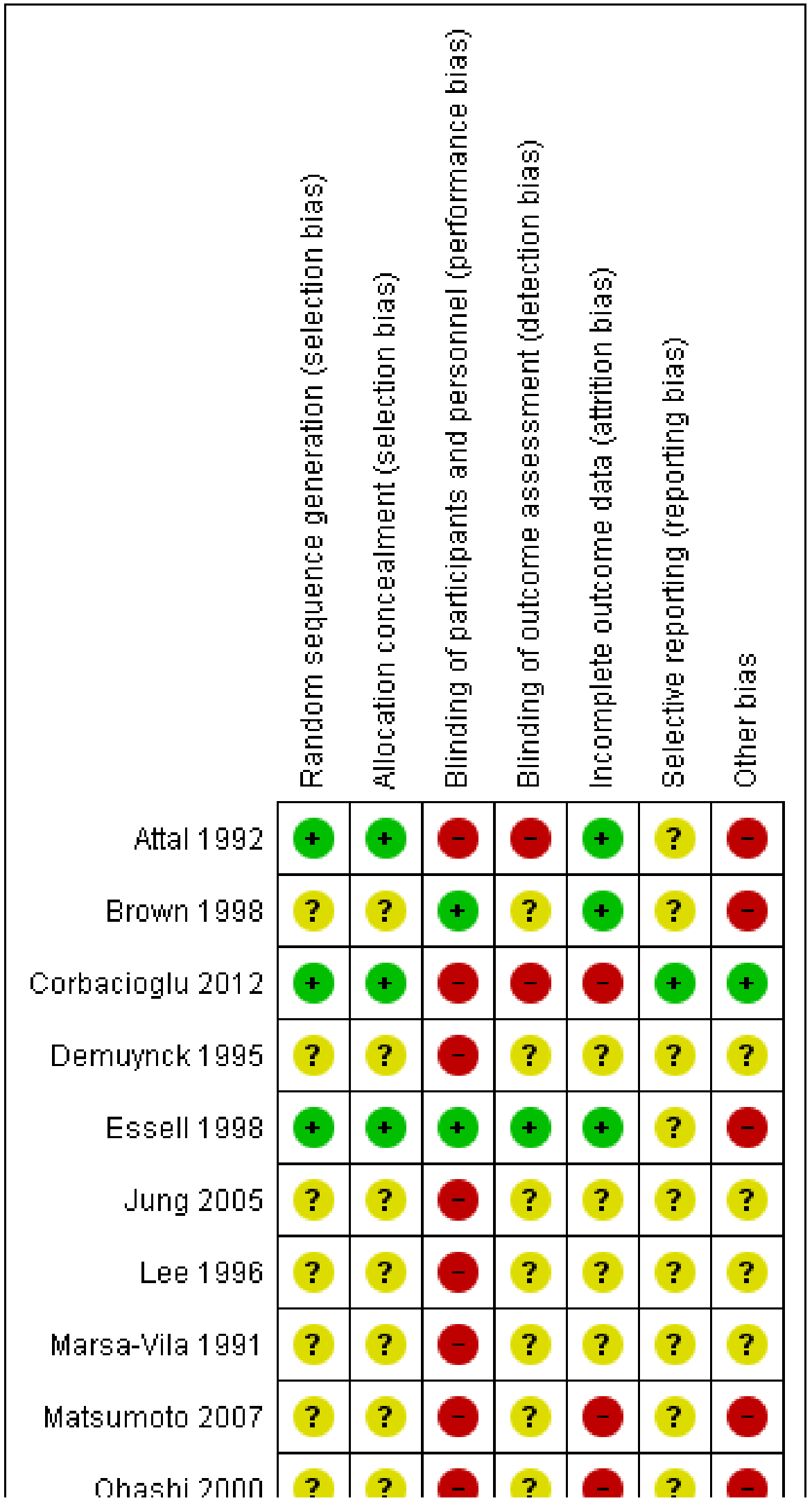

Interventions for prophylaxis of hepatic veno-occlusive disease in people undergoing haematopoietic stem cell transplantation (Review) 
Figure 3. (Continued)

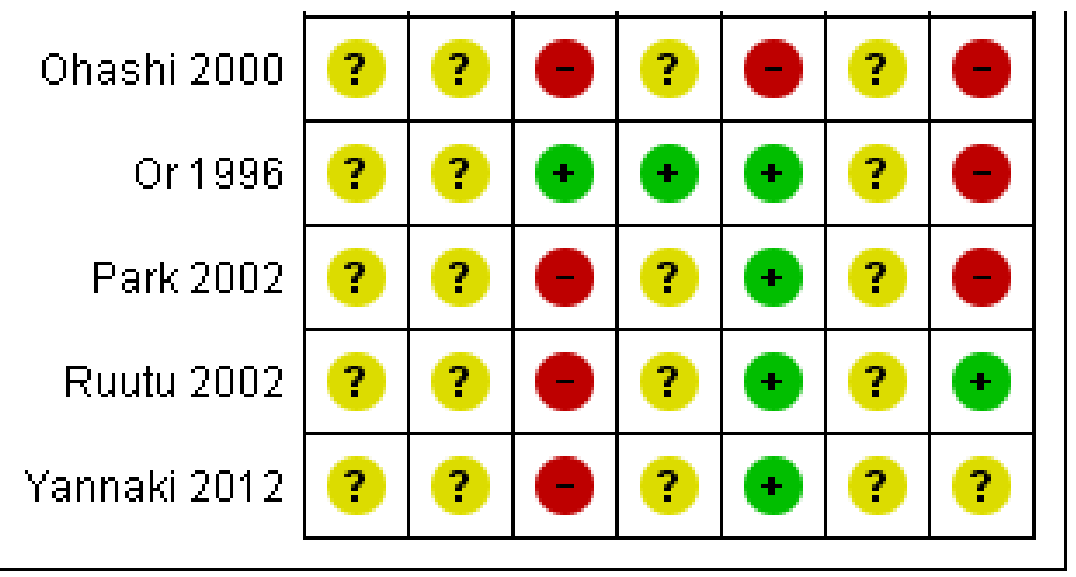

\section{Allocation}

Two studies used computer-generated random sequence for randomisation (Attal 1992; Corbacioglu 2012). The sequence was unknown to study physicians and communicated via telephone (Attal 1992) or managed by a central data manager (Corbacioglu 2012). These were considered adequate randomisation with adequate concealment and at low risk of bias. Another study used randomly assorted allocation cards stored in sealed, opaque, numbered envelops and that was also considered at low risk of bias (Essell 1998). The other studies did not describe random sequence generation or allocation concealment and were therefore considered to have unclear risk of bias (Brown 1998; Demuynck 1995; Jung 2005; Lee 1996; Marsa-Vila 1991; Matsumoto 2007; Ohashi 2000; Or 1996; Park 2002; Ruutu 2002; Yannaki 2012).

\section{Blinding}

Participants, study personnel and outcome assessors were blinded to treatment allocation in two studies (Essell 1998; Or 1996). These were considered to have low risk of bias. Participants and study personnel were also blinded in another study (Brown 1998), but it was unclear whether outcome assessors were also blinded in this study. The other studies did not attempt to blind either the participants or study personnel and therefore were considered to have high risk of bias (Attal 1992; Corbacioglu 2012; Demuynck 1995; Jung 2005; Lee 1996; Marsa-Vila 1991; Matsumoto 2007; Ohashi 2000; Park 2002; Ruutu 2002; Yannaki 2012). Outcome assessors were also not blinded in two of these studies (Attal 1992; Corbacioglu 2012). It was unclear whether outcome assessors for the remaining nine studies were blinded or not (Demuynck 1995; Jung 2005; Lee 1996; Marsa-Vila 1991; Matsumoto 2007; Ohashi 2000; Park 2002; Ruutu 2002; Yannaki 2012).

\section{Incomplete outcome data}

Outcome data were complete in five studies (Attal 1992; Brown 1998; Or 1996; Park 2002; Yannaki 2012). Dropouts occurred in only one participant in one study (Essell 1998), and one participant each in treatment and control groups in another study (Ruutu 2002). These were considered unlikely to cause attrition bias. Dropouts occurred in more than $30 \%$ of participants in one study which were considered to have high risk of bias (Corbacioglu 2012). In two other studies, the dropouts were uneven among the treatment and control groups and were considered to have high risk of bias (Matsumoto 2007; Ohashi 2000). Dropouts were not described in the remaining studies (Demuynck 1995; Jung 2005; Lee 1996; Marsa-Vila 1991) and the risk of bias was unclear.

\section{Selective reporting}

The trial protocols were not available for most included studies to judge whether there might have been selective reporting of outcomes (Attal 1992; Brown 1998; Demuynck 1995; Essell 1998; Jung 2005; Lee 1996; Marsa-Vila 1991; Matsumoto 2007; Ohashi 2000; Or 1996; Park 2002; Ruutu 2002; Yannaki 2012). These studies were therefore considered to have unclear risk of bias in this respect. One study (Corbacioglu 2012) was registered with a brief protocol available and all relevant outcomes were reported and hence considered to have low risk of bias.

\section{Other potential sources of bias}

In one study (Attal 1992), diagnostic criteria or diagnostic evaluation for hepatic VOD was not uniformly applied to all participants and therefore might cause bias. In seven studies (Attal 1992; Brown 1998; Essell 1998; Matsumoto 2007; Ohashi 2000; Or 1996; Park 2002), some of the baseline characteristics of the treatment and the control groups were not comparable and might introduce bias. In five studies (Demuynck 1995; Jung 2005; Lee 1996; Marsa-Vila 1991; Yannaki 2012), information was not available to judge whether the baseline characteristics of the treatment and the control groups were comparable. In three studies (Brown 1998; Essell 1998; Matsumoto 2007), co-interventions were different between the treatment and the control groups and this might introduce bias. In five studies (Demuynck 1995; Jung 2005; Lee 1996; Marsa-Vila 1991; Yannaki 2012), information was not available to judge whether co-intervention was comparable between the treatment and the control groups.

\section{Effects of interventions}

See: Summary of findings for the main comparison Summary of findings: Ursodeoxycholic acid versus placebo or no treatment; Summary of findings 2 Summary of findings: Heparin versus no treatment; Summary of findings 3 Summary of findings: Low molecular weight heparin versus placebo or no treatment; Summary of findings 4 Summary of findings: Defibrotide versus no treatment; Summary of findings $\mathbf{5}$ Summary of findings: Glutamine versus placebo; Summary of findings 6 Summary of findings: Fresh frozen plasma versus no treatment; Summary of findings 7 Summary of findings: Antithrombin III plus heparin

Interventions for prophylaxis of hepatic veno-occlusive disease in people undergoing haematopoietic stem cell transplantation (Review) $\mathbf{2 7}$ Copyright $\odot 2015$ The Cochrane Collaboration. Published by John Wiley \& Sons, Ltd. 
versus heparin alone; Summary of findings 8 Summary of findings: Heparin versus low molecular weight heparin; Summary of findings 9 Summary of findings: Heparin versus prostaglandin E1; Summary of findings 10 Summary of findings: Low molecular weight heparin versus prostaglandin E1

All data presented were extracted from published reports.

\section{Comparison 1: Ursodeoxycholic acid versus placebo or no treatment}

Two included trials compared ursodeoxycholic acid with placebo (Essell 1998; Ruutu 2002). One trial compared ursodeoxycholic acid with no treatment (Ohashi 2000) and one trial compared ursodeoxycholic acid plus heparin with heparin alone (Park 2002). We analysed these four trials with 612 participants together under this comparison.

\section{Primary outcomes}

Incidence of hepatic VOD

Four included studies (Essell 1998; Ohashi 2000; Park 2002; Ruutu 2002) reported this outcome. One study (Essell 1998) had one participant absent from the control group, one study (Ohashi 2000) had four participants absent from the treatment group, one study (Ruutu 2002) had one participant each in the treatment and the control group dropped out or with missing data, and they were assumed not to have developed hepatic VOD. The pooled result showed that ursodeoxycholic acid reduced the risk of development of hepatic VOD compared to control treatment (risk ratio (RR) 0.60 , $95 \%$ confidence interval $(\mathrm{Cl}) 0.40$ to $0.88, \mathrm{P}=0.01,4$ trials with 612 participants) (Analysis 1.1; Figure 4). The number needed to treat for an additional beneficial outcome (NNTB) was $15(95 \% \mathrm{Cl}$ 7 to 50). However, there was substantial heterogeneity among the studies in this outcome $\left(\mathrm{I}^{2}=59 \%\right.$; $\mathrm{Chi}^{2}$ test $\left.\mathrm{P}=0.06\right)$, which might be related to differences in the participants and the treatment regimen. The missing data might also result in bias of the result. As a sensitivity analysis, a random-effects meta-analysis showed there was no evidence of a difference in the incidence of hepatic VOD between ursodeoxycholic acid and control treatment (RR 0.55, 95\% $\mathrm{Cl} 0.28$ to $1.08, \mathrm{P}=0.08)$.

Figure 4. Forest plot of comparison: 1 Ursodeoxycholic acid versus placebo or no treatment, outcome: 1.1 Incidence of hepatic VOD.

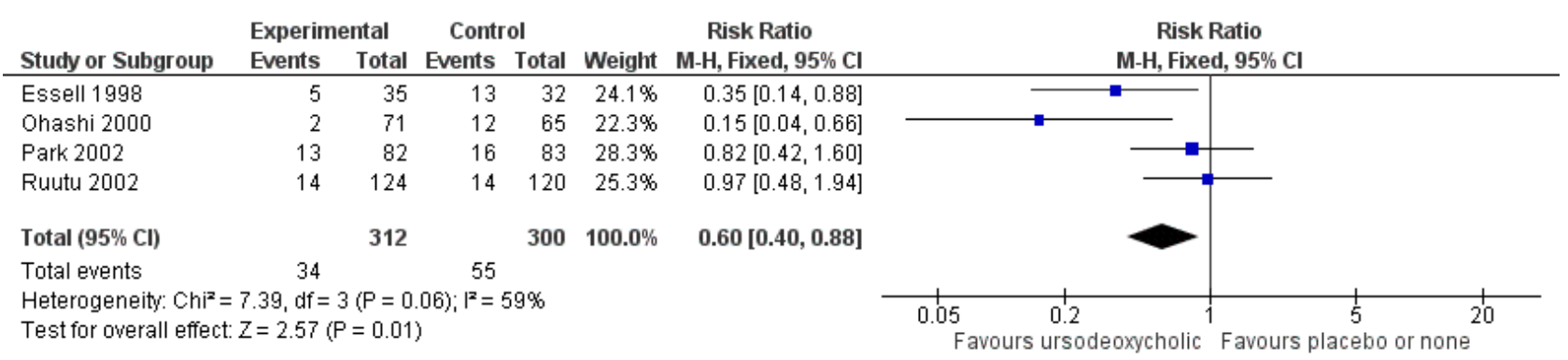

\section{Overall survival}

The pooled result of three studies (Essell 1998; Park 2002; Ruutu 2002) showed no significant difference in overall survival between the treatment and the control groups (hazard ratio (HR) 0.83, 95\% $\mathrm{Cl} 0.59$ to $1.18, \mathrm{P}=0.30,3$ of 4 trials with $77.5 \%$ of participants) (Analysis 1.2). There was moderate heterogeneity among the trials in this outcome $\left(\mathrm{I}^{2}=33 \%, \mathrm{Chi}^{2}\right.$ test $\left.\mathrm{P}=0.22\right)$. One study (Ruutu 2002) had one participant in the treatment group who died and one participant in the control group who dropped out, and were excluded from the survival data. One study did not provide sufficient information to be included in the meta-analysis on overall survival (Ohashi 2000). However, this study commented that the survival curves did not differ significantly between the treatment and the control groups.

\section{Secondary outcomes}

\section{All-cause mortality}

All four included studies (Essell 1998; Ohashi 2000; Park 2002; Ruutu 2002) reported all-cause mortality at 100 days post-transplant. One study (Essell 1998) had one participant missing from the control group, one study (Ohashi 2000) had three participants missing from the treatment group and another study (Ruutu 2002) had one participant in the control group dropped out or with missing data, and they were assumed to be surviving. The pooled results showed that ursodeoxycholic acid reduced all-cause mortality at 100 days post-transplant compared to control treatment (RR $0.70,95 \% \mathrm{Cl}$ 0.50 to $0.99, \mathrm{P}=0.04$, all 4 trials with all 612 participants) (Analysis 1.3). The NNTB was 17 (95\% Cl 8 to 431). There was no important heterogeneity among the trials in this outcome $\left(\mathrm{I}^{2}=0 \%, \mathrm{Chi}^{2}\right.$ test $\mathrm{P}$ $=0.46)$. However, the missing data might result in bias of the result.

\section{Mortality attributable to hepatic VOD}

The pooled results of all four studies (Essell 1998; Ohashi 2000; Ruutu 2002; Park 2002) showed that ursodeoxycholic acid reduced mortality attributable to hepatic VOD compared to control treatment (RR $0.27,95 \% \mathrm{Cl} 0.09$ to $0.87, \mathrm{P}=0.03$, all 4 trials with all 612 participants) (Analysis 1.4). The NNTB was 34 (95\% Cl 16 to 220). There was no important heterogeneity among the trials in this outcome $\left(\mathrm{I}^{2}=0 \%, \mathrm{Chi}^{2}\right.$ test $\left.\mathrm{P}=0.81\right)$. One study (Essell 1998) had one participant absent from the control group, one study (Ohashi 2000) had three participants absent from the treatment group and another study (Ruutu 2002) had one participant in the control group dropped out or with missing data, and they were assumed to be surviving. The missing data might result in bias of the result.

\section{Quality of life}

None of the four trials (Essell 1998; Ohashi 2000; Park 2002; Ruutu 2002) reported this outcome. 


\section{Frequency of adverse events}

In three studies (Essell 1998; Ohashi 2000; Ruutu 2002), none of the participants in either the treatment or the control groups experienced any adverse event. Outcomes regarding one participant in the control group in one study (Essell 1998) and two participants in the treatment group in another study (Ohashi 2000) were missing and they were assumed to have no adverse events due to treatment. The missing data might result in bias of the result. In the study comparing ursodeoxycholic acid plus heparin with heparin alone (Park 2002), eight participants in the treatment group and nine participants in the control group experienced bleeding or prolonged activated partial thromboplastin time (APTT) necessitating withdrawal of treatment. There was no significant difference in the frequency of adverse events between the treatment and the control groups (RR $0.90,95 \% \mathrm{Cl} 0.37$ to 2.22 , $\mathrm{P}=0.82,1$ trial with all 165 participants) (Analysis 1.5).

\section{Comparison 2: Heparin versus no treatment}

Two included studies with 259 participants compared heparin alone with no treatment (Attal 1992; Marsa-Vila 1991).

\section{Primary outcomes}

\section{Incidence of hepatic VOD}

The pooled result of the two studies (Attal 1992; Marsa-Vila 1991) showed no significant difference in the incidence of hepatic VOD between the treatment and the control groups (RR $0.47,95 \% \mathrm{Cl}$ 0.18 to $1.26, P=0.13$, both trials with all 259 participants) (Analysis 2.1; Figure 5). There was considerable heterogeneity between the two studies $\left(\mathrm{I}^{2}=80 \%, \mathrm{Chi}^{2}\right.$ test $\left.\mathrm{P}=0.03\right)$, which might be due to differences in participants and the type of transplant performed. As a sensitivity analysis, a random-effects meta-analysis also showed no evidence of a difference in the incidence of hepatic VOD between the treatment and the control groups (RR $0.72,95 \% \mathrm{Cl} 0.04$ to 13.19 , $P=0.82)$.

Figure 5. Forest plot of comparison: 2 Heparin versus no treatment, outcome: 2.1 Incidence of hepatic VOD.

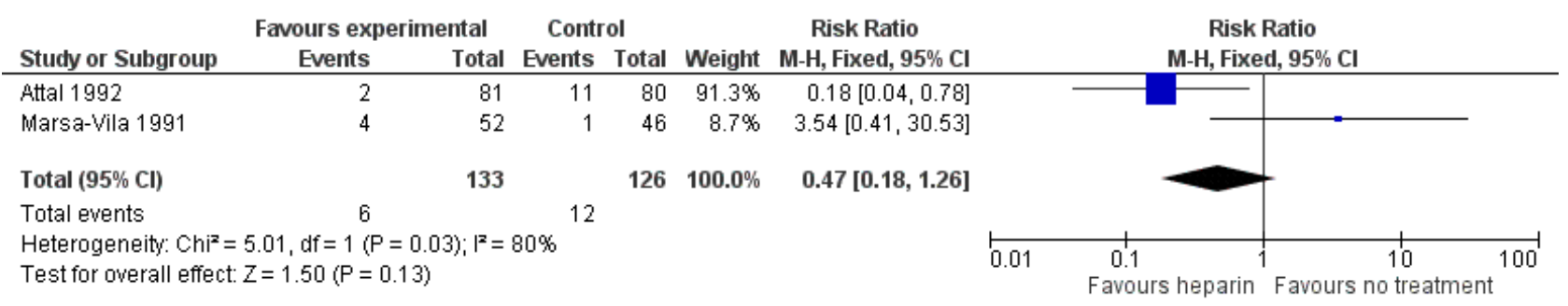

\section{Overall survival}

One study (Attal 1992) with $62.2 \%$ of all participants reported no significant difference in overall survival between the treatment group (92.6\%) and the control group (88.7\%) (Analysis 2.2). However, no sufficient information was available for re-analysis. The other study did not report overall survival (Marsa-Vila 1991).

\section{Secondary outcomes}

\section{All-cause mortality}

One study (Attal 1992) reported all-cause mortality at 100 days post-transplant and showed no significant difference between the treatment and the control groups ( $\mathrm{RR} 0.66,95 \% \mathrm{Cl} 0.25$ to $1.76, \mathrm{P}=$ $0.41,1$ of 2 trials with $62.2 \%$ of all participants) (Analysis 2.3). The other study did not report all-cause mortality (Marsa-Vila 1991).

\section{Mortality attributable to hepatic VOD}

One study (Attal 1992) reported mortality attributable to hepatic VOD and showed no significant difference between the treatment and the control groups (RR $0.28,95 \% \mathrm{Cl} 0.06$ to $1.32, \mathrm{P}=0.11,1$ of 2 trials with $62.2 \%$ of all participants) (Analysis 2.4). The other study did not report this outcome (Marsa-Vila 1991).

\section{Quality of life}

Neither trial (Attal 1992; Marsa-Vila 1991) reported this outcome.

\section{Frequency of adverse events}

One study reported that three participants in the treatment group experienced minor gastrointestinal bleeding (Attal 1992). None of the participants in the control group experienced this. There was no significant difference in the frequency of adverse events between the treatment and the control groups (RR $6.91,95 \% \mathrm{Cl} 0.36$ to $131.75, \mathrm{P}=0.20,1$ of 2 trials with $62.2 \%$ of all participants) (Analysis 2.5). The other study did not report adverse event (Marsa-Vila 1991).

\section{Comparison 3: Low molecular weight heparin versus placebo or no treatment}

Two studies with 106 participants compared low molecular weight heparin with placebo or no treatment, including one study comparing nadroparin with no treatment (Lee 1996) and one study comparing enoxaparin with placebo (Or 1996).

\section{Primary outcomes}

\section{Incidence of hepatic VOD}

One study (Lee 1996) reported no significant difference in the incidence of hepatic VOD between the treatment and the control groups (RR $0.27,95 \% \mathrm{Cl} 0.06$ to $1.18, \mathrm{P}=0.08,1$ of 2 trials with $42.5 \%$ of all participants) (Analysis 3.1). The other study (Or 1996) did not report the incidence of hepatic VOD, but reported frequencies of hyperbilirubinaemia, hepatic enlargement, right upper quadrant abdominal pain, ascites, and weight gain.

\section{Overall survival}

Neither study (Lee 1996; Or 1996) reported overall survival of participants. 


\section{Secondary outcomes}

\section{All-cause mortality}

Neither study (Lee 1996; Or 1996) reported all-cause mortality of participants.

\section{Mortality attributable to hepatic VOD}

Neither study (Lee 1996; Or 1996) reported mortality attributable to hepatic VOD.

\section{Quality of life}

Neither study (Lee 1996; Or 1996) reported quality of life of participants.

\section{Frequency of adverse events}

One study (Or 1996) reported withdrawal of treatment because of bleeding in five participants in the treatment group and eight participants in the control group, which represented no significant difference between the two groups (RR $0.74,95 \% \mathrm{Cl} 0.27$ to 2.00 , $\mathrm{P}=0.55,1$ of 2 trials with $57.5 \%$ of all participants) (Analysis 3.2). The other study stated that there was no increase in haemorrhagic complications in the treatment group compared with the control group, without providing numerical data (Lee 1996).

\section{Comparison 4: Defibrotide versus no treatment}

One included study with 360 participants compared defibrotide with no treatment (Corbacioglu 2012).

\section{Primary outcomes}

\section{Incidence of hepatic VOD}

The included study (Corbacioglu 2012) revealed lower frequency of hepatic VOD in the treatment group (12.2\%) compared with the control group (19.6\%) but the difference was not statistically significant (RR $0.62,95 \% \mathrm{Cl} 0.38$ to $1.02, \mathrm{P}=0.06,1$ trial with all 360 participants) (Analysis 4.1). One participant in the treatment group and three participants in the control group dropped out and were assumed not to have developed VOD. This study also reported subgroup analyses for incidence of hepatic VOD. There was no statistically significant difference in the incidence of hepatic VOD between the treatment and the control groups in infants and children (RR $0.70,95 \% \mathrm{Cl} 0.41$ to $1.19, \mathrm{P}=0.19,1$ trial with $75.8 \%$ of all participants) (Analysis 4.2) or in adolescents (RR $0.35,95 \% \mathrm{Cl}$ 0.10 to $1.22, \mathrm{P}=0.10,1$ trial with $23.1 \%$ of all participants) (Analysis 4.2). There was also no statistically significant difference in the incidence of hepatic VOD between the treatment and the control groups in participants with osteopetrosis (RR $0.21,95 \% \mathrm{Cl} 0.03$ to $1.43, \mathrm{P}=0.11,1$ trial with $3.6 \%$ of all participants) (Analysis 4.3 ) or in participants without osteopetrosis (RR $0.67,95 \% \mathrm{Cl} 0.40$ to $1.11, \mathrm{P}=$ $0.12,1$ trial with $95.3 \%$ of all participants) (Analysis 4.3). There was no statistically significant difference in the incidence of hepatic VOD between the treatment and the control groups in participants who received allogeneic transplant $(\mathrm{RR} 0.58,95 \% \mathrm{Cl} 0.32$ to $1.04, \mathrm{P}=0.07$, 1 trial with $66.4 \%$ of all participants) (Analysis 4.4 ) or in participants who received autologous transplant (RR $0.73,95 \% \mathrm{Cl} 0.30$ to 1.77 , $P=0.43,1$ trial with $30 \%$ of all participants) (Analysis 4.4). There was no evidence of differences in the effects of defibrotide between different age groups $\left(I^{2}=0 \%\right.$, Chi $^{2}$ test $\left.P=0.32\right)$, between the groups with or without osteoporosis $\left(\mathrm{I}^{2}=21.5 \%, \mathrm{Chi}^{2}\right.$ test $\left.\mathrm{P}=0.26\right)$, or between different types of transplants $\left(\mathrm{I}^{2}=0 \%, \mathrm{Chi}^{2}\right.$ test $\left.\mathrm{P}=0.67\right)$

\section{Overall survival}

This study (Corbacioglu 2012) showed no significant difference in the overall survival between the treatment and the control groups ( $\mathrm{HR} 1.04,95 \% \mathrm{Cl} 0.54$ to $2.02, \mathrm{P}=0.90,1$ trial with $98.9 \%$ of all participants) (Analysis 4.5). One participant in the treatment group and three participants in the control group dropped out and were excluded from survival analysis. Many participants had short follow-up and only $48.1 \%$ of participants had outcome data by the end of follow-up at 180 days post-transplant. The missing data might cause bias in the result.

\section{Secondary outcomes}

\section{All-cause mortality}

There was no significant difference in all-cause mortality at 100 days post-transplant between the treatment and the control groups (RR $1.05,95 \% \mathrm{Cl} 0.56$ to $1.97, \mathrm{P}=0.89,1$ trial with all 360 participants) (Analysis 4.6). One participant in the treatment group and three participants in the control group dropped out and were assumed to be surviving.

\section{Mortality attributable to hepatic VOD}

There was no significant difference in mortality attributable to hepatic VOD between the treatment and the control groups (RR $0.40,95 \% \mathrm{Cl} 0.13$ to $1.24, \mathrm{P}=0.11,1$ trial with all 360 participants) (Analysis 4.7). One participant in the treatment group and three participants in the control group dropped out and were assumed to be surviving.

\section{Quality of life}

This study (Corbacioglu 2012) did not report quality of life of participants.

\section{Frequency of adverse events}

This study reported significantly more adverse events related to defibrotide in the treatment group compared with the control group (RR $18.79,95 \% \mathrm{Cl} 1.10$ to $320.45, \mathrm{P}=0.04,1$ trial with all 360 participants) (Analysis 4.8). There were nine adverse events related to defibrotide in the treatment group but no adverse event in the control group. Reported adverse events of participants who had received defibrotide in this study included coagulopathy, gastrointestinal disorders, haemorrhage and microangiopathy. There was no significant difference in the frequency of severe adverse events between the treatment group (three participants) and the control group (no participant) (RR $6.92,95 \% \mathrm{Cl} 0.36$ to $133.07, P=0.20,1$ trial with all 360 participants) (Analysis 4.9). There was also no significant difference in the frequency of haemorrhage between the treatment group (39 participants) and the control group (37 participants) (RR $1.04,95 \% \mathrm{Cl} 0.70$ to $1.55, \mathrm{P}=0.84,1$ trial with all 360 participants) (Analysis 4.10).

\section{Comparison 5: Glutamine versus placebo}

One included study with 34 participants compared glutamine with placebo (Brown 1998).

\section{Primary outcomes Incidence of hepatic VOD}

None of the 34 participants in this study (Brown 1998) developed hepatic VOD. 


\section{Overall survival}

This study (Brown 1998) did not report overall survival of participants.

\section{Secondary outcomes}

\section{All-cause mortality}

There was no significant difference in all-cause mortality at 100 days post-transplant between the treatment and the control groups (RR $0.30,95 \% \mathrm{Cl} 0.01$ to $6.84, \mathrm{P}=0.45,1$ trial with all 34 participants) (Analysis 5.1).

\section{Mortality attributable to hepatic VOD}

There was no death attributable to VOD in this study (Brown 1998).

\section{Quality of life}

This study (Brown 1998) did not report quality of life of participants.

\section{Frequency of adverse events}

One participant who received glutamine had a sensation of abdominal fullness. None of the participants who received placebo experienced an adverse event. There was no significant difference in the frequency of adverse events between the two groups (RR $2.68,95 \% \mathrm{Cl} 0.12$ to $61.58, \mathrm{P}=0.54,1$ trial with all 34 participants) (Analysis 5.2).

\section{Comparison 6: Fresh frozen plasma versus no treatment}

One included study compared fresh frozen plasma with no treatment (Matsumoto 2007) and one study compared fresh frozen plasma plus heparin with heparin alone (Yannaki 2012). We analysed these two trials with 379 participants together.

\section{Primary outcomes}

\section{Incidence of hepatic VOD}

The pooled result of the two included studies (Matsumoto 2007; Yannaki 2012) showed no significant difference in the incidence of hepatic VOD between the treatment and the control groups (RR $0.66,95 \% \mathrm{Cl} 0.20$ to $2.17, \mathrm{P}=0.50,2$ trials of all 379 participants) (Analysis 6.1). There was moderate heterogeneity between the studies in this outcome $\left(I^{2}=47 \%\right.$; $\mathrm{Chi}^{2}$ test $\left.\mathrm{P}=0.17\right)$, which might be related to differences in the participants and the treatment regimen. One study (Matsumoto 2007) had one participant in the treatment group and three participants in the control group dropped out, and they were assumed not to have developed VOD. The missing data might cause bias in the result.

\section{Overall survival}

The included studies (Matsumoto 2007; Yannaki 2012) did not report overall survival of participants.

\section{Secondary outcomes}

\section{All-cause mortality}

The included studies (Matsumoto 2007; Yannaki 2012) did not report all-cause mortality of participants.

\section{Mortality attributable to hepatic VOD}

The included studies (Matsumoto 2007; Yannaki 2012) did not report mortality attributable to hepatic VOD of participants.

\section{Quality of life}

The included studies (Matsumoto 2007; Yannaki 2012) did not report quality of life of participants.

\section{Frequency of adverse events}

The included studies (Matsumoto 2007; Yannaki 2012) did not report adverse events.

\section{Comparison 7: Antithrombin III plus heparin versus heparin alone}

One included study with 30 participants compared antithrombin III plus heparin with heparin alone (Jung 2005).

\section{Primary outcomes}

\section{Incidence of hepatic VOD}

This study (Jung 2005) reported no significant difference in the incidence of hepatic VOD between the treatment and the control groups (RR $0.13,95 \% \mathrm{Cl} 0.01$ to $2.15, \mathrm{P}=0.15,1$ trial with all 30 participants) (Analysis 7.1).

\section{Overall survival}

This study (Jung 2005) did not report overall survival of participants.

\section{Secondary outcomes}

All-cause mortality

This study (Jung 2005) did not report all-cause mortality of participants.

\section{Mortality attributable to hepatic VOD}

None of the participants in this study (Jung 2005) died of hepatic VOD.

\section{Quality of life}

This study (Jung 2005) did not report quality of life of participants.

\section{Frequency of adverse events}

This study (Jung 2005) reported bleeding complications in one participant in the treatment group and four participants in the control group, which represented no significant difference between the two groups ( $\mathrm{RR} 0.29,95 \% \mathrm{Cl} 0.04$ to $2.27, \mathrm{P}=0.24,1$ trial with all 30 participants) (Analysis 7.2).

\section{Comparison 8: Heparin versus low molecular weight heparin}

One included study compared heparin (47 participants) with enoxaparin (46 participants) (Demuynck 1995).

\section{Primary outcomes}

\section{Incidence of hepatic VOD}

This study (Demuynck 1995) reported no significant difference in the incidence of hepatic VOD between the two treatment groups (RR $1.96,95 \% \mathrm{Cl} 0.80$ to $4.77, \mathrm{P}=0.14,1$ trial with 93 participants) (Analysis 8.1).

\section{Overall survival}

This study (Demuynck 1995) did not report overall survival. 


\section{Secondary outcomes}

\section{All-cause mortality}

This study (Demuynck 1995) did not report all-cause mortality of participants.

\section{Mortality attributable to hepatic VOD}

This study (Demuynck 1995) reported no significant difference in mortality attributable to hepatic VOD between the two treatment groups (RR 2.94, 95\% Cl 0.12 to $70.30, \mathrm{P}=0.51,1$ trial with 93 participants) (Analysis 8.2).

\section{Quality of life}

This study (Demuynck 1995) did not report quality of life of participants.

\section{Frequency of adverse events}

This study (Demuynck 1995) reported bleeding complications in six participants in the heparin group and seven participants in the enoxaparin group, which represented no significant difference between the two groups (RR $0.84,95 \% \mathrm{Cl} 0.30$ to $2.31, \mathrm{P}=0.73,1$ trial with 93 participants) (Analysis 8.3).

\section{Comparison 9: Heparin versus prostaglandin E1}

One included study compared heparin (47 participants) with prostaglandin E1 (47 participants) (Demuynck 1995).

\section{Primary outcomes}

\section{Incidence of hepatic VOD}

This study (Demuynck 1995) reported no significant difference in the incidence of hepatic VOD between the two treatment groups (RR $1.20,95 \% \mathrm{Cl} 0.58$ to $2.50, \mathrm{P}=0.63,1$ trial with 94 participants) (Analysis 9.1).

\section{Overall survival}

This study (Demuynck 1995) did not report overall survival.

\section{Secondary outcomes}

All-cause mortality

This study (Demuynck 1995) did not report all-cause mortality of participants.

\section{Mortality attributable to hepatic VOD}

This study (Demuynck 1995) reported no significant difference in mortality attributable to hepatic VOD between the two treatment groups (RR $0.50,95 \% \mathrm{Cl} 0.05$ to $5.33, \mathrm{P}=0.57,1$ trial with 94 participants) (Analysis 9.2).

\section{Quality of life}

This study (Demuynck 1995) did not report quality of life of participants.

\section{Frequency of adverse events}

This study (Demuynck 1995) reported bleeding complications in six participants who received heparin. Fourteen participants who received prostaglandin E1 experienced serious adverse events, including bleeding in two, musculoskeletal pain in six, hypotension in one, and other adverse events in five participants. There was no significant difference in the frequency of adverse events between the two groups (RR $0.43,95 \% \mathrm{Cl} 0.18$ to $1.02, \mathrm{P}=0.06,1$ trial with 94 participants) (Analysis 9.3).

\section{Comparison 10: Low molecular weight heparin versus prostaglandin E1}

One included study compared enoxaparin (46 participants) with prostaglandin E1 (47 participants) (Demuynck 1995).

\section{Primary outcomes}

Incidence of hepatic VOD

This study (Demuynck 1995) reported no significant difference in the incidence of hepatic VOD between the two treatment groups (RR $0.61,95 \% \mathrm{Cl} 0.24$ to $1.55, \mathrm{P}=0.30,1$ trial with 93 participants) (Analysis 10.1).

\section{Overall survival}

This study (Demuynck 1995) did not report overall survival.

\section{Secondary outcomes}

\section{All-cause mortality}

This study (Demuynck 1995) did not report all-cause mortality of participants.

\section{Mortality attributable to hepatic VOD}

This study (Demuynck 1995) reported no significant difference in mortality attributable to hepatic VOD between the two treatment groups (RR $0.20,95 \% \mathrm{Cl} 0.01$ to $4.14, \mathrm{P}=0.30,1$ trial with 93 participants) (Analysis 10.2).

\section{Quality of life}

This study (Demuynck 1995) did not report quality of life of participants.

\section{Frequency of adverse events}

This study reported bleeding complications in seven participants who received enoxaparin. Fourteen participants who received prostaglandin E1 experienced serious adverse events, including bleeding in two, musculoskeletal pain in six, hypotension in one, and other adverse events in five participants. There was no significant difference in the frequency of adverse events between the two groups (RR $0.51,95 \% \mathrm{Cl} 0.23$ to $1.15, \mathrm{P}=0.10,1$ trial with 93 participants) (Analysis 10.3).

\section{Reporting bias}

Since we found fewer than 10 studies for any comparison, we could not reliably assess publication bias and did not produce funnel plots for any outcome.

\section{DISCUSSION}

\section{Summary of main results}

Fourteen randomised controlled trials (RCTs) evaluated prophylactic therapies for hepatic veno-occlusive disease (VOD) in haematopoietic stem cell transplant (HSCT) recipients. Eleven trials compared active treatments with placebo or no treatment, including ursodeoxycholic acid (three trials), heparin (two trials), low molecular weight heparin (two trials), defibrotide (one trial), glutamine (one trial), fresh frozen plasma (one trial), and antithrombin III (one trial). One trial compared ursodeoxycholic

Interventions for prophylaxis of hepatic veno-occlusive disease in people undergoing haematopoietic stem cell transplantation (Review) $\mathbf{3 2}$ Copyright (c) 2015 The Cochrane Collaboration. Published by John Wiley \& Sons, Ltd. 
acid plus heparin with heparin alone and we meta-analysed this trial together with the other three trials on ursodeoxycholic acid. One trial compared fresh frozen plasma plus heparin with heparin alone and we meta-analysed this trial together with the other trial on fresh frozen plasma. One trial compared heparin with low molecular weight heparin and prostaglandin E1 and we conducted pair-wise comparisons.

The results showed that ursodeoxycholic acid, compared with placebo or no treatment, was associated with a reduction in the incidence of hepatic VOD, all-cause mortality, and mortality due to hepatic VOD (four RCTs; 612 participants). However, the estimates of effect size were imprecise with wide confidence intervals. There was also substantial heterogeneity in the primary outcome. Sensitivity analysis by re-analysis of the primary outcome of the incidence of hepatic VOD using a random-effects model showed no significant difference between the treatment and the control groups. All other RCTs on other prophylactic therapies failed to show efficacy in any of the outcomes considered.

In most studies, there was no evidence of a difference between the treatment and the control groups in the frequency of adverse events. One trial showed that participants who received defibrotide had more adverse events compared with the control group who did not receive defibrotide for prophylaxis. However, the estimate of the difference was grossly imprecise. Reported adverse events of defibrotide included coagulopathy, gastrointestinal disorders, haemorrhage and microangiopathy. However, there was no evidence of a difference in the frequency of severe adverse events or haemorrhage.

\section{Overall completeness and applicability of evidence}

Many different prophylactic therapies were tested in RCTs. However, most trials failed to show efficacies of these therapies when compared to placebo or no treatment, including trials on heparin, low molecular weight heparin, glutamine, fresh frozen plasma, and antithrombin III. There was no evidence of differences between Prostaglandin E1, heparin or low molecular weight heparin in any outcomes considered. In the RCT of defibrotide compared with no treatment, there was some discrepancy in the analysis and interpretation of results between the primary study report and our systematic review. The authors of the study used competing risk analysis for the cumulative incidence of hepatic VOD and found that there was a borderline statistically significant difference between the treatment and the control groups, with an absolute risk difference of $7.7 \%$ in favour of the treatment group $(\mathrm{P}=$ 0.0488). However, they reported statistically non-significant results when they analysed the data using the log rank test $(P=0.05)$. Of note is that the authors of the study excluded four randomised participants in their analyses and therefore these analyses were not genuinely intention-to-treat. Our re-analysis based on the published data assuming the four excluded participants did not develop hepatic VOD showed no evidence of a difference in the incidence of hepatic VOD between the treatment group (12.2\%) and the control group (19.6\%). The efficacy, if any, of defibrotide in preventing hepatic VOD appears to be modest, and the benefit was uncertain. The trial might have insufficient statistical power to detect a significant difference between the groups and further large studies are needed to clarify the efficacy of defibrotide for prophylaxis of hepatic VOD.
We found that the only agent that is possibly effective in preventing hepatic VOD in HSCT recipients is ursodeoxycholic acid, which resulted in a relative risk for hepatic VOD of 0.6 , with an absolute risk difference of $7 \%$ and a number needed to treat for an additional beneficial outcome (NNTB) of 15. However, the included studies were small and the effect size estimates were imprecise. There was significant heterogeneity among the included studies in terms of participant characteristics and treatment regimens. Re-analysis of the primary outcome using a random-effects model yielded no significant difference in the incidence of hepatic VOD between the treatment and the control groups, raising further uncertainly about the efficacy of ursodeoxycholic acid. The dosing regimen of ursodeoxycholic acid and the duration of prophylaxis were variable among the trials. It remains uncertain what the optimal regimen may be, and whether ursodeoxycholic acid benefits all HSCT recipients or only certain groups. Moreover, the cost effectiveness of ursodeoxycholic acid as prophylaxis for hepatic VOD remains to be determined.

On the other hand, due to inadequate sample size in the existing trials, the failure to show clinical benefits of many prophylactic regimens may be false negative results. Therefore, the potential benefits of different prophylactic therapies in HSCT recipients cannot be entirely excluded based on the currently available evidence. Further trials of adequate sample size are needed to clarify the role of different prophylactic agents.

In addition, the included trials were of inadequate sample sizes to assess rare adverse events or to determine whether there are genuine differences in the frequency of adverse events among treatment groups.

\section{Quality of the evidence}

Apart from scarcity of RCTs and inadequate statistical power to detect differences between the treatment and the control groups, the trials included in the current review were prone to bias in different aspects. We considered that none of the included studies was at low risk of bias in all aspects assessed. In many included studies, the treatment and the control groups were not comparable at baseline, which casts doubt on the success of randomisation and increases the probability of confounding. Many included studies did not report the random sequence generation or allocation concealment which are important to minimise selection bias. Most included studies failed to blind the participants and personnel which might introduce performance bias. Some trials had significant dropouts and were prone to attrition bias. Trial protocols were not available in most trials and it was uncertain whether there was reporting bias in these RCTs.

\section{Potential biases in the review process}

There are potential biases at both the study level and the review level. The risk of bias at the study level is detailed above in the section Risk of bias in included studies. At the review level, there is possible reporting bias, as we only searched major English electronic databases and therefore non-English literature might be under-represented and missed in the review. Publication bias was also possible. However, the number of included studies was too small for formal evaluation and testing for publication bias. In addition, we only included RCTs in the review and serious or rare adverse events, or both, might have been missed. 


\section{Agreements and disagreements with other studies or reviews}

There is a systematic review on the use of ursodeoxycholic acid for prophylaxis of VOD in HSCT recipients (Tay 2007). This review included four RCTs and two historically controlled studies, with a total of 824 participants. The RCTs included were the same as in our review, with similar conclusions. Ursodeoxycholic acid resulted in a lower incidence of hepatic VOD compared with placebo or no treatment (RR $0.34 ; 95 \% \mathrm{Cl} 0.17$ to $0.66, \mathrm{P}=0.002$, 3 studies). As in our findings, overall survival showed no evidence of a difference between the treatment and the control groups.

There is also a systematic review on the use of anticoagulants for prophylaxis of hepatic VOD in HSCT recipients (Imran 2006). Three RCTs and nine cohort studies with a total of 2782 participants were included in this review. The RCTs included were the same as in our review, and evaluate heparin (two RCTs) or enoxaparin (one RCT). The pooled result of all studies showed no evidence of a difference in the incidence of hepatic VOD between the treatment and the control groups (RR 0.90; $95 \% \mathrm{Cl} 0.62$ to $1.29, \mathrm{P}=0.55,12$ studies). This is consistent with our review which includes RCTs only.

There is another systematic review evaluating defibrotide for prophylaxis of hepatic VOD in HSCT recipients (Zhang 2012). This review included one RCT, four cohort studies and eight case series with a total of 1230 participants. It included the same RCT (Corbacioglu 2012) as in our review. The review found that the overall mean incidence of VOD in participants who received defibrotide was lower compared with those who did not receive defibrotide (4.7\% versus $13.7 \%$, RR $0.47,95 \% \mathrm{Cl} 0.31$ to $0.73, \mathrm{P}=$ $0.0006,5$ studies). However, the authors made similar comments to ours that the methodological weaknesses of the studies precluded making generalisable conclusions and that large RCTs were needed for further confirmation.

\section{AUTHORS' CONCLUSIONS}

\section{Implications for practice}

There is evidence of low quality that ursodeoxycholic acid might be effective in reducing the incidence of hepatic veno-occlusive disease (VOD), overall mortality and mortality due to hepatic VOD in haematopoietic stem call transplant (HSCT) recipients. However, it is uncertain whether ursodeoxycholic acid benefits all HSCT recipients or only a subset of high-risk people. The optimal regimen of ursodeoxycholic acid for prophylaxis of hepatic VOD has not been well defined. Ursodeoxycholic acid is not associated with excess adverse events compared with control groups in randomised controlled trials (RCTs). However, the small number of participants included in the RCTs precludes firm conclusion on rare adverse events. There is insufficient evidence to support the use of other prophylactic regimens, including heparin, low molecular weight heparin, defibrotide, glutamine, fresh frozen plasma, antithrombin III, or prostaglandin E1.

\section{Implications for research}

The existing trials are of small size and low methodological quality. Further high-quality RCTs of larger sample size are needed to assess the effectiveness of ursodeoxycholic acid for prophylaxis of hepatic VOD in HSCT recipients to validate its effectiveness, and to determine the group of people most likely to benefit and the optimal dosage regimen. Other therapeutic options such as defibrotide, heparin, low molecular weight heparin, glutamine, fresh frozen plasma and antithrombin III, alone or in combination with ursodeoxycholic acid also need more highquality RCTs of larger sample size for further evaluation. Adequate random sequence generation, allocation concealment, blinding of participants, clinicians and outcome assessors are essential.

\section{ACKNOWLEDGEMENTS}

We thank the librarians of The University of Hong Kong for retrieving relevant references. We are also grateful to the Cochrane Haematological Malignancies Group (Kathrin Bauer, Sabine Kluge, Andrea Will and Ina Monsef) for their editorial support and help in searching various literature. 


\section{R E F E R E N C E S}

\section{References to studies included in this review}

\section{Attal 1992 \{published data only\}}

Attal M, Huguet F, Rubie H, Huynh A, Charlet JP, Payen JL, et al. Prevention of hepatic veno-occlusive disease after bone marrow transplantation by continuous infusion of low-dose heparin: a prospective, randomised trial. Blood 1992;79(11):2834-40.

\section{Brown 1998 \{published data only\}}

Brown SA, Goringe A, Fegan C, Davies SV, Giddings J, Whittaker JA, et al. Parenteral glutamine protects hepatic function during bone marrow transplantation. Bone Marrow Transplantation 1998;22(3):281-4.

\section{Corbacioglu 2012 \{published data only\}}

Corbacioglu S, Cesaro S, Faraci M, Schulz A, Greil J, Schrum J, et al. Defibrotide (DF) for the prevention of hepatic veno-occlusive disease (VOD) in paediatric stem cell trans-plantation: Results of a prospective randomised Phase II/III, multicenter trial. European Journal of Pediatrics 2010;169(3):380.

Corbacioglu S, Cesaro S, Faraci M, Valteau-Couanet D, Gruhn B, Boelens JJ, et al. Defibrotide (DF) for the prevention of hepatic veno-occlusive disease (VOD) in paediatric stem cell transplantation: Results of a prospective phase II/III randomised, multicenter study. Blood 2009;114(22):653.

Corbacioglu S, Cesaro S, Faraci M, Valteau-Couanet D, Gruhn B, Boelens JJ, et al. Defibrotide prevents hepatic VOD and reduces significantly VOD-associated complications in children at high risk: Final results of a prospective phase II/III multicenter study. Bone Marrow Transplantation 2010;45:S1.

* Corbacioglu S, Cesaro S, Faraci M, Valteau-Couanet D, Gruhn B, Rovelli A, et al. Defibrotide for prophylaxis of hepatic veno-occlusive disease in paediatric haemopoietic stem-cell transplantation: an open-label, phase 3 , randomised controlled trial. Lancet 2012;379(9823):1301-9.

\section{Demuynck 1995 \{published data only\}}

Demuynck H, Vandenberghe P, Verhoef GEG, Zachee P, Boogaerts MA. Prevention of veno-occlusive disease (VOD) of the liver after marrow and blood progenitor cell transplantation: a prospective randomised study of different prophylactic regimens. Blood 1995;86(10 Suppl 1):620a.

\section{Essell 1998 \{published data only\}}

Essell J, Schroeder M, Thompson J, Harman G, Halvorson R, Callander N. A randomised double-blind trial of prophylactic ursodeoxycholic acid (UDCA) vs placebo to prevent venoocclusive disease of the liver (VOD) in patients undergoing allogeneic bone marrow transplantation (BMT). Blood 1994;84:250a.

* Essell JH, Schroeder MT, Harman GS, Halvorson R, Lew V, Callander N, et al. Ursodiol prophylaxis against hepatic complications of allogeneic bone marrow transplantation. A randomised, double-blind, placebo-controlled trial. Annals of Internal Medicine 1998;128:975-81.
Jung 2005 \{published data only\}

Jung CW, Lee J, Park BB, Park SH, Kim JH, Kwon JM, et al. A randomized trial of heparin plus anti-thrombin III (ATIII) vs. heparin alone to prevent VOD after HSCT. Blood 2005;106(11 Part 1):503.

\section{Lee 1996 \{published data only\}}

Lee LH, Chiang T, Linn YC, Wong GC, Teoh G, Tan P. Low molecular weight heparin in prophylaxis of veno-occlusive disease in patients undergoing bone marrow transplantation. Blood 1996;88(10):414a.

\section{Marsa-Vila 1991 \{published data only\}}

Marsa-Vila L, Gorin NC, Laporte JP, Labopin M, DupuyMontbrun MC, Fouillard L, et al. Prophylactic heparin does not prevent liver veno-occlusive disease following autologous bone marrow transplantation. European Journal of Haematology 1991;47(5):346-54.

\section{Matsumoto 2007 \{published data only\}}

* Matsumoto M, Kawa K, Uemura M, Kato S, Ishizashi H, Isonishi A, et al. Prophylactic fresh frozen plasma may prevent development of hepatic VOD after stem cell transplantation via ADAMTS13-mediated restoration of von Willebrand factor plasma levels. Bone Marrow Transplantation 2007;40(3):251-9.

Matsumoto M, Kawa K, Yagi H, Park Y, Takeshima Y, Kosaka Y. Infusions of fresh frozen plasma to the patients with a high-risk group for hepatic VOD associated with stem cell transplantation reduce its occurrence. Blood 2006;108(11):433a.

\section{Ohashi 2000 \{published data only\}}

Ohashi K, Tanabe J, Watanabe R, Sakamaki H, Maruta A, Okamoto $S$, et al. The Japanese multicenter open randomised trial of prophylactic ursodeoxycholic acid for veno-occlusive disease on the liver in patients undergoing stem cell transplantation. Blood 1998;92(10 Suppl 1 Pt 1 of 2):276a.

* Ohashi K, Tanabe J, Watanabe R, Tanaka T, Sakamaki H, Maruta A, et al. The Japanese multicenter open randomised trial of ursodeoxycholic acid prophylaxis for hepatic venoocclusive disease after stem cell transplantation. American Journal of Hematology 2000;64(1):32-8.

\section{Or 1996 \{published data only\}}

Or R, Drakos P, Nagler A, Naparstek E, Kapelushnik J, Elad S. Prophylaxis of hepatic veno-occlusive disease (VOD) following bone-marrow transplantation (BMT) with low molecular weight heparin (LMHW). British Journal of Haematology 1994;87(Suppl 1):42.

* Or R, Nagler A, Shpilberg O, Elad S, Naparstek E, Kapelushnik J, et al. Low molecular weight heparin for the prevention of veno-occlusive disease of the liver in bone marrow transplantation patients. Transplantation 1996;61(7):1067-71.

Park 2002 \{published data only\}

* Park SH, Lee MH, Lee H, Kim HS, Kim K, Kim WS, et al. A randomised trial of heparin plus ursodiol vs. heparin alone to

Interventions for prophylaxis of hepatic veno-occlusive disease in people undergoing haematopoietic stem cell transplantation (Review) $\mathbf{3 5}$ Copyright (c) 2015 The Cochrane Collaboration. Published by John Wiley \& Sons, Ltd. 
prevent hepatic veno-occlusive disease after hematopoietic stem cell transplantation. Bone Marrow Transplantation 2002;29(2):137-43.

Park SH, Lee MH, Lee H, Kim HS, Kim SW, Kim K, et al. A randomised trial of heparin plus ursodiol versus heparin alone to prevent hepatic veno-occlusive disease after hematopoietic stem cell transplantation. Blood 2001;98(11 Pt 2 of 2 Parts):854a.

\section{Ruutu 2002 \{published data only\}}

Ruutu T, Eriksson B, Remes K, Juvonen E, Volin L, Remberger M, et al. Ursodeoxycholic acid for the prevention of hepatic complications in allogeneic stem cell transplantation. Blood 2002;100(6):1977-83.

\section{Yannaki 2012 \{published data only\}}

Yannaki E, Constantinou V, Baliakas P, Kaloyannidis P, Batsis I, Papadopoulou A, et al. Intravenous versus oral busulfan administration results into a dramatic reduction of venoocclusive disease (VOD) incidence in a randomised trial assessing fresh frozen plasma+heparin versus heparinalone as anti-VOD prophylaxis. Bone Marrow Transplantation 2012;47:S198.

\section{References to studies excluded from this review}

\section{Carbacioglu 2004 \{published data only\}}

Corbacioglu S, Greil J, Peters C, Wulffrant N, Laws HJ, Dilloo D, et al. Defibrotide in the treatment of children with venoocclusive disease (VOD): a retrospective multicenter study demonstrates therapeutic efficacy upon early intervention. Bone Marrow Transplantation 2004;33(2):189-95.

\section{References to ongoing studies}

JPRN-UMIN000013455 \{published data only\}

JPRN-UMIN000013455. Efficacy and safety study of defibrotide (DF) for the prophylaxis of veno-occlusive disease (VOD). apps.who.int/trialsearch/Trial2.aspx? TrialID=JPRN-UMIN000013455 (accessed 1st May 2015). [JPRNUMIN000013455]

\section{NCT00563498 \{published data only\}}

NCT00563498. A randomized control study on the effects of glutamine on the clinical outcome of bone marrow transplant recipients with special reference to veno-occlusive disease and mucositis. www.clinicaltrials.gov/show/NCT00563498 (accessed 1st May 2015). [NCT00563498]

\section{Additional references}

\section{Antin 1992}

Antin JH, Ferrara JLM. Cytokine dysregulation and acute graftversus-host disease. Blood 1992;80:2964-8.

\section{Barker 2003}

Barker CC, Butzner JD, Anderson RA, Brant R, Sauve RS. Incidence, survival and risk factors for the development of veno-occlusive disease in pediatric hematopoietic stem cell transplant recipients. Bone Marrow Transplantation 2003;32(1):79-87.

\section{Batsis 2006}

Batsis I, Yannaki E, Kaloyannidis P, Sakellari I, Smias C, Georgoulis I, et al. Veno-occlusive disease prophylaxis with fresh frozen plasma and heparin in bone marrow transplantation. Thrombosis Research 2006;118(5):611-8.

\section{Bearman 1995}

Bearman SI. The syndrome of hepatic veno-occlusive disease after marrow transplantation. Blood 1995;85(11):3005-20.

\section{Bianchi 1993}

Bianchi G, Barone D, Lanzarotti E, Tettamanti R, Porta R, Moltrasio D, et al. Defibrotide, a single-stranded polydeoxyribonucleotide acting as an adenosine receptor agonist. Journal of Pharmacology 1993;238(2-3):327-34.

\section{Bracht 1994}

Bracht F, Schrör K. Isolation and identification of aptamers from defibrotide that act as thrombin antagonists in vitro. Biochemical and Biophysical Research Communications 1994;200(2):933-6.

\section{Capelli 2009}

Capelli B, Chiesa R, Evangelio C, Biffi A, Roccia T, Frognoli I, et al. Absence of VOD in paediatric thalassaemic HSCT recipients using defibrotide prophylaxis and intravenous busulfan. British Journal of Haematology 2009;147(4):554-60.

\section{Cella 2001}

Cella G, Sbarai A, Mazzaro G, Motta G, Carraro P, Andreozzi GM, et al. Tissue factor pathway inhibitor release induced by defibrotide and heparins. Clinical and Applied Thrombosis/ Hemostasis 2001;7(3):225-8.

\section{Cesaro 2005}

Cesaro S, Pillon M, Talenti E, Toffolutti T, Calore E, Tridello G, et al. A prospective survey on incidence, risk factors and therapy of hepatic veno-occlusive disease in children after hematopoietic stem cell transplantation. Haematologica 2005;90(10):1396-404.

\section{Chalandon 2004}

Chalandon Y, Roosnek E, Mermillod B, Newton A, Ozsahin H, Wacker $\mathrm{P}$, et al. Prevention of veno-occlusive disease with defibrotide after allogeneic stem cell transplantation. Biology of Blood and Marrow Transplantation 2004;10(5):347-54.

\section{Cheuk 2007}

Cheuk DKL, Wang P, Lee TL, Chiang AKS, Ha SY, Lau YL, et al. Risk factors and mortality predictors of hepatic veno-occlusive disease after pediatric hematopoietic stem cell transplantation. Bone Marrow Transplantation 2007;40(10):935-44.

\section{Coccheri 1988}

Coccheri S, Biagi G, Legnani C, Bianchini B, Grauso F. Acute effects of defibrotide, an experimental antithrombotic agent, on fibrinolysis and blood prostanoids in man. European Journal of Clinical Pharmacology 1988;35(2):151-6. 


\section{Coppell 2010}

Coppell JA, Richardson PG, Soiffer R, Martin PL, Kernan NA, Chen $A$, et al. Hepatic veno-occlusive disease following stem cell transplantation: incidence, clinical course, and outcome. Biology of Blood and Marrow Transplantation 2010;16(2):157-68.

\section{Corbacioglu 2006}

Corbacioglu S, Hönig M, Lahr G, Stöhr S, Berry G, Friedrich W, et al. Stem cell transplantation in children with infantile osteopetrosis is associated with a high incidence of VOD, which could be prevented with defibrotide. Bone Marrow Transplantation 2006;38(8):547-53.

\section{Deeks 2011}

Deeks JJ, Higgins JPT, Altman DG (editors). Chapter 9: Analysing data and undertaking meta-analyses. In: Higgins JPT, Green $\mathrm{S}$ (editors). Cochrane Handbook for Systematic Reviews of Interventions Version 5.1.0 (updated March 2011). The Cochrane Collaboration, 2011. Available from www.cochranehandbook.org. [Available from www.cochrane-handbook.org]

\section{DeLeve 2002}

DeLeve LD, Shulman HM, McDonald GB. Toxic injury to hepatic sinusoids: sinusoidal obstruction syndrome. Seminars in Liver Diseases 2002;22(1):623-38.

\section{Dignan 2007}

Dignan F, Gujral D, Ethell M, Evans S, Treleaven J, Morgan G, et al. Prophylactic defibrotide in allogeneic stem cell transplantation: minimal morbidity and zero mortality from veno-occlusive disease. Bone Marrow Transplantation 2007;40(1):79-82.

\section{Echart 2009}

Echart CL, Graziadio B, Somaini S, Ferro LI, Richardson PG, Fareed J. The fibrinolytic mechanism of defibrotide: effect of defibrotide on plasmin activity. Blood Coagulation Fibrinolysis 2009;20(8):627-34.

\section{Essell 1992}

Essell JH, Thompson JM, Harman GS, Halvorson RD, Snyder MJ, Callender NS, et al. Pilot trial of prophylactic ursodiol to decrease the incidence of veno-occlusive disease of the liver in allogeneic bone marrow transplant patients. Bone Marrow Transplantation 1992;10(4):367-72.

\section{Falanga 2003}

Falanga A, Vignoli A, Marchetti M, Barbui T. Defibrotide reduced procoagulant activity and increases fibrinolytic properties of endothelial cells. Leukemia 2003;17(8):1636-42.

\section{Feldman 1996}

Feldman L, Milovic V, Jaimovich G, Requejo A, Altclas J, Brioschi S. Prevention of hepatic veno-occlusive disease after bone marrow transplantation (BMT) by continuous infusion of low-dose heparin. Blood 1996;88(Suppl 1):254B.

\section{Forrest 2003}

Forrest DL, Thompson K, Dorcas VG, Couban SH, Pierce R. Low molecular weight heparin for the prevention of hepatic veno-occlusive disease (VOD) after hematopoietic stem cell transplantation: a prospective phase II study. Bone Marrow Transplantation 2003;31(12):1143-9.

\section{Gluckman 1990}

Gluckman E, Jolivet I, Scrobohaci ML, Devergie A, Traineau R, Bourdeau-Esperou $\mathrm{H}$, et al. Use of prostaglandin $\mathrm{E} 1$ for prevention of liver veno-occlusive disease in leukaemic patients treated by allogeneic bone marrow transplantation. British Journal of Haematology 1990;74(3):277-81.

\section{GRADEpro 2008 [Computer program]}

Brozek JL, Oxman A, Shünneman H. GRADEpro. Version 3.2 for Windows. GRADE Working Group, 2008.

\section{Hallahan 1989}

Hallahan DE, Spriggs DR, Beckett MA, Kufe DW, Weichselbaum RR. Increased tumour necrosis factor alpha mRNA after cellular exposure to ionising radiation. Proceedings of the National Academy of Sciences 1989;86(24):10104-7.

\section{Hasegawa 1998}

Hasegawa S, Horibe K, Kawabe T, Kato K, Kojima S, Matsuyama T, et al. Veno-occlusive disease of the liver after allogeneic bone marrow transplantation in children with hematologic malignancies: incidence, onset time and risk factors. Bone Marrow Transplantation 1998;22(12):1191-7.

\section{Helmy 2006}

Helmy A. Review article: updates in the pathogenesis and therapy of hepatic sinusoidal obstruction syndrome. Alimentary Pharmacology \& Therapeutics 2006;23(1):11-25.

\section{Higgins 2011a}

Higgins JPT, Deeks JJ (editors). Chapter 7: Selecting studies and collecting data. In: Higgins JPT, Green S (editors). Cochrane Handbook for Systematic Reviews of Interventions Version 5.1.0 (updated March 2011). The Cochrane Collaboration, 2011. Available from www.cochrane-handbook.org.

\section{Higgins 2011b}

Higgins JPT, Altman DG, Sterne JAC (editors). Chapter 8: Assessing risk of bias in included studies. In: Higgins JPT, Green S (editors). Cochrane Handbook for Systematic Reviews of Interventions Version 5.1.0 (updated March 2011). The Cochrane Collaboration, 2011. Available from www.cochranehandbook.org.

\section{Higgins 2011c}

Higgins JPT, Deeks JJ, Altman DG (editors). Chapter 16: Special topics in statistics. In: Higgins JPT, Green S (editors). Cochrane Handbook for Systematic Reviews of Interventions Version 5.1.0 (updated March 2011). The Cochrane Collaboration, 2011. Available from www.cochrane-handbook.org.

\section{Horn 2002}

Horn B, Reiss U, Matthay K, McMillan A, Cowan M. Veno-occlusive disease of the liver in children with solid tumours undergoing autologous hematopoietic progenitor cell transplantation: a high incidence in patients with neuroblastoma. Bone Marrow Transplantation 2002;29(5):409-15. 


\section{Iba 2008}

Iba T, Miyasho T. Danaparoid sodium attenuates the increase in inflammatory cytokines and preserves organ function in endotoxaemic rats. Critical Care 2008;12(4):R86.

\section{Imran 2006}

Imran H, Tleyjeh IM, Zirakzadeh A, Rodriguez V, Khan SP. Use of prophylactic anticoagulation and the risk of hepatic venoocclusive disease in patients undergoing hematopoietic stem cell transplantation: a systematic review and meta-analysis. Bone Marrow Transplantation 2006;37(7):677-86.

\section{Jones 1987}

Jones RJ, Lee KSK, Beschomer WE, Vogel VG, Growchow LB, Braine HG, et al. Venoocclusive disease of the liver following bone marrow transplantation. Transplantation 1987;44(6):778-83.

\section{Krivoy 2008}

Krivoy N, Hoffer E, Lurie Y, Bentur Y, Rowe JM. Busulfan use in hematopoietic stem cell transplantation: pharmacology, dose adjustment, safety and efficacy in adults and children. Current Drug Safety 2008;3(1):60-6.

\section{Lee 2010}

Lee SH, Yoo KH, Sung KW, Koo HH, Kwon YJ, Kwon MM, et al. Hepatic veno-occlusive disease in children after hematopoietic stem cell transplantation: incidence, risk factors, and outcome. Bone Marrow Transplantation 2010;45(8):1287-93.

\section{Lefebvre 2011}

Lefebvre C, Manheimer E, Glanville J (editors). Chapter 6: Searching for studies. In Higgins JPT, Green S (editors). Cochrane Handbook for Systematic Reviews of Interventions Version 5.1.0 [updated March 2011]. The Cochrane Collaboration, 2011. Available from www.cochranehandbook.org.

\section{McDonald 1984}

McDonald GB, Sharma P, Matthews DE, Shulman HM, Thomas ED. Veno-occlusive disease of the liver after bone marrow transplantation: diagnosis, incidence and predisposing factors. Hepatology 1984;4(1):116-22.

\section{McDonald 1993}

McDonald GB, Hinds MS, Fisher LD, Schoch HG, Wolford JL, Benaji $\mathrm{M}$, et al. Veno-occlusive disease of the liver and multiorgan failure after bone marrow transplantation: a cohort study of 355 patients. Annals of Internal Medicine 1993;18(4):255-67.

\section{Ozkaynak 1991}

Ozkaynak MF, Weinberg K, Kohn D, Sender L, Parkman R, Lenarsky C. Hepatic veno-occlusive disease post-bone marrow transplantation in children conditioned with busulfan and cyclophosphamide: incidence, risk factors, and clinical outcome. Bone Marrow Transplantation 1991;7(6):467-74.

\section{Pasini 1996}

Pasini FL, Frigerio C, Capecchi PL, Ceccatelli L, Messa GL, Franchi M, et al. Modulation of venous endothelial activity and transcellular calcium transport by defibrotide: the adenosine hypothesis. Seminars in Thrombosis and Hemostasis 1996;22(Suppl 1):15-20.

\section{Qureshi 2008}

Qureshi A, Marshall L, Lancaster D. Defibrotide in the prevention and treatment of veno-occlusive disease in autologous and allogeneic stem cell transplantation in children. Pediatric Blood Cancer 2008;50(4):831-2.

\section{Reiss 2002}

Reiss U, Cowan M, McMillan A, Horn B. Hepatic veno-occlusive disease in blood and bone marrow transplantation in children and young adults: incidence, risk factors, and outcome in a cohort of 241 patients. Journal of Pediatric Hematology/ Oncology 2002;24(9):746-50.

\section{RevMan 2014 [Computer program]}

The Nordic Cochrane Centre, The Cochrane Collaboration. Review Manager (RevMan). Version 5.3. Copenhagen: The Nordic Cochrane Centre, The Cochrane Collaboration, 2014.

\section{Sakaguchi 2010}

Sakaguchi H, Watanabe N, Muramatsu H, Doisaki S, Yoshida N, Matsumoto K, et al. Danaparoid as the prophylaxis for hepatic veno-occlusive disease after allogeneic hematopoietic stem cell transplantation in childhood hematological malignancy. Pediatric Blood Cancer 2010;55(6):1118-25.

\section{Schünemann 2011}

Schünemann HJ, Oxman AD, Vist GE, Higgins JPT, Deeks JJ, Glasziou P, et al (editors). Chapter 12: Interpreting results and drawing conclusions. In: Higgins JPT, Green $S$ (editors). Cochrane Handbook for Systematic Reviews of Interventions Version 5.1.0 (updated March 2011). The Cochrane Collaboration, 2011. Available from www-cochranehandbook.org.

\section{Simon 2001}

Simon M, Hahn T, Ford LA, Anderson B, Swinnich D, Baer MR, et al. Retrospective multivariate analysis of hepatic venoocclusive disease after blood or marrow transplantation: possible beneficial use of low molecular weight heparin. Bone Marrow Transplantation 2001;27(6):627-33.

\section{Song 2006}

Song JS, Seo JJ, Moon HN, Ghim T, Im HJ. Prophylactic lowdose heparin or prostaglandin E1 may prevent severe venoocclusive disease of the liver after allogeneic hematopoietic stem cell transplantation in Korean children. Journal of Korean Medical Science 2006;21(5):897-903.

\section{Sterne 2011}

Sterne JAC, Egger M, Moher D (editors). Chapter 10: Addressing reporting biases. In Higgins JPT, Green S (editors). Cochrane Handbook for Systematic Reviews of Intervention. Version 5.1.0 (updated March 2011). The Cochrane Collaboration, 2011. Available from www.cochrane-handbook.org. 


\section{Styler 1996}

Styler M, Crilley P, Topolsky D, Rubin S, Sabol P, King R, et al. Low molecular weight heparin prophylaxis for veno-occlusive disease in unrelated marrow transplant recipients. Blood 1996;88(Suppl 1):259B.

\section{Tay 2007}

Tay J, Tinmouth A, Fergusson D, Huebsch L, Allan DS. Systematic review of controlled clinical trials on the use of ursodeoxycholic acid for the prevention of hepatic venoocclusive disease in hematopoietic stem cell transplantation. Biology of Blood and Marrow Transplantation 2007;13(2):206-17.

\section{Teicher 1988}

Teicher BA, Crawford JM, Holden SA, Lin Y, Cathcart KN, Luchette CA, et al. Glutathione monoethyl ester can selectively protect liver from high dose BCNU or cyclophosphamide. Cancer 1988;62(7):1275-81.

\section{Thornley 2004}

Thornley I, Lehmann LE, Sung L, Holmes C, Spear JM, Brennan $\mathrm{L}$, et al. A multi-agent strategy to decrease regimen-related toxicity in children undergoing allogeneic hematopoietic stem cell transplantation. Bone Marrow Transplantation 2004;10(9):635-44.

\section{Tierney 2007}

Tierney JF, Stewart LA, Ghersi D, Burdett S, Sydes MR. Practical methods for incorporating summary time-to-event data into meta-analysis. Trials 2007;8:16.

\section{Toh 1999}

Toh HC, McAfee SL, Sackstein R, Cox BF, Colby C, Spitzer R. Late onset veno-occlusive disease following high-dose chemotherapy and stem cell transplantation. Bone Marrow Transplantation 1999;24(8):891-5.

\section{Yoshikawa 1992}

Yoshikawa M, Tsujii T, Matsumura K, Yamao J, Matsumura Y, Kubo R, et al. Immunomodulatory effects of ursodeoxycholic acid on immune responses. Hepatology 1992;16(2):358-64.

\section{Zhang 2012}

Zhang L, Wang Y, Huang H. Defibrotide for the prevention of hepatic veno-occlusive disease after hematopoietic stem cell transplantation: a systematic review. Clinical Transplantation 2012;26(4):511-9.

\section{Zhou 1994}

Zhou Q, Zhu X, Ruan C. Defibrotide stimulates expression of thrombomodulin in human endothelial cells. Thrombosis and Haemostasis 1994;71(4):507-10.

\section{References to other published versions of this review Cheuk 2011}

Cheuk DKL, Chiang, AKS, Ha, SY, Chan GCF. Interventions for prophylaxis of hepatic veno-occlusive disease in patients undergoing hematopoietic stem cell transplantation. Cochrane Database of Systematic Reviews 2011, Issue 9. [DOI: 10.1002/14651858.CD009311]

* Indicates the major publication for the study

\section{CHARACTERISTICS OF STUDIES}

Characteristics of included studies [ordered by study ID]

Attal 1992

\begin{tabular}{|c|c|}
\hline Methods & $\begin{array}{l}\text { - Study design: parallel-group randomised controlled trial } \\
\text { - Stratification factor: type of graft (allogeneic or autologous) } \\
\text { - Settings: inpatients } \\
\text { - Study dates: January } 1998 \text { to September } 1991 \\
\text { - Location: France }\end{array}$ \\
\hline Participants & $\begin{array}{l}\text { - Inclusion criteria: unpurged autologous or non-T-depleted HLA genoidentical allogeneic bone mar- } \\
\text { row transplant using standard conditioning regimen } \\
\text { - Exclusion criteria: had lesions at risk of bleeding (e.g., recent history of peptic ulcer disease), history } \\
\text { of deep vein thrombosis, non-standard conditioning regimen, mismatched allogeneic stem cell trans- } \\
\text { plant, matched unrelated allogeneic transplant } \\
\text { - Number of participants (intervention group : control group): } 81: 80 \\
\text { - Number of men (intervention group : control group): } 55: 47 \\
\text { - Age of participants (intervention group : control group): mean (SD) in years: } 36.3(14.4): 35.9(14) \\
\text { - Underlying diseases: Intervention group: AML (17), ALL (15), CML (18), myeloma (16), lymphoma (13), } \\
\text { aplasia (2); Control group: AML (15), ALL (16), CML (12), myeloma (17), lymphoma (16), aplasia (4) } \\
\text { - Previous treatments (intervention group : control group): information not available } \\
\text { - Pre-existing liver dysfunction (intervention group : control group): AST > } 40 \text { IU/L: } 10: 7 \text {; Bilirubin > } 19 \\
\text { micromol/L: } 2: 5\end{array}$ \\
\hline
\end{tabular}


Attal 1992 (Continued)

- Previous history of hepatic VOD (intervention group : control group): $0: 0$

- Performance status before transplant (intervention group : control group): information not available

- Type of transplant: Intervention group: allogeneic (39), syngeneic (1), autologous (41); Control group: allogeneic (38), syngeneic (1), autologous (41)

- Donor (intervention group : control group): allogeneic (39), syngeneic (1), autologous (41); Control group: allogeneic (38), syngeneic (1), autologous (41)

- HLA disparity (intervention group : control group): information not available

- Stem cell source (intervention group : control group): all participants received bone marrow

- Stem cell manipulation (intervention group : control group): no manipulation for all participants

- Conditioning regimen: Intervention group: CY-TBI (31), MEL-TBI (14), BU-CY (25), CBV (11); Control group: CY-TBI (31), MEL-TBI (16), BU-CY (19), CBV (14)

- GVHD prophylaxis (intervention group : control group): methotrexate and cyclosporin for all participants who received allogeneic transplant

\begin{tabular}{ll}
\hline Interventions & $\begin{array}{l}\text { Intervention group }(\mathrm{N}=81) \text { : heparin } 100 \text { units/kg/day by continuous intravenous infusion from start } \\
\text { of conditioning till } 30 \text { days post-transplant or discharge from sterile unit, whichever occurred first } \\
\text { - Control group }(\mathrm{N}=80) \text { : no heparin infusion }\end{array}$ \\
\hline Outcomes & Incidence of hepatic VOD \\
- Overall survival \\
- Mortality attributable to hepatic VOD \\
- Frequency of adverse event (bleeding) \\
- Duration of follow-up: 100 days post-transplant \\
- Loss to follow-up (intervention group : control group): $0: 0$ \\
- The mean interval between diagnosis and BMT appeared to be shorter in the intervention group (12.8 \\
months) compared to the control group (16.1 months) \\
- Funding source: information not available \\
\hline
\end{tabular}

\section{Risk of bias}

\begin{tabular}{lll}
\hline Bias & Authors' judgement & Support for judgement \\
\hline $\begin{array}{l}\text { Random sequence genera- } \\
\text { tion (selection bias) }\end{array}$ & Low risk & $\begin{array}{l}\text { Computer-generated randomisation sequence prepared by biostatistics de- } \\
\text { partment }\end{array}$ \\
\hline
\end{tabular}

\begin{tabular}{lll}
\hline $\begin{array}{l}\text { Allocation concealment } \\
\text { (selection bias) }\end{array}$ & Low risk & $\begin{array}{l}\text { Randomisation sequence unknown to the physicians participating in the trial, } \\
\text { treatment allocation assigned via telephone }\end{array}$ \\
\hline $\begin{array}{l}\text { Blinding of participants } \\
\text { and personnel (perfor- } \\
\text { mance bias) }\end{array}$ & High risk & Neither participants nor personnel were blinded \\
All outcomes & \\
\hline
\end{tabular}

\begin{tabular}{lll}
$\begin{array}{l}\text { Blinding of outcome as- } \\
\text { sessment (detection bias) } \\
\text { All outcomes }\end{array}$ & High risk & Physicians who assessed for presence of clinical hepatic VOD were not blinded \\
\hline $\begin{array}{l}\text { Incomplete outcome data } \\
\text { (attrition bias) } \\
\text { All outcomes }\end{array}$ & Low risk & Follow-up was complete for all participants \\
\hline $\begin{array}{l}\text { Selective reporting (re- } \\
\text { porting bias) }\end{array}$ & Unclear risk & $\begin{array}{l}\text { Protocol was not available. It was unclear whether all pre-specified outcomes } \\
\text { were reported }\end{array}$ \\
\hline
\end{tabular}


Attal 1992 (Continued)

Other bias High risk

Diagnostic criteria or diagnostic evaluation for hepatic VOD was not uniform. The interval between diagnosis and BMT appeared to be shorter in the intervention group compared to the control group. Hence the 2 groups might not be comparable at baseline

Brown 1998

Methods $\quad$ - Study design: parallel-group randomised controlled trial
- Stratification factor: none
- Sttings: inpatients
- Location: UK

Participants

- Inclusion criteria: people undergoing stem cell transplant

- Exclusion criteria: information not available

- Number of participants (intervention group : control group): $18: 16$

- Number of men (intervention group : control group): $11: 9$

- Age of participants (intervention group : control group): median (range) in years: 41 (19 - 62) : 32 (16 - 55)

- Underlying diseases: Intervention group: AML (2), ALL (1), CML (2), myeloma (2), non-Hodgkin lymphoma (6), Hodgkin lymphoma (5); Control group: AML (3), ALL (0), CML (2), myeloma (1), non-Hodgkin lymphoma (7), Hodgkin lymphoma (3)

- Previous treatments (intervention group : control group): information not available.

- Pre-existing liver dysfunction (intervention group : control group): information not available

- Previous history of hepatic VOD (intervention group : control group): information not available

- Performance status before transplant (intervention group : control group): information not available

- Type of transplant: Intervention group: allogeneic (3), autologous (15); Control group: allogeneic (4), autologous (12)

- Donor (intervention group : control group): allogeneic (3), autologous (15); Control group: allogeneic (4), autologous (12)

- HLA disparity (intervention group : control group): information not available

- Stem cell source: Intervention group: bone marrow (7), peripheral blood stem cell (11); Control group: bone marrow (8), peripheral blood stem cell (8)

- Stem cell manipulation (intervention group : control group): information not available

- Conditioning regimen: Intervention group: BEAM (10), CY-TBI (4), BU-CY (4); Control group: BEAM (9), CY-TBI (5), BU-CY (2)

- GVHD prophylaxis (intervention group : control group): information not available

Interventions

- Intervention group $(\mathrm{N}=18)$ : glycl-L-glutamine $50 \mathrm{~g}$ intravenous infusion daily from the start of conditioning till discharge from the transplant unit

- Control group ( $\mathrm{N}=16$ ): placebo (isonitrogenous mixture of non-essential amino acids) $50 \mathrm{~g}$ intravenous infusion daily from the start of conditioning till discharge from the BMT unit

\begin{tabular}{ll}
\hline Outcomes & Incidence of hepatic VOD \\
- All-cause mortality \\
- Mortality attributable to hepatic VOD \\
- Frequency of adverse events \\
\hline - Duration of follow-up: till discharge from BMT unit \\
- Loss to follow-up (intervention group : control group): $0: 0$ \\
- Warfarin was used in 9 participants in the intervention group but only 2 participants in the control \\
group. 1 participant in the treatment group withdrew from the trial because of symptom of abdominal
\end{tabular}


Brown 1998 (Continued)

fullness. 3 other participants in the treatment group withdrew without reason given. 1 participant in the control group withdrew treatment because of problems with the supply of amino acid solution. Another participant in the control group did not complete treatment because he died soon from sepsis and graft-versus-host disease

- Funding source: information not available

- Declarations of interest: information not available

\section{Risk of bias}

\begin{tabular}{|c|c|c|}
\hline Bias & Authors' judgement & Support for judgement \\
\hline $\begin{array}{l}\text { Random sequence genera- } \\
\text { tion (selection bias) }\end{array}$ & Unclear risk & Random sequence generation was not described \\
\hline $\begin{array}{l}\text { Allocation concealment } \\
\text { (selection bias) }\end{array}$ & Unclear risk & Allocation concealment was not described \\
\hline $\begin{array}{l}\text { Blinding of participants } \\
\text { and personnel (perfor- } \\
\text { mance bias) } \\
\text { All outcomes }\end{array}$ & Low risk & Both participants and study personnel were blinded \\
\hline $\begin{array}{l}\text { Blinding of outcome as- } \\
\text { sessment (detection bias) } \\
\text { All outcomes }\end{array}$ & Unclear risk & Blinding of outcome assessors was not described \\
\hline $\begin{array}{l}\text { Incomplete outcome data } \\
\text { (attrition bias) } \\
\text { All outcomes }\end{array}$ & Low risk & $\begin{array}{l}\text { Withdrawal of treatment occurred in some participants but their outcomes } \\
\text { were reported }\end{array}$ \\
\hline $\begin{array}{l}\text { Selective reporting (re- } \\
\text { porting bias) }\end{array}$ & Unclear risk & $\begin{array}{l}\text { Protocol was not available. It was unclear whether all pre-specified outcomes } \\
\text { were reported }\end{array}$ \\
\hline Other bias & High risk & $\begin{array}{l}\text { Warfarin was used more often in the intervention group compared to the con- } \\
\text { trol group. The participants in the intervention group also appeared to be old- } \\
\text { er than those in the control group. Hence the } 2 \text { groups might not be compara- } \\
\text { ble at baseline. Withdrawal of treatment occurred in } 22 \% \text { of participants in the } \\
\text { intervention group and } 25 \% \text { of participants in the control group which might } \\
\text { cause bias }\end{array}$ \\
\hline
\end{tabular}

Corbacioglu 2012

\begin{tabular}{ll}
\hline Methods & - Study design: parallel-group randomised controlled trial \\
- Stratification factor: stratified by centre and diagnosis of osteopetrosis \\
- Settings: inpatients \\
- Study dates: 25 January 2006 to 29 January 2009 \\
- Location: 28 centres in Europe \\
\hline Participants \\
- Inclusion criteria: age below 18 years, undergoing myeloablative conditioning for allogeneic or autol- \\
- Exclusion criteria: pregnant women, or people who were transplanted but did not fulfil inclusion cri- \\
teria \\
- Number of participants (intervention group : control group): $181: 179$ \\
gumber of men (intervention group : control group): $110: 101$ (gender in 1 participant in intervention \\
group and 3 participants in control group unknown)
\end{tabular}


- Age of participants (intervention group : control group): median (range) in years: 5.1 (0 - 18) : 4.6 (0 18) (age in 1 participant in intervention group and 3 participants in control group unknown)

- Underlying diseases: intervention group: ALL (26), AML (31), MDS (20), other leukaemia (8), neuroblastoma (34), soft tissue sarcoma (9), familial haemophagocytic lymphohistiocytosis (10), osteopetrosis (7), adrenoleukodystrophy (1), others (34), unknown (1); control group: ALL (22), AML (42), MDS (11), other leukaemia (5), neuroblastoma (33), soft tissue sarcoma (8), familial haemophagocytic lymphohistiocytosis (15), osteopetrosis (6), adrenoleukodystrophy (1), others (33), unknown (3)

- Previous treatments: intervention group: stem cell transplant (25), abdominal irradiation (9), gemtuzumab (11), unknown (1); control group: stem cell transplant (23), abdominal irradiation (8), gemtuzumab (5), unknown (3)

- Pre-existing liver dysfunction (intervention group : control group): 41 : 54 (unknown in 1 participant in intervention group and 3 participants in control group)

- Previous history of hepatic VOD (intervention group : control group): information not available

- Performance status before transplant (intervention group : control group): information not available

- Type of transplant: intervention group: allogeneic (122), autologous (53), no transplant (2), unknown (4); control group: allogeneic (117), autologous (55), no transplant (1), unknown (6)

- Donor: intervention group: matched related (35), matched unrelated (55), mismatched related (14), mismatched unrelated (18), autologous (53), no transplant (2), unknown (4); control group: matched related (25), matched unrelated (61), mismatched related (10), mismatched unrelated (21), autologous (55), no transplant (1), unknown (6)

- HLA disparity: intervention group: HLA-matched (90), HLA-mismatched (32), autologous (53), no transplant (2), unknown (4); control group: HLA-matched (86), HLA-mismatched (31), autologous (55), no transplant (1), unknown (6)

- Stem cell source: intervention group: bone marrow (79), peripheral blood stem cell (80), cord blood (16), no transplant (2), unknown (4); control group: bone marrow (81), peripheral blood stem cell (81), cord blood (10), no transplant (1), unknown (6).

- Stem cell manipulation (intervention group : control group): T-cell depletion: $6: 4$ (unknown in 1 participant in intervention group and 3 participants in control group).

- Conditioning regimen: intervention group: intravenous busulfan (80), oral busulfan (46), melphalan (126), cyclophosphamide (84), etoposide (22), fludarabine (34), treosulfan (13), TBI containing regimen (17), others (34), no transplant (2), unknown (4); control group: intravenous busulfan (81), oral busulfan (44), melphalan (114), cyclophosphamide (80), etoposide (25), fludarabine (40), treosulfan (13), TBI containing regimen (18), others (31), no transplant (1), unknown (6)

- GVHD prophylaxis: intervention group: cyclosporin (100), methotrexate (56), ATG (horse) (2), ATG (rabbit) (65), alemtuzumab (9), muromonab-CD3 (11), others (31), no GVHD prophylaxis (53), no transplant (2), unknown (4); control group: cyclosporin (104), methotrexate (65), ATG (horse) (2), ATG (rabbit) (80), alemtuzumab (5), muromonab-CD3 (7), others (28), no GVHD prophylaxis (55), no transplant (1), unknown (6)

Interventions

- Intervention group ( $\mathrm{N}=181$ ): defibrotide $6.25 \mathrm{mg} / \mathrm{kg} /$ dose every 6 hours intravenously over 2 hours from the day of conditioning till day 30

- Control group ( $\mathrm{N}=179)$ : no treatment

\begin{tabular}{ll}
\hline Outcomes & Incidence of hepatic VOD \\
- Overall survival \\
- All-cause mortality at 100 days post-transplant \\
- Mortality attributable to hepatic VOD \\
- Frequency of adverse events
\end{tabular}

\section{Notes}

- Duration of follow-up: 180 days

- Loss to follow-up (intervention group : control group): 10 (1 did not provide consent, 2 had adverse events, 1 transferred to another hospital, 6 unknown) : 10 ( 3 did not provide consent, 3 withdrew consent, 2 had adverse event, 1 had relapse, 1 transferred to another hospital). Data were available for 338 participants (93.9\%) at 30 days, 269 participants (74.7\%) at 100 days, and 173 participants (48.1\%) at 180 days

- Funding source: Gentium SpA and the European Blood and Marrow Transplantation (EBMT) Group 
- Declarations of interest: S Corbacioglu, J Massaro, and R D'Agostino received fees from Gentium for review activities on this report. J Massaro received payment from Gentium for writing and reviewing the report and for writing assistance. S Corbacioglu and C Peters's institutions received grants to their institutions from Gentium and K-W Sykora's institution received a grant from Medac. C Peters had given lectures and was on the speakers bureau for the Center for International Blood and Marrow Transplant Research, Amgen, and Fresenius. S Corbacioglu, J Massaro, and S Matthes-Martin had received support for travel relating to the report from Gentium. S Corbacioglu and J Massaro had received consultancy fees or honorarium from Gentium and C Peters had received such fees from Medac. M Hoyle and $\mathrm{M}$ lacobelli were employees and had stock in Gentium. C Peters had received support for travel, accommodation, and meetings from Amomed and Gentium. All other authors declared that they had no conflicts of interest

\section{Risk of bias}

\begin{tabular}{|c|c|c|}
\hline Bias & Authors' judgement & Support for judgement \\
\hline $\begin{array}{l}\text { Random sequence genera- } \\
\text { tion (selection bias) }\end{array}$ & Low risk & Computer-generated randomisation sequence \\
\hline $\begin{array}{l}\text { Allocation concealment } \\
\text { (selection bias) }\end{array}$ & Low risk & $\begin{array}{l}\text { A data manager centrally assigned eligible participants on the basis of a com- } \\
\text { puter-generated randomisation sequence }\end{array}$ \\
\hline $\begin{array}{l}\text { Blinding of participants } \\
\text { and personnel (perfor- } \\
\text { mance bias) } \\
\text { All outcomes }\end{array}$ & High risk & Neither participants nor study personnel were blinded \\
\hline $\begin{array}{l}\text { Blinding of outcome as- } \\
\text { sessment (detection bias) } \\
\text { All outcomes }\end{array}$ & High risk & Blinding of outcome assessors was not described \\
\hline $\begin{array}{l}\text { Incomplete outcome data } \\
\text { (attrition bias) } \\
\text { All outcomes }\end{array}$ & High risk & Data were available for only $48.1 \%$ of participants by the end of follow-up \\
\hline $\begin{array}{l}\text { Selective reporting (re- } \\
\text { porting bias) }\end{array}$ & Low risk & All outcomes in the protocol were reported \\
\hline Other bias & Low risk & No other bias is evident \\
\hline
\end{tabular}

\section{Demuynck 1995}

\begin{tabular}{ll}
\hline Methods & - Study design: parallel-group randomised controlled trial \\
- Stratification factor: none \\
- Settings: inpatients \\
- Ltudy dates: not reported \\
\hline - Inclusion criteria: people undergoing stem cell transplant \\
- Exclusion criteria: information not available \\
- Number of participants: PGE1 group (47); heparin group (47); enoxaparin group (46) \\
- Number of men: information not available \\
- Age of participants: information not available \\
- Underlying diseases: information not available \\
- Previous treatments: information not available
\end{tabular}


- Pre-existing liver dysfunction: information not available

- Previous history of hepatic VOD: information not available

- Performance status before transplant: information not available

- Type of transplant: PGE1 group: allogeneic (14), autologous (33); heparin group: allogeneic (14), autologous (33); enoxaparin group: allogeneic (15), autologous (31)

- Donor: PGE1 group: allogeneic (14), autologous (33); heparin group: allogeneic (14), autologous (33); enoxaparin group: allogeneic (15), autologous (31)

- HLA disparity: information not available

- Stem cell source: information not available

- Stem cell manipulation: information not available

- Conditioning regimen: information not available

- GVHD prophylaxis (intervention group : control group): information not available

\begin{tabular}{|c|c|}
\hline Interventions & $\begin{array}{l}\text { - PGE1 group ( } \mathrm{N}=47) \text { : prostaglandin E1 } 500 \mathrm{microgram} / \mathrm{kg} / \text { day intravenous infusion } \\
\text { - Heparin group ( } \mathrm{N}=47 \text { ): heparin } 100 \mathrm{units} / \mathrm{kg} / \text { day intravenous infusion } \\
\text { - Enoxaparin group ( } \mathrm{N}=46 \text { ): enoxaparin } 20 \mathrm{mg} / \text { day subcutaneous injection }\end{array}$ \\
\hline Outcomes & $\begin{array}{l}\text { - Incidence of hepatic VOD } \\
\text { - Mortality attributable to hepatic VOD } \\
\text { - Frequency of adverse events }\end{array}$ \\
\hline Notes & $\begin{array}{l}\text { - Duration of follow-up: information not available. } \\
\text { - Loss to follow-up: information not available. } \\
\text { - Funding source: information not available. } \\
\text { - Declarations of interest: information not available. } \\
\text { - Information based on abstract only }\end{array}$ \\
\hline
\end{tabular}

\section{Risk of bias}

\begin{tabular}{|c|c|c|}
\hline Bias & Authors' judgement & Support for judgement \\
\hline $\begin{array}{l}\text { Random sequence genera- } \\
\text { tion (selection bias) }\end{array}$ & Unclear risk & Random sequence generation was not described \\
\hline $\begin{array}{l}\text { Allocation concealment } \\
\text { (selection bias) }\end{array}$ & Unclear risk & Allocation concealment was not described \\
\hline $\begin{array}{l}\text { Blinding of participants } \\
\text { and personnel (perfor- } \\
\text { mance bias) } \\
\text { All outcomes }\end{array}$ & High risk & Neither participants nor study personnel were blinded \\
\hline $\begin{array}{l}\text { Blinding of outcome as- } \\
\text { sessment (detection bias) } \\
\text { All outcomes }\end{array}$ & Unclear risk & Blinding of outcome assessors was not described \\
\hline $\begin{array}{l}\text { Incomplete outcome data } \\
\text { (attrition bias) } \\
\text { All outcomes }\end{array}$ & Unclear risk & Dropout was not described \\
\hline $\begin{array}{l}\text { Selective reporting (re- } \\
\text { porting bias) }\end{array}$ & Unclear risk & $\begin{array}{l}\text { Protocol was not available. It was unclear whether all pre-specified outcomes } \\
\text { were reported }\end{array}$ \\
\hline
\end{tabular}


Demuynck 1995 (Continued)

Other bias Unclear risk
We were not certain whether important baseline characteristics of the participants in different treatment groups were comparable or not. We were also not certain whether different treatment groups received same co-interventions

Essell 1998

$\begin{array}{ll}\text { Methods } & \text { - Study design: parallel-group randomised controlled trial } \\ \text { - Stratification factor: none } \\ \text { - Settings: inpatients } \\ \text { - Study dates: } 24 \text { February } 1992 \text { to } 4 \text { August } 1994 \\ \text { - Location: USA }\end{array}$

Participants

- Inclusion criteria: allogeneic bone marrow transplant from a related donor using busulfan and cyclophosphamide as conditioning

- Exclusion criteria: impaired creatinine clearance $(<50 \mathrm{ml} / \mathrm{min})$, pregnancy, lactation, allergy to bile acids, failure to give informed consent

- Number of participants (intervention group : control group): $35: 32$

- Number of men (intervention group : control group): $22: 20$

- Age of participants (intervention group : control group): mean (range) in years: 38 (22 - 56) : 37 (21 - 56)

- Underlying diseases: Intervention group: AML (5), ALL (3), CML (20), myeloma (3), myelodysplastic syndrome (2), myelofibrosis (0), Castleman disease (1), paroxysmal nocturnal haemoglobinuria (1); Control group: AML (9), ALL (3), CML (12), myeloma (3), myelodysplastic syndrome (1), myelofibrosis (2), Castleman disease (0), paroxysmal nocturnal haemoglobinuria (2)

- Previous treatments (intervention group : control group): more than 1 cytotoxic regimen: $10: 10$

- Pre-existing liver dysfunction (intervention group : control group): elevated AST: $3: 3$

- Previous history of hepatic VOD (intervention group : control group): information not available

- Performance status before transplant (intervention group : control group): mean Karnofsky performance score (range): $85(70$ - 100): 83 (70 - 100)

- Type of transplant: all participants received allogeneic bone marrow transplant from a related donor

- Donor: all participants received allogeneic transplant from a related donor

- HLA disparity (intervention group : control group): information not available

- Stem cell source: all participants received bone marrow

- Stem cell manipulation (intervention group : control group): information not available

- Conditioning regimen: all participants received busulfan and cyclophosphamide

- GVHD prophylaxis: all participants received methotrexate and cyclosporin

Interventions

- Intervention group ( $\mathrm{N}=35$ ): ursodiol $300 \mathrm{mg}$ twice daily orally (body weight $<90 \mathrm{~kg}$ ), or $300 \mathrm{mg} / 600$ $\mathrm{mg}$ twice daily (body weight $>90 \mathrm{~kg}$ ), from before start of conditioning till 80 days post-transplant

- Control group ( $\mathrm{N}=32$ ): placebo capsules with same appearance twice daily orally from before start of conditioning till 80 days post-transplant

$\begin{array}{ll}\text { Outcomes } & \text { Incidence of hepatic VOD } \\ \text { - Overall survival } \\ \text { - All-cause mortality at } 100 \text { days post-transplant } \\ \text { - Mortality attributable to hepatic VOD } \\ \text { - Frequency of adverse events }\end{array}$

Notes

- Duration of follow-up: 1 year post-transplant

- Loss to follow-up (intervention group : control group): 1 (reason not provided) : 0

- Donor-recipient blood group mismatch was less frequent in the intervention group (23\%) compared to the control group (50\%). Methexate was truncated less frequently in the intervention group (3\%) compared to the control group (19\%) 
Essell 1998 (Continued)

- Funding source: Summit Pharmaceuticals supplied the study drug and placebo

- Declarations of interest: No financial assistance was provided

\section{Risk of bias}

\begin{tabular}{lll}
\hline Bias & Authors' judgement & Support for judgement \\
\hline $\begin{array}{l}\text { Random sequence genera- } \\
\text { tion (selection bias) }\end{array}$ & Low risk & $\begin{array}{l}\text { Cards labelled "ursodiol" and "placebo" were placed in sealed opaque en- } \\
\text { velops and then randomised and given consecutive numbers. Randomization } \\
\text { was done by pharmacist not involved in clinical care of patients. }\end{array}$ \\
\hline $\begin{array}{l}\text { Allocation concealment } \\
\text { (selection bias) }\end{array}$ & Low risk & Allocation cards were put into sealed, opaque, numbered envelops \\
\hline $\begin{array}{l}\text { Blinding of participants } \\
\text { and personnel (perfor- } \\
\begin{array}{l}\text { mance bias) } \\
\text { All outcomes }\end{array}\end{array}$ & Low risk & Both participants and personnel were blinded \\
\hline
\end{tabular}

\begin{tabular}{|c|c|c|}
\hline $\begin{array}{l}\text { Blinding of outcome as- } \\
\text { sessment (detection bias) } \\
\text { All outcomes }\end{array}$ & Low risk & Outcome assessors were blinded \\
\hline $\begin{array}{l}\text { Incomplete outcome data } \\
\text { (attrition bias) } \\
\text { All outcomes }\end{array}$ & Low risk & $\begin{array}{l}\text { There was only } 1 \text { dropout ( } 3 \%) \text { in the intervention group and unlikely to have } \\
\text { significant influence on the overall outcome }\end{array}$ \\
\hline $\begin{array}{l}\text { Selective reporting (re- } \\
\text { porting bias) }\end{array}$ & Unclear risk & $\begin{array}{l}\text { Protocol was not available. It was unclear whether all pre-specified outcomes } \\
\text { were reported }\end{array}$ \\
\hline Other bias & High risk & $\begin{array}{l}\text { Donor-recipient blood group mismatch was less frequent in the intervention } \\
\text { group compared to the control group. Diagnosis of CML was more frequent } \\
\text { in the intervention group compared to the control group. Hence the } 2 \text { groups } \\
\text { might not be comparable at baseline. Methexate was truncated less frequent- } \\
\text { ly in the intervention group (3\%) compared to the control group (19\%). The dif- } \\
\text { ference in this co-intervention might cause bias }\end{array}$ \\
\hline
\end{tabular}

Jung 2005

\begin{tabular}{ll}
\hline Methods & Study design: parallel-group randomised controlled trial \\
- Stratification factor: none \\
- Settings: inpatients \\
- Study dates: not reported \\
- Location: Korea \\
\hline - Inclusion criteria: people undergoing stem cell transplant \\
- Exclusion criteria: information not available \\
- Number of participants (intervention group : control group): 14 : 16 \\
- Number of men (intervention group : control group): information not available \\
- Age of participants (intervention group : control group): information not available \\
- Underlying diseases: both groups: AML (9), ALL (4), acute biphenotypic leukaemia (2), CML (3), small \\
\\
lymphocytic leukaemia (1), myeloma (2), myelodysplastic syndrome (1), non-Hodgkin lymphoma (6), \\
- Hodgkin lymphoma (1), aplastic anaemia (1) \\
- Previous treatments (intervention group : control group): information not available.
\end{tabular}

Interventions for prophylaxis of hepatic veno-occlusive disease in people undergoing haematopoietic stem cell transplantation (Review) 
Jung 2005 (Continued)

- Previous history of hepatic VOD (intervention group : control group): information not available

- Performance status before transplant (intervention group : control group): information not available

- Type of transplant: both groups: allogeneic (17), autologous (13)

- Donor: both groups: sibling (13), unrelated (4), autologous (13)

- HLA disparity (intervention group : control group): information not available

- Stem cell source: both groups: bone marrow or peripheral blood stem cells (29), cord blood (1)

- Stem cell manipulation (intervention group : control group): information not available

- Conditioning regimen (intervention group : control group): information not available

- GVHD prophylaxis (intervention group : control group): information not available

Interventions
- Intervention group ( $\mathrm{N}=14)$ : antithrombin III 1000 units twice daily intravenously from day 1 till day 14 post-transplant and heparin 5 units/kg/hour intravenous infusion from day 1 till day 21 post-transplant or discharge after transplant

- Control group ( $\mathrm{N}=16)$ : heparin 5 units/kg/hour intravenous infusion from day 1 till day 21 post-transplant or discharge after transplant

\begin{tabular}{ll}
\hline Outcomes & Incidence of hepatic VOD \\
& - Mortality attributable to hepatic VOD \\
& - Frequency of adverse event (bleeding) \\
\hline Notes & Duration of follow-up: information not available \\
- Loss to follow-up (intervention group : control group): information not available \\
- Declarations of interest: information not available \\
- Information based on abstract only
\end{tabular}

\section{Risk of bias}

\begin{tabular}{lll}
\hline Bias & Authors' judgement & Support for judgement \\
\hline $\begin{array}{l}\text { Random sequence genera- } \\
\text { tion (selection bias) }\end{array}$ & Unclear risk & Random sequence generation was not described \\
\hline $\begin{array}{l}\text { Allocation concealment } \\
\text { (selection bias) }\end{array}$ & Unclear risk & Allocation concealment was not described \\
\hline $\begin{array}{l}\text { Blinding of participants } \\
\text { and personnel (perfor- } \\
\text { mance bias) }\end{array}$ & High risk & Neither participants nor study personnel were blinded \\
All outcomes & \\
\hline
\end{tabular}

\begin{tabular}{|c|c|c|}
\hline $\begin{array}{l}\text { Blinding of outcome as- } \\
\text { sessment (detection bias) } \\
\text { All outcomes }\end{array}$ & Unclear risk & Blinding of outcome assessors was not described \\
\hline
\end{tabular}

\begin{tabular}{lll}
\hline $\begin{array}{l}\text { Incomplete outcome data } \\
\text { (attrition bias) } \\
\text { All outcomes }\end{array}$ & Unclear risk & Dropout was not described. \\
\hline $\begin{array}{l}\text { Selective reporting (re- } \\
\text { porting bias) }\end{array}$ & Unclear risk & $\begin{array}{l}\text { Protocol was not available. It was unclear whether all pre-specified outcomes } \\
\text { were reported. }\end{array}$ \\
\hline Other bias & Unclear risk & $\begin{array}{l}\text { We were not certain whether important baseline characteristics of the partici- } \\
\text { pants in different treatment groups were comparable or not. We were also not } \\
\text { certain whether different treatment groups received same co-interventions. }\end{array}$
\end{tabular}


Lee 1996

\begin{tabular}{|c|c|}
\hline Methods & $\begin{array}{l}\text { - Study design: parallel-group randomised controlled trial } \\
\text { - Stratification factor: none } \\
\text { - Settings: inpatients } \\
\text { - Study dates: not reported } \\
\text { - Location: Singapore }\end{array}$ \\
\hline Participants & $\begin{array}{l}\text { - Inclusion criteria: people with haematological malignancies undergoing bone marrow transplant } \\
\text { - Exclusion criteria: information not available } \\
\text { - Number of participants (intervention group : control group): } 23: 22 \\
\text { - Number of men (intervention group : control group): information not available } \\
\text { - Age of participants (intervention group : control group): information not available } \\
\text { - Underlying diseases: all participants had haematological malignancies } \\
\text { - Previous treatments (intervention group : control group): information not available } \\
\text { - Pre-existing liver dysfunction (intervention group : control group): information not available } \\
\text { - Previous history of hepatic VOD (intervention group : control group): information not available } \\
\text { - Performance status before transplant (intervention group : control group): information not available } \\
\text { - Type of transplant (intervention group : control group): information not available } \\
\text { - Donor (intervention group : control group): information not available } \\
\text { - HLA disparity (intervention group : control group): information not available } \\
\text { - Stem cell source: all participants received bone marrow } \\
\text { - Stem cell manipulation (intervention group : control group): information not available } \\
\text { - Conditioning regimen (intervention group : control group): information not available } \\
\text { - GVHD prophylaxis (intervention group : control group): information not available }\end{array}$ \\
\hline Interventions & $\begin{array}{l}\text { - Intervention group }(\mathrm{N}=23) \text { : } \text { nadroparin calcium } \\
\text { - } \text { Control group }(\mathrm{N}=22) \text { : } \text { no nadroparin calcium }\end{array}$ \\
\hline Outcomes & $\begin{array}{l}\text { - Incidence of hepatic VOD } \\
\text { - Frequency of adverse event (bleeding) }\end{array}$ \\
\hline Notes & $\begin{array}{l}\text { - Duration of follow-up: information not available } \\
\text { - Loss to follow-up (intervention group : control group): information not available } \\
\text { - Funding source: information not available } \\
\text { - Declarations of interest: information not available } \\
\text { - Information based on abstract only }\end{array}$ \\
\hline
\end{tabular}

\section{Risk of bias}

\begin{tabular}{lll}
\hline Bias & Authors' judgement & Support for judgement \\
\hline $\begin{array}{l}\text { Random sequence genera- } \\
\text { tion (selection bias) }\end{array}$ & Unclear risk & Random sequence generation was not described \\
\hline $\begin{array}{l}\text { Allocation concealment } \\
\text { (selection bias) }\end{array}$ & Unclear risk & Allocation concealment was not described \\
\hline $\begin{array}{l}\text { Blinding of participants } \\
\text { and personnel (perfor- } \\
\text { mance bias) }\end{array}$ & High risk & Neither participants nor study personnel were blinded \\
All outcomes & \\
\hline
\end{tabular}


Lee 1996 (Continued)

Blinding of outcome as- Unclear risk Blinding of outcome assessors was not described sessment (detection bias)

All outcomes

\begin{tabular}{lll}
\hline $\begin{array}{l}\text { Incomplete outcome data } \\
\text { (attrition bias) } \\
\text { All outcomes }\end{array}$ & Unclear risk & Dropout was not described \\
\hline $\begin{array}{l}\text { Selective reporting (re- } \\
\text { porting bias) }\end{array}$ & Unclear risk & $\begin{array}{l}\text { Protocol was not available. It was unclear whether all pre-specified outcomes } \\
\text { were reported }\end{array}$ \\
\hline Other bias & Unclear risk & $\begin{array}{l}\text { We were not certain whether important baseline characteristics of the partici- } \\
\text { pants in different treatment groups were comparable or not. We were also not } \\
\text { certain whether different treatment groups received same co-interventions }\end{array}$ \\
\hline
\end{tabular}

Marsa-Vila 1991

\begin{tabular}{|c|c|}
\hline Methods & $\begin{array}{l}\text { - Study design: parallel-group randomised controlled trial } \\
\text { - Stratification factor: none } \\
\text { - Settings: inpatients } \\
\text { - Study dates: October } 1984 \text { to March } 1989 \\
\text { - Location: France }\end{array}$ \\
\hline Participants & $\begin{array}{l}\text { - Inclusion criteria: people with haematological malignancies and solid tumours undergoing autolo- } \\
\text { - Eous bone marrow transplant } \\
\text { - Number of participants (intervention group : control group): } 52: 46 \\
\text { - Number of men (intervention group : control group): information not available } \\
\text { - Age of participants (intervention group : control group): information not available } \\
\text { - Underlying diseases: haematological malignancies or solid tumours } \\
\text { - Previous treatments (intervention group : control group): information not available } \\
\text { - Pre-existing liver dysfunction (intervention group : control group): information not available } \\
\text { - Previous history of hepatic VOD (intervention group : control group): information not available } \\
\text { - Performance status before transplant (intervention group : control group): information not available } \\
\text { - Type of transplant: both groups: autologous bone marrow transplant } \\
\text { - Donor: both groups: autologous } \\
\text { - HLA disparity: both groups: autologous } \\
\text { - Stem cell source: all participants received bone marrow } \\
\text { - Stem cell manipulation (intervention group : control group): information not available } \\
\text { - Conditioning regimen (intervention group : control group): information not available } \\
\text { - GVHD prophylaxis: not applicable }\end{array}$ \\
\hline Interventions & $\begin{array}{l}\text { - Intervention group }(\mathrm{N}=52) \text { : heparin } 1 \mathrm{mg} / \mathrm{kg} / \text { day intravenous infusion from day } 0 \text { to haematological } \\
\text { reconstitution and discharge } \\
\text { - Control group }(\mathrm{N}=46) \text { : no heparin }\end{array}$ \\
\hline Outcomes & - Incidence of hepatic VOD \\
\hline Notes & $\begin{array}{l}\text { - Duration of follow-up: information not available } \\
\text { - Loss to follow-up (intervention group : control group): information not available } \\
\text { - Funding source: Consejeria de Educacion of the Canary Islands Government, Spain } \\
\text { - Declarations of interest: information not available }\end{array}$ \\
\hline
\end{tabular}


Marsa-Vila 1991 (Continued)

Risk of bias

\begin{tabular}{|c|c|c|}
\hline Bias & Authors' judgement & Support for judgement \\
\hline $\begin{array}{l}\text { Random sequence genera- } \\
\text { tion (selection bias) }\end{array}$ & Unclear risk & Random sequence generation was not described \\
\hline $\begin{array}{l}\text { Allocation concealment } \\
\text { (selection bias) }\end{array}$ & Unclear risk & Allocation concealment was not described \\
\hline $\begin{array}{l}\text { Blinding of participants } \\
\text { and personnel (perfor- } \\
\text { mance bias) } \\
\text { All outcomes }\end{array}$ & High risk & Neither participants nor study personnel were blinded \\
\hline $\begin{array}{l}\text { Blinding of outcome as- } \\
\text { sessment (detection bias) } \\
\text { All outcomes }\end{array}$ & Unclear risk & Blinding of outcome assessors was not described \\
\hline $\begin{array}{l}\text { Incomplete outcome data } \\
\text { (attrition bias) } \\
\text { All outcomes }\end{array}$ & Unclear risk & Dropout was not described \\
\hline $\begin{array}{l}\text { Selective reporting (re- } \\
\text { porting bias) }\end{array}$ & Unclear risk & $\begin{array}{l}\text { Protocol was not available. It was unclear whether all pre-specified outcomes } \\
\text { were reported }\end{array}$ \\
\hline Other bias & Unclear risk & $\begin{array}{l}\text { We were not certain whether important baseline characteristics of the partici- } \\
\text { pants in different treatment groups were comparable or not. We were also not } \\
\text { certain whether different treatment groups received same co-interventions }\end{array}$ \\
\hline
\end{tabular}

Matsumoto 2007

\begin{tabular}{|c|c|}
\hline Methods & $\begin{array}{l}\text { - Study design: parallel-group randomised controlled trial } \\
\text { - Stratification factor: stratified by age to } 2 \text { groups: } \leq 18 \text { years and > } 18 \text { years } \\
\text { - Settings: inpatients } \\
\text { - Study dates: April } 2001 \text { to March } 2003 \\
\text { - Location: Japan }\end{array}$ \\
\hline Participants & $\begin{array}{l}\text { - Inclusion criteria: allogeneic transplant and } 1 \text { of the following: } 1 \text {. intensified conditioning regimen, } 2 . \\
\text { - } \text { Excond transplant, } 3 \text {. liver dysfunction, } 4 \text {. intensified chemotherapy until just before transplant } \\
\text { - Number of participants (intervention group : control group): } 24: 23 \\
\text { - Number of men (intervention group : control group): } 15: 16 \text { (gender in } 1 \text { participant in intervention } \\
\text { group and } 3 \text { participants in control group unknown) } \\
\text { - Age of participants (intervention group: control group): range in years: } 1 \text { - } 54: 1 \text { - } 64 \text { (age in } 1 \text { participant } \\
\text { in intervention group and } 3 \text { participants in control group unknown) } \\
\text { - Underlying diseases: intervention group: } \mathrm{ALL}(4), \mathrm{AML}(8), \mathrm{MDS}(4), \mathrm{CML}(3), \mathrm{NHL}(2), \text { aplastic anaemia } \\
\text { (1), Wiskott Aldrich syndrome (1), unknown (1); control group: } \mathrm{ALL}(8), \mathrm{AML}(5), \mathrm{MDS}(2), \mathrm{CML}(1), \mathrm{NK}- \\
\text { leukaemia (1), NHL (1); Hodgkin lymphoma (1), chronic active EBV infection (1), unknown (3) } \\
\text { - Previous treatments (intervention group : control group): information not available } \\
\text { - Pre-existing liver dysfunction (intervention group : control group): information not available } \\
\text { - Previous history of hepatic VOD (intervention group : control group): information not available } \\
\text { - Performance status before transplant (intervention group : control group): information not available } \\
\text { - Type of transplant: both groups: allogeneic }\end{array}$ \\
\hline
\end{tabular}


- Donor: intervention group: related (8), unrelated (15), unknown (1); control group: related (6), unrelated (14), unknown (3)

- HLA disparity (intervention group : control group): information not available

- Stem cell source: intervention group: bone marrow (7), peripheral blood stem cell (5), cord blood (11), unknown (1); control group: bone marrow (9), peripheral blood stem cell (5), cord blood (6), unknown (3)

- Stem cell manipulation (intervention group : control group): information not available

- Conditioning regimen: intervention group: myeloablative (20), non-myeloablative (3), unknown (1); control group: myeloablative (17), non-myeloablative (3), unknown (3)

- GVHD prophylaxis: intervention group: cyclosporin/methotrexate (5), tacrolimus/methotrexate (7), tacrolimus/methotrexate/prednisolone (1), cyclosporin (6), tacrolimus (4), unknown (1); control group: cyclosporin/methotrexate (11), tacrolimus/methotrexate (2), cyclosporin (1), tacrolimus (5), none (1), unknown (3)

\begin{tabular}{ll}
\hline Interventions & Intervention group (N=24): fresh frozen plasma intravenous infusion twice weekly from conditioning \\
& till day 28. Volume: <10 kg: $80 \mathrm{ml} ; 10-20 \mathrm{~kg}: 160 \mathrm{ml} ; 20-30 \mathrm{~kg}: 240 \mathrm{ml} ; 30-40 \mathrm{~kg}: 320 \mathrm{ml} ;>40 \mathrm{~kg}: 400 \mathrm{ml}$ \\
- & Control group (N=23): no fresh frozen plasma \\
\hline Outcomes & Incidence of hepatic VOD \\
\hline Notes & Duration of follow-up: 28 days \\
- Loss to follow-up (intervention group : control group): 1 (could not undergo transplant because of \\
poor physical condition): 3 (could not undergo transplant because of poor physical condition) \\
- Funding source: Ministry of Education, Culture, Sports, Science and Technology; and Ministry of \\
Health, Labour and Welfare of Japan \\
- Declarations of interest: information not available
\end{tabular}

\section{Risk of bias}

\begin{tabular}{lll}
\hline Bias & Authors' judgement & Support for judgement \\
\hline $\begin{array}{l}\text { Random sequence genera- } \\
\text { tion (selection bias) }\end{array}$ & Unclear risk & Random sequence generation was not described \\
\hline $\begin{array}{l}\text { Allocation concealment } \\
\text { (selection bias) }\end{array}$ & Unclear risk & Allocation concealment was not described \\
\hline $\begin{array}{l}\text { Blinding of participants } \\
\text { and personnel (perfor- } \\
\text { mance bias) }\end{array}$ & High risk & Neither participants nor study personnel were blinded \\
All outcomes & & \\
\hline
\end{tabular}

\begin{tabular}{lll}
$\begin{array}{l}\text { Blinding of outcome as- } \\
\text { sessment (detection bias) } \\
\text { All outcomes }\end{array}$ & Unclear risk & Blinding of outcome assessors was not described \\
\hline $\begin{array}{l}\text { Incomplete outcome data } \\
\text { (attrition bias) }\end{array}$ & High risk & $\begin{array}{l}\text { Dropouts occurred in 4\% of intervention group and 13\% of control group and } \\
\text { might cause bias }\end{array}$ \\
\hline All outcomes & & \begin{tabular}{l} 
migh \\
\hline
\end{tabular}
\end{tabular}

All outcomes

\begin{tabular}{|c|c|c|}
\hline $\begin{array}{l}\text { Selective reporting (re- } \\
\text { porting bias) }\end{array}$ & Unclear risk & $\begin{array}{l}\text { Protocol was not available. It was unclear whether all pre-specified outcomes } \\
\text { were reported }\end{array}$ \\
\hline Other bias & High risk & $\begin{array}{l}\text { Some baseline characteristics of both groups were quite different and there- } \\
\text { fore the } 2 \text { groups might not be comparable. These included a lower propor- } \\
\text { tion of ALL and higher proportion of cord blood transplant in the intervention } \\
\text { group compared with the control group. There were more participants receiv- }\end{array}$ \\
\hline
\end{tabular}




\begin{tabular}{|c|c|}
\hline Methods & $\begin{array}{l}\text { - Study design: parallel-group randomised controlled trial } \\
\text { - Stratification factor: none } \\
\text { - Settings: inpatients } \\
\text { - Study dates: June } 1996 \text { to February } 1998 \\
\text { - Location: Japan }\end{array}$ \\
\hline Participants & $\begin{array}{l}\text { - Inclusion criteria: people undergoing stem cell transplant } \\
\text { - Exclusion criteria: information not available } \\
\text { - Number of participants (intervention group : control group): } 71: 65 \\
\text { - Number of men (intervention group : control group): } 40: 30 \text { (gender in } 4 \text { participants in intervention } \\
\text { group unknown) } \\
\text { - Age of participants (intervention group: control group): mean in years: } 34.5: 35.7 \text { (age in } 4 \text { participants } \\
\text { in intervention group unknown) } \\
\text { - Underlying diseases: intervention group: ALL (15), acute non-lymphocytic leukaemia (23), MDS (4), } \\
\text { CML (15), lymphoma (3), aplastic anaemia (3), others (4), unknown (4); control group: ALL (12), acute } \\
\text { non-lymphocytic leukaemia (19), MDS (4), CML (15), lymphoma (8), aplastic anaemia (5), others (2) } \\
\text { - Previous treatments (intervention group : control group): information not available } \\
\text { - Pre-existing liver dysfunction (intervention group: control group): information not available } \\
\text { - Previous history of hepatic VOD (intervention group: control group): information not available } \\
\text { - Performance status before transplant (intervention group: control group): information not available } \\
\text { - Type of transplant: intervention group: allogeneic (61), autologous (6), unknown (4); control group: } \\
\text { allogeneic (56), autologous (9) } \\
\text { - Donor: intervention group: related (39), unrelated (22), autologous (6), unknown (4); control group: } \\
\text { related (31), unrelated (25), autologous (9) } \\
\text { - HLA disparity: intervention group: genotypically identical (29), phenotypically identical (8), mis- } \\
\text { matched (2), unknown (4); control group: genotypically identical (27), phenotypically identical (4), } \\
\text { mismatched (0) } \\
\text { - Stem cell source (intervention group : control group): information not available } \\
\text { - Stem cell manipulation (intervention group : control group): information not available } \\
\text { - Conditioning regimen: intervention group: chemotherapy only (23), chemotherapy and TBI (34), } \\
\text { chemotherapy and TLI (10), unknown (4); control group: chemotherapy only (18), chemotherapy and } \\
\text { TBI (37), chemotherapy and TLI (10) } \\
\text { - GVHD prophylaxis: intervention group: cyclosporin/methotrexate (60), tacrolimus/methotrexate (0), } \\
\text { cyclosporin (1), unknown (4); control group: cyclosporin/methotrexate (53), tacrolimus/methotrexate } \\
\text { (1), cyclosporin ( } 2 \text { ) }\end{array}$ \\
\hline
\end{tabular}

Interventions Intervention group $(\mathrm{N}=71)$ : ursodeoxycholic acid $600 \mathrm{mg} /$ day orally from day -21 till day 80

- Control group ( $\mathrm{N}=65)$ : no ursodeoxycholic acid

\begin{tabular}{ll}
\hline Outcomes & Incidence of hepatic VOD \\
- All-cause mortality \\
- Mortality attributable to hepatic VOD \\
- Frequency of adverse events \\
\hline Notes & Duration of follow-up: 24 weeks \\
& Loss to follow-up (intervention group : control group): $4(1$ died due to regimen-related toxicity, 1 did \\
& not undergo transplant, 2 could not retrieve data sheets): 0 \\
\hline
\end{tabular}


Ohashi 2000 (Continued)

- Funding source: information not available

- Declarations of interest: information not available

\section{Risk of bias}

\begin{tabular}{|c|c|c|}
\hline Bias & Authors' judgement & Support for judgement \\
\hline $\begin{array}{l}\text { Random sequence genera- } \\
\text { tion (selection bias) }\end{array}$ & Unclear risk & Random sequence generation was not described \\
\hline $\begin{array}{l}\text { Allocation concealment } \\
\text { (selection bias) }\end{array}$ & Unclear risk & Allocation concealment was not described \\
\hline $\begin{array}{l}\text { Blinding of participants } \\
\text { and personnel (perfor- } \\
\text { mance bias) } \\
\text { All outcomes }\end{array}$ & High risk & Neither participants nor study personnel were blinded \\
\hline $\begin{array}{l}\text { Blinding of outcome as- } \\
\text { sessment (detection bias) } \\
\text { All outcomes }\end{array}$ & Unclear risk & Blinding of outcome assessors was not described \\
\hline $\begin{array}{l}\text { Incomplete outcome data } \\
\text { (attrition bias) } \\
\text { All outcomes }\end{array}$ & High risk & $\begin{array}{l}\text { Dropouts occurred in } 6 \% \text { of intervention group and none of control group and } \\
\text { might cause bias }\end{array}$ \\
\hline $\begin{array}{l}\text { Selective reporting (re- } \\
\text { porting bias) }\end{array}$ & Unclear risk & $\begin{array}{l}\text { Protocol was not available. It was unclear whether all pre-specified outcomes } \\
\text { were reported }\end{array}$ \\
\hline Other bias & High risk & $\begin{array}{l}\text { Some baseline characteristics of both groups were quite different and there- } \\
\text { fore the } 2 \text { groups might not be comparable. These included a higher propor- } \\
\text { tion of men and lower proportion of lymphoma in the intervention group com- } \\
\text { pared with the control group }\end{array}$ \\
\hline
\end{tabular}

\begin{tabular}{ll}
\hline Methods & Study design: parallel-group randomised controlled trial \\
- Stratification factor: stratified by type of transplant to 2 groups: allogeneic and autologous \\
- Settings: inpatients \\
- Study dates: August 1992 to December 1993 \\
- Location: Israel \\
- Inclusion criteria: people above 15 years with malignant disease undergoing stem cell transplant \\
- Exclusion criteria: pre-transplant platelet < 20x109/L, history of major thrombotic or bleeding event, \\
Participants \\
- Number of participants (intervention group : control group): $28: 33$ \\
- Number of men (intervention group : control group): $14: 11$ \\
- Age of participants (intervention group : control group): mean (SD) in years: 40 (9.9): 34 (10.2) \\
- Underlying diseases: intervention group: ALL (2), AML (3), MDS (2), CML (3), CLL (1), NHL (9), Hodgkin \\
\\
lymphoma (2), multiple myeloma (1), solid tumour (4); control group: ALL (3), AML (6), MDS (0), CML \\
(9), CLL (0), NHL (7), Hodgkin lymphoma (2), multiple myeloma (1), solid tumour (6) \\
- Previous treatments (intervention group : control group): information not available \\
- Pre-existing liver dysfunction (intervention group : control group): elevated bilirubin: $1: 2$ \\
- Previous history of hepatic VOD (intervention group : control group): information not available
\end{tabular}


- Performance status before transplant (intervention group : control group): information not available

- Type of transplant: intervention group: allogeneic (8), autologous (20); control group: allogeneic (16), autologous (17)

- Donor: (intervention group : control group): information not available

- HLA disparity: (intervention group : control group): information not available

- Stem cell source (intervention group : control group): information not available

- Stem cell manipulation (intervention group : control group): information not available

- Conditioning regimen: intervention group: TECAM (12), CTEM (4), ECYM and TBI (4), ECYM and TBI and TLI (5), Bu-T-CY (2), mitoxantrone and TBI (1); control group: TECAM (7), CTEM (6), ECYM and TBI (9), ECYM and TBI and TLI (6), Bu-T-CY (4), mitoxantrone and TBI (1)

- GVHD prophylaxis (intervention group : control group): information not available

\begin{tabular}{ll}
\hline Interventions & $\begin{array}{l}\text { Intervention group ( } \mathrm{N}=28 \text { ): enoxaparin } 40 \text { mg daily by subcutaneous injection to abdominal wall from } \\
\text { day }-1 \text { till discharge or day } 40 \\
\text { - Control group ( } \mathrm{N}=33 \text { ): placebo (normal saline) }\end{array}$ \\
\hline Outcomes & $\begin{array}{l}\text { Frequencies of hyperbilirubinaemia, hepatic enlargement, right upper quadrant abdominal pain, as- } \\
\text { cites, and weight gain } \\
\text { - Frequency of adverse event (bleeding) }\end{array}$ \\
\hline Notes & Duration of follow-up: information not available \\
- Loss to follow-up (intervention group : control group): $0: 0$ \\
- Funding source: Robert A. Rosenblum Research Fund \\
Declarations of interest: information not available
\end{tabular}

\section{Risk of bias}

\begin{tabular}{|c|c|c|}
\hline Bias & Authors' judgement & Support for judgement \\
\hline $\begin{array}{l}\text { Random sequence genera- } \\
\text { tion (selection bias) }\end{array}$ & Unclear risk & Random sequence generation was not described \\
\hline $\begin{array}{l}\text { Allocation concealment } \\
\text { (selection bias) }\end{array}$ & Unclear risk & Allocation concealment was not described \\
\hline $\begin{array}{l}\text { Blinding of participants } \\
\text { and personnel (perfor- } \\
\text { mance bias) } \\
\text { All outcomes }\end{array}$ & Low risk & Both participants and study personnel were blinded \\
\hline $\begin{array}{l}\text { Blinding of outcome as- } \\
\text { sessment (detection bias) } \\
\text { All outcomes }\end{array}$ & Low risk & Outcome assessors were blinded \\
\hline $\begin{array}{l}\text { Incomplete outcome data } \\
\text { (attrition bias) } \\
\text { All outcomes }\end{array}$ & Low risk & There was no dropout \\
\hline $\begin{array}{l}\text { Selective reporting (re- } \\
\text { porting bias) }\end{array}$ & Unclear risk & $\begin{array}{l}\text { Protocol was not available. It was unclear whether all pre-specified outcomes } \\
\text { were reported }\end{array}$ \\
\hline Other bias & High risk & $\begin{array}{l}\text { Some baseline characteristics of both groups were quite different and there- } \\
\text { fore the } 2 \text { groups might not be comparable. These included a higher propor- } \\
\text { tion of men and lower proportion of chronic myeloid leukaemia and allogene- } \\
\text { ic stem cell transplant in the intervention group compared with the control } \\
\text { group. The participants in the intervention group also had a higher mean age }\end{array}$ \\
\hline
\end{tabular}


Park 2002

\begin{tabular}{|c|c|}
\hline Methods & $\begin{array}{l}\text { - Study design: parallel-group randomised controlled trial } \\
\text { - Stratification factor: none } \\
\text { - Settings: inpatients } \\
\text { - Study dates: February } 1996 \text { to January } 2001 \\
\text { - Location: Korea }\end{array}$ \\
\hline Participants & $\begin{array}{l}\text { - Inclusion criteria: adults undergoing stem cell transplant } \\
\text { - Exclusion criteria: life-threatening gastrointestinal or central nervous system bleeding within } 2 \\
\text { months prior to stem cell transplant, history of allergic reaction to either heparin or ursodiol } \\
\text { - Number of participants (intervention group : control group): } 82: 83 \\
\text { - Number of men (intervention group : control group): } 41: 40 \\
\text { - Age of participants (intervention group : control group): median in years: } 39 \text { : } 38 \\
\text { - Underlying diseases: intervention group: acute leukaemia ( } 23), \mathrm{CML}(9), \text { lymphoma (14), solid tumour } \\
\text { (15), aplastic anaemia (9), others (12); control group: acute leukaemia (32), CML (12), lymphoma (6), } \\
\text { - solid tumour (18), aplastic anaemia (6), others (9) } \\
\text { - Previous treatments (intervention group : control group): information not available } \\
\text { - Pre-existing liver dysfunction (intervention group : control group): information not available } \\
\text { - Previous history of hepatic VOD (intervention group : control group): information not available } \\
\text { - Performance status before transplant (intervention group : control group): information not available } \\
\text { - Type of transplant: intervention group: allogeneic (38), autologous (44); control group: allogeneic (43), } \\
\text { autologous (40) } \\
\text { - Donor: (intervention group : control group): information not available } \\
\text { - HLA disparity: (intervention group : control group): information not available } \\
\text { - Stem cell source (intervention group : control group): information not available } \\
\text { - Stem cell manipulation (intervention group : control group): information not available } \\
\text { - Conditioning regimen: intervention group: busulfan and cyclophosphamide (13), TBI containing reg- } \\
\text { imen (27), others (42); control group: busulfan and cyclophosphamide (16), TBI containing regimen } \\
\text { (31), others (36) } \\
\text { - GVHD prophylaxis (intervention group: control group): information not available }\end{array}$ \\
\hline
\end{tabular}

Interventions

- Intervention group $(\mathrm{N}=82)$ : heparin 5 units $/ \mathrm{kg} /$ hour by continuous intravenous infusion and ursodiol $300 \mathrm{mg}$ every 12 hours orally from 12 - 24 hours before conditioning till discharge or day 30

- Control group $(\mathrm{N}=83)$ : heparin alone

\begin{tabular}{ll}
\hline Outcomes & Incidence of hepatic VOD \\
- Overall survival \\
- All-cause mortality at 100 days post-transplant \\
- Mortality attributable to hepatic VOD \\
- Frequency of adverse event (bleeding) \\
\hline Notes \\
- Duration of follow-up: information not available \\
- Funding source: information not available \\
- Declarations of interest: information not available $0: 0$
\end{tabular}

\section{Risk of bias}

\begin{tabular}{lll}
\hline Bias & Authors' judgement & Support for judgement \\
\hline $\begin{array}{l}\text { Random sequence genera- } \\
\text { tion (selection bias) }\end{array}$ & Unclear risk & Random sequence generation was not described \\
\hline
\end{tabular}


Park 2002 (Continued)

$\begin{aligned} & \text { Allocation concealment } \\ & \text { (selection bias) }\end{aligned} \quad$ Unclear risk

\begin{tabular}{|c|c|c|}
\hline $\begin{array}{l}\text { Blinding of participants } \\
\text { and personnel (perfor- } \\
\text { mance bias) } \\
\text { All outcomes }\end{array}$ & High risk & Neither participants nor study personnel were blinded \\
\hline $\begin{array}{l}\text { Blinding of outcome as- } \\
\text { sessment (detection bias) } \\
\text { All outcomes }\end{array}$ & Unclear risk & Blinding of outcome assessors was not described \\
\hline $\begin{array}{l}\text { Incomplete outcome data } \\
\text { (attrition bias) } \\
\text { All outcomes }\end{array}$ & Low risk & There was no dropout \\
\hline $\begin{array}{l}\text { Selective reporting (re- } \\
\text { porting bias) }\end{array}$ & Unclear risk & $\begin{array}{l}\text { Protocol was not available. It was unclear whether all pre-specified outcomes } \\
\text { were reported }\end{array}$ \\
\hline Other bias & High risk & $\begin{array}{l}\text { Some baseline characteristics of both groups were quite different and there- } \\
\text { fore the } 2 \text { groups might not be comparable. These included a higher propor- } \\
\text { tion of lymphoma and lower proportion of acute leukaemia in the intervention } \\
\text { group compared with the control group }\end{array}$ \\
\hline
\end{tabular}

Ruutu 2002

\begin{tabular}{|c|c|}
\hline Methods & $\begin{array}{l}\text { - Study design: parallel-group randomised controlled trial } \\
\text { - Stratification factor: stratified by risk of disease (low risk or high risk), type of donor (HLA-identical } \\
\text { sibling, other related donor, or unrelated donor), conditioning (with or without TBI), and centre (3 } \\
\text { centres) } \\
\text { - Settings: inpatients } \\
\text { - Study dates: January } 1996 \text { to November } 1998 \\
\text { - Location: Finland and Sweden }\end{array}$ \\
\hline Participants & $\begin{array}{l}\text { - Inclusion criteria: people undergoing allogeneic stem cell transplant } \\
\text { - Exclusion criteria: information not available } \\
\text { - Number of participants (intervention group : control group): } 124: 120 \\
\text { - Number of men (intervention group : control group): } 61: 61 \text { (gender in } 1 \text { participant in each group } \\
\text { unknown) } \\
\text { - Age of participants (intervention group : control group): median (range) in years: } 38(5-59): 40(1-58) \\
\text { (age in } 1 \text { participant in each group unknown) } \\
\text { - Underlying diseases: intervention group: ALL (26), AML (38), CML (31), CLL (2), MDS (11), NK cell } \\
\text { leukaemia (0), multiple myeloma (2), myelofibrosis (2), essential thrombocythaemia (0), hyper- } \\
\text { osinophilic syndrome (1), NHL (2), aplastic anaemia (3), Fanconi anaemia (1), amegakaryocytic throm- } \\
\text { bocytopenia (1), chronic granulomatous disease (1), familial haemophagocytic lymphohistiocytosis } \\
\text { (1), aspartylglucosaminuria (1), unknown (1); control group: ALL (24), AML (34), CML (37), CLL (2), MDS } \\
\text { (12), NK cell leukaemia (1), multiple myeloma (3), myelofibrosis (1), essential thrombocythaemia (1), } \\
\text { hypereosinophilic syndrome (0), NHL (2), aplastic anaemia (0), Fanconi anaemia (0), amegakaryocytic } \\
\text { thrombocytopenia (0), chronic granulomatous disease (1), familial haemophagocytic lymphohistio- } \\
\text { cytosis (1), aspartylglucosaminuria (0), unknown (1) } \\
\text { - Previous treatments (intervention group: control group): information not available } \\
\text { - Pre-existing liver dysfunction (intervention group : control group): information not available } \\
\text { - Previous history of hepatic VOD (intervention group : control group): information not available } \\
\text { - Performance status before transplant (intervention group: control group): information not available }\end{array}$ \\
\hline
\end{tabular}


Ruutu 2002 (Continued)

- Type of transplant: all participants received allogeneic transplant

- Donor: intervention group: matched sibling (64), other family member (2), unrelated (57), no transplant (1); control group: matched sibling (68), other family member (0), unrelated (51), no transplant (1)

- HLA disparity: (intervention group : control group): information not available

- Stem cell source: intervention group: bone marrow (97), peripheral blood stem cell (26), no transplant (1); control group: bone marrow (93), peripheral blood stem cell (26), no transplant (1)

- Stem cell manipulation (intervention group : control group): information not available

- Conditioning regimen: intervention group: cytostatic drugs only regimen (11), TBI containing regimen (112), no transplant (1); control group: cytostatic drugs only regimen (12), TBI containing regimen (107), no transplant (1)

- GVHD prophylaxis: intervention group: cyclosporin/methotrexate (63), cyclosporin/methylprednisolone (0), methotrexate/methylprednisolone (0), cyclosporin/methotrexate/methylprednisolone (57), cyclosporin/methotrexate/T-cell depletion (3), no transplant (1); control group: cyclosporin/methotrexate (60), cyclosporin/methylprednisolone (3), methotrexate/methylprednisolone (1), cyclosporin/methotrexate/methylprednisolone (55), cyclosporin/methotrexate/T-cell depletion (0), no transplant (1)

\begin{tabular}{ll} 
Interventions & Intervention group $(\mathrm{N}=124)$ : ursodeoxycholic acid $6 \mathrm{mg} / \mathrm{kg} / \mathrm{dose}$ twice daily orally from the day of \\
& conditioning till day 90 \\
- & Control group $(\mathrm{N}=120):$ placebo \\
\hline - Incidence of hepatic VOD \\
- Overall survival \\
- All-cause mortality at 100 days post-transplant \\
- Mortality attributable to hepatic VOD \\
- Frequency of adverse event (bleeding) \\
- Duration of follow-up: information not available \\
- Loss to follow-up (intervention group : control group): 1 (died before transplantation): 1 (cancellation \\
of transplantation) \\
- Funding source: information not available \\
- Declarations of interest: information not available
\end{tabular}

\section{Risk of bias}

\begin{tabular}{lll}
\hline Bias & Authors' judgement & Support for judgement \\
\hline $\begin{array}{l}\text { Random sequence genera- } \\
\text { tion (selection bias) }\end{array}$ & Unclear risk & Random sequence generation was not described \\
\hline $\begin{array}{l}\text { Allocation concealment } \\
\text { (selection bias) }\end{array}$ & Unclear risk & Allocation concealment was not described \\
\hline $\begin{array}{l}\text { Blinding of participants } \\
\begin{array}{l}\text { and personnel (perfor- } \\
\text { mance bias) }\end{array}\end{array}$ & High risk & Niether participants nor study personnel were blinded \\
All outcomes & \\
\hline
\end{tabular}

\begin{tabular}{lll}
$\begin{array}{l}\text { Blinding of outcome as- } \\
\text { sessment (detection bias) } \\
\text { All outcomes }\end{array}$ & Unclear risk & Blinding of outcome assessors was not described. \\
\hline $\begin{array}{l}\text { Incomplete outcome data } \\
\begin{array}{l}\text { (attrition bias) } \\
\text { All outcomes }\end{array}\end{array}$ & Low risk & $\begin{array}{l}\text { There was only } 1 \text { dropout in each group and unlikely to have significant influ- } \\
\text { ence on the overall outcome }\end{array}$ \\
\hline
\end{tabular}


Ruutu 2002 (Continued)

Selective reporting (re- Unclear risk $\quad$ Protocol was not available. It was unclear whether all pre-specified outcomes porting bias) were reported

Other bias Low risk No other bias was identified

Yannaki 2012

\begin{tabular}{|c|c|}
\hline Methods & $\begin{array}{l}\text { - Study design: parallel-group randomised controlled trial } \\
\text { - Stratification factor: none } \\
\text { - Settings: inpatients } \\
\text { - Study dates: not reported } \\
\text { - Location: Greece }\end{array}$ \\
\hline Participants & $\begin{array}{l}\text { - Inclusion criteria: people who underwent haematopoietic stem cell transplant } \\
\text { - Exclusion criteria: information not available } \\
\text { - Number of participants (intervention group : control group): } 172 \text { : } 164 \\
\text { - Number of men (intervention group : control group): information not available } \\
\text { - Age of participants (both groups): median (range) in years: } 36 \text { (5 - 68) } \\
\text { - Underlying diseases (intervention group : control group): information not available } \\
\text { - Previous treatments (intervention group : control group): information not available } \\
\text { - Pre-existing liver dysfunction (intervention group : control group): information not available } \\
\text { - Previous history of hepatic VOD (intervention group : control group): information not available } \\
\text { - Performance status before transplant (intervention group : control group): information not available } \\
\text { - Type of transplant (both groups): autologous (152), allogeneic (184) } \\
\text { - Donor (both groups): autologous (152), matched sibling (117), unrelated donor (61), others (6) } \\
\text { - HLA disparity (intervention group : control group): information not available } \\
\text { - Stem cell source (intervention group : control group): information not available } \\
\text { - Stem cell manipulation (intervention group : control group): information not available } \\
\text { - Conditioning regimen (both groups): busulfan (125), others (211) } \\
\text { - GVHD prophylaxis (intervention group : control group): information not available }\end{array}$ \\
\hline Interventions & $\begin{array}{l}\text { - Intervention group }(\mathrm{N}=172) \text { : fresh frozen plasma and heparin } \\
\text { - Control group }(\mathrm{N}=164) \text { : heparin alone }\end{array}$ \\
\hline Outcomes & - Incidence of hepatic VOD \\
\hline Notes & $\begin{array}{l}\text { - Duration of follow-up: } 100 \text { days } \\
\text { - Loss to follow-up (intervention group : control group): 0:0 } \\
\text { - Funding source: information not available } \\
\text { - Declarations of interest: information not available } \\
\text { - Information based on abstract only }\end{array}$ \\
\hline
\end{tabular}

\section{Risk of bias}

\begin{tabular}{lll}
\hline Bias & Authors' judgement & Support for judgement \\
\hline $\begin{array}{l}\text { Random sequence genera- } \\
\text { tion (selection bias) }\end{array}$ & Unclear risk & Random sequence generation was not described \\
\hline $\begin{array}{l}\text { Allocation concealment } \\
\text { (selection bias) }\end{array}$ & Unclear risk & Allocation concealment was not described \\
\hline
\end{tabular}


Yannaki 2012 (Continued)

Blinding of participants High risk Neither participants nor study personnel were blinded and personnel (perfor-

mance bias)

All outcomes

\begin{tabular}{lll}
\hline $\begin{array}{l}\text { Blinding of outcome as- } \\
\text { sessment (detection bias) } \\
\text { All outcomes }\end{array}$ & Unclear risk & Blinding of outcome assessors was not described \\
\hline $\begin{array}{l}\text { Incomplete outcome data } \\
\text { (attrition bias) } \\
\text { All outcomes }\end{array}$ & Low risk & There was no dropout \\
\hline $\begin{array}{l}\text { Selective reporting (re- } \\
\text { porting bias) }\end{array}$ & Unclear risk & $\begin{array}{l}\text { Protocol was not available. It was unclear whether all pre-specified outcomes } \\
\text { were reported }\end{array}$ \\
\hline $\begin{array}{l}\text { Other bias } \\
\text { Unclear risk }\end{array}$ & $\begin{array}{l}\text { We were not certain whether important baseline characteristics of the partici- } \\
\text { pants in different treatment groups were comparable or not. We were also not } \\
\text { certain whether different treatment groups received same co-interventions }\end{array}$ \\
\hline
\end{tabular}

ALL: acute lymphoblastic leukaemia; AML: acute myeloid leukaemia; AST: aspartate aminotransferase; ATG: anti-thymocyte globulin; BEAM: carmustine, etoposide, cytarabine, melphalan; BMT: bone marrow transplantation; BU: busulfan; CBV: cyclophosphamide, carmustine, etoposide; CLL: chronic lymphocytic leukaemia; CML: chronic myeloid leukaemia; CTEM: cyclophosphamide, thiotepa, etoposide, melphalan; CY: cyclophosphamide; EBV: Ebstein-Barr virus; ECYM: etoposide, cyclophosphamide, melphalan; GVHD: graftversus-host disease; HLA: human leukocyte antigen; MDS: myelodysplastic syndrome; MEL: melphalan; NHL: non-Hodgkin lymphoma; NK: natural killer; PGE1: prostaglandin E1; SD: standard deviation; T: thiotepa; TBI: total body irradiation; TECAM: thiotepa, etoposide, cyclophosphamide, cytarabine, melphalan; TLI: total lymphoid irradiation; VOD: veno-occlusive disease

Characteristics of excluded studies [ordered by study ID]

Study Reason for exclusion

Carbacioglu 2004

Trial on treatment of hepatic veno-occlusive disease and not prophylaxis

Characteristics of ongoing studies [ordered by study ID]

JPRN-UMIN000013455

Trial name or title Efficacy and safety study of defibrotide (DF) for the prophylaxis of veno-occlusive disease (VOD)

Methods Parallel-group randomised controlled trial

Participants

\section{Inclusion criteria:}

1. 0 - 50 years old (at informed consent)

2. Primary disease is one of the following:

-malignant tumour not in remission

-malignant tumour in remission.

-osteopetrosis

-non-malignant disease other than osteopetrosis

3. People with 1 or more following risk factors of hepatic VOD who undergo allogeneic stem cell transplantation with myeloablative conditioning regimen:

-Second myeloablative transplant

-Not in remission at transplant

-Performance status (ECOG) of 2 or more 
-Conditioning regimen including BU-MEL or BU-CY

-Liver dysfunction before stem cell transplant

-Positive for anti-HCV antibody

-Administration of gemtuzumab ozogamicin within 100 days before stem cell transplant

-Osteopetrosis

4. Witten informed consent to participate in the study from the participant or legally acceptable representative before screening tests

\section{Exclusion criteria:}

1. Using medication that increases risk of haemorrhage

2. Acute bleeding that is not controlled

3. Unstable haemodynamic status that require more than 1 vasopressor or decreased mean atrial pressure (MAP)

4. Complicated with viral fulminant hepatitis

5. Past history of organ transplant other than hematopoietic cell transplant

6. Complicated with grade IV GVHD

7. Women with pregnancy, breastfeeding, possible pregnancy. Men who will not consent to contraception

8. Judged as inappropriate for participating in the study by the principal or other investigator for other reasons

Interventions

Outcomes
- Intervention group: intravenous infusion of defibrotide $6.25 \mathrm{mg} / \mathrm{kg} / \mathrm{dose}$ over 2 hours every 6 hours, from 1 day before starting conditioning regimen until day 30 post-transplant (for a maximum of 100 days after transplantation)

- Control group: standard treatment only
Starting date

\section{Primary outcome:}

Incidence of hepatic VOD until day 30 post-transplant

Principal or other investigator should evaluate the development of hepatic VOD according to the revised Seattle criteria. Hepatic VOD is defined as those who meet at least 2 of the following criteria by day 35 post stem cell transplant:

-Total Bilirubin $\geq 2 \mathrm{mg} / \mathrm{dL}$

-Hepatomegaly

-Right hypochondriac pain

-Ascites

-Unexplained weight gain of more than $5 \%$ from baseline

\section{Secondary outcomes:}

1) Incidence of hepatic VOD at day 100 post-transplant

2) Incidence of hepatic VOD according to the Baltimore criteria at day 30 and day 100 post-transplant

3) Severity of hepatic VOD in people who developed VOD

4) Incidence of total, grade II-IV, and III-IV acute GVHD at day 100 post-transplant

5) Survival at day 100 and day 180 post-transplant

6) Survival at day 100 and day 180 post-transplant in people who developed hepatic VOD

7) Incidence and severity of adverse events and drug-related adverse event

8) Date of engraftment

9) Remission status of the original disease at day 30, 100, and 180 after stem cell transplant in people with malignancy
7 March 2014

- Name: Miwa Izutsu

- Address: 3-3-2Tsukiji, Chuo-ku, Tokyo, 140-0045, Japan

- Telephone: 03-6228-4835

- Email: chosei@fmu-df.jp 


\begin{tabular}{|c|c|}
\hline Trial name or title & $\begin{array}{l}\text { A randomised control study on the effects of glutamine on the clinical outcome of bone marrow } \\
\text { transplant recipients with special reference to veno-occlusive disease and mucositis }\end{array}$ \\
\hline Methods & Parallel-group randomised controlled trial \\
\hline \multirow[t]{3}{*}{ Participants } & Inclusion Criteria: \\
\hline & Aged above 18 years \\
\hline & $\begin{array}{l}\text { Allogeneic bone marrow transplant recipients using busulfan and cyclophosphamide as condition- } \\
\text { ing }\end{array}$ \\
\hline Interventions & $\begin{array}{l}\text { - Intervention group: glutamine added to parenteral nutrition } \\
\text { - Control group: standard parenteral nutrition }\end{array}$ \\
\hline \multirow[t]{6}{*}{ Outcomes } & Primary outcomes: \\
\hline & Mucositis at 1 month \\
\hline & Veno-occlusive disease at 1 month \\
\hline & Secondary outcomes: \\
\hline & Hospital stay (up to 2 months) \\
\hline & Use of antibiotics (up to 2 months) \\
\hline Starting date & July 2004 \\
\hline Contact information & $\begin{array}{l}\text { - Name: Dr YH Leung } \\
\text { - Address: Department of Medicine/Division of Haematology, Queen Mary Hospital, Hong Kong } \\
\text { - Telephone: (852) } 28553347 \\
\text { - Email: ayhleung@hku.hk }\end{array}$ \\
\hline
\end{tabular}

BU: busulfan; CY: cyclophosphamide; ECOG: Eastern Cooperative Oncology Group; GVHD: graft-versus-host disease; HCV: hepatitis C virus; MEL: melphalan

\section{DATA AND ANALYSES}

Comparison 1. Ursodeoxycholic acid versus placebo or no treatment

\begin{tabular}{lllll}
\hline Outcome or subgroup title & $\begin{array}{l}\text { No. of } \\
\text { studies }\end{array}$ & $\begin{array}{l}\text { No. of } \\
\text { partici- } \\
\text { pants }\end{array}$ & Statistical method & Effect size \\
\hline 1 Incidence of hepatic VOD & 4 & 612 & Risk Ratio (M-H, Fixed, 95\% Cl) & $0.60[0.40,0.88]$ \\
\hline
\end{tabular}




\begin{tabular}{lllll}
\hline Outcome or subgroup title & $\begin{array}{l}\text { No. of } \\
\text { studies }\end{array}$ & $\begin{array}{l}\text { No. of } \\
\text { partici- } \\
\text { pants }\end{array}$ & Statistical method & Effect size \\
\hline 2 Overall survival & 3 & 474 & Hazard Ratio $(95 \% \mathrm{Cl})$ & $0.83[0.59,1.18]$ \\
\hline $\begin{array}{l}\text { 3 All-cause mortality at 100 days } \\
\text { post-transplant }\end{array}$ & 4 & 612 & Risk Ratio (M-H, Fixed, 95\% Cl) & $0.70[0.50,0.99]$ \\
\hline $\begin{array}{l}4 \text { Mortality attributable to hepat- } \\
\text { ic VOD }\end{array}$ & 4 & 612 & Risk Ratio (M-H, Fixed, 95\% Cl) & $0.27[0.09,0.87]$ \\
\hline \begin{tabular}{l}
5 Frequency of adverse events \\
\hline
\end{tabular} & 1 & & Risk Ratio (M-H, Fixed, 95\% Cl) & Totals not selected \\
\hline
\end{tabular}

\section{Analysis 1.1. Comparison 1 Ursodeoxycholic acid versus placebo or no treatment, Outcome 1 Incidence of hepatic VOD.}

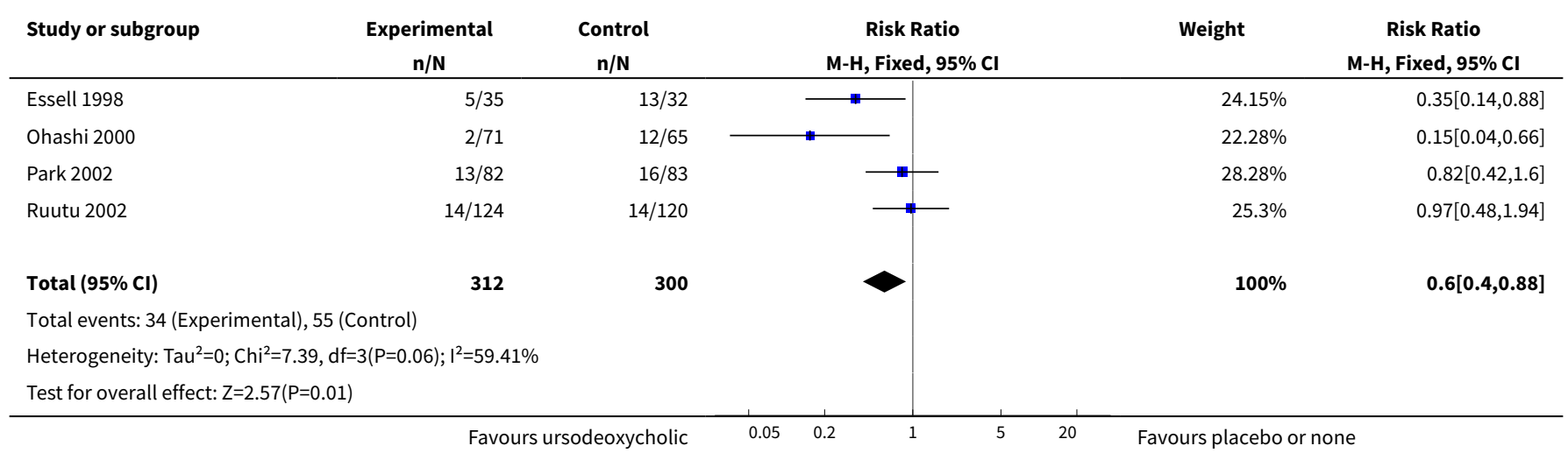

\section{Analysis 1.2. Comparison 1 Ursodeoxycholic acid versus placebo or no treatment, Outcome 2 Overall survival.}

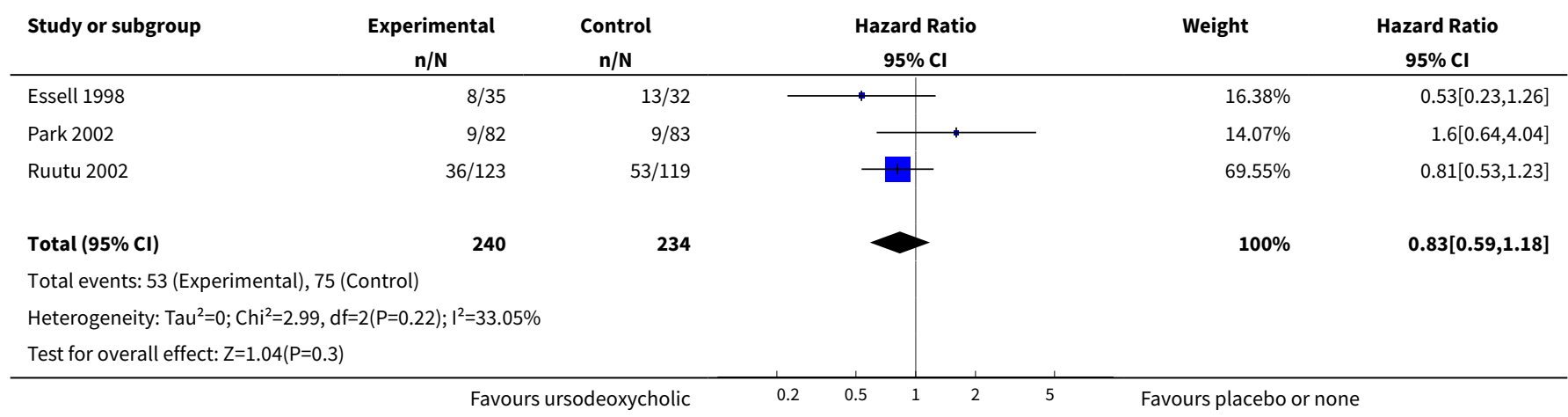


Analysis 1.3. Comparison 1 Ursodeoxycholic acid versus placebo or no treatment, Outcome 3 All-cause mortality at 100 days post-transplant.

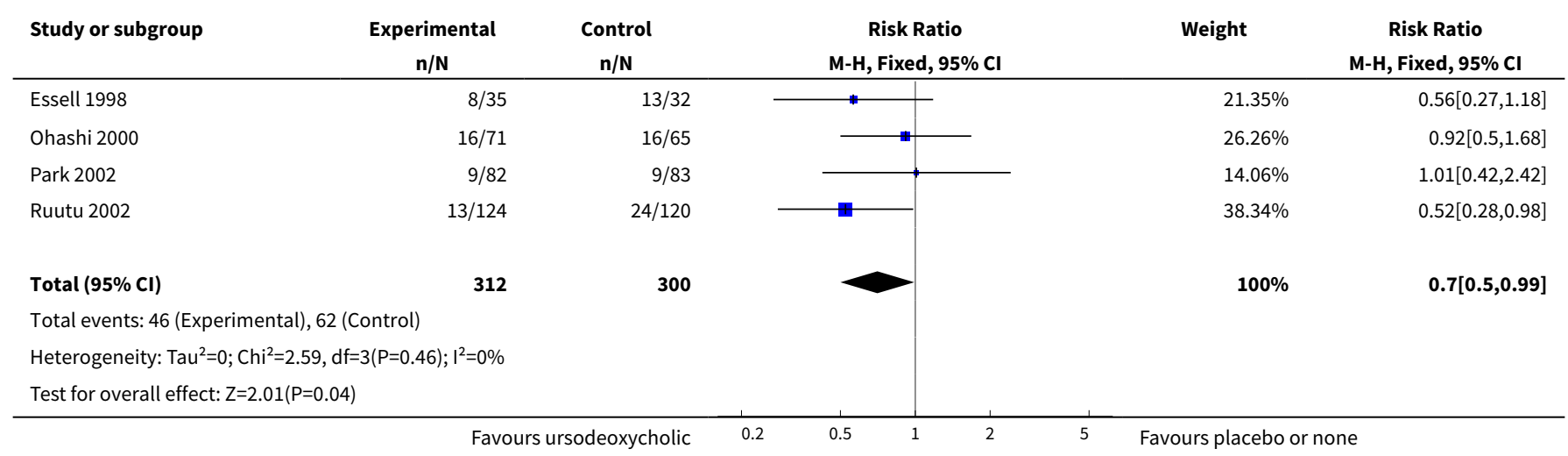

Analysis 1.4. Comparison 1 Ursodeoxycholic acid versus placebo or no treatment, Outcome 4 Mortality attributable to hepatic VOD.

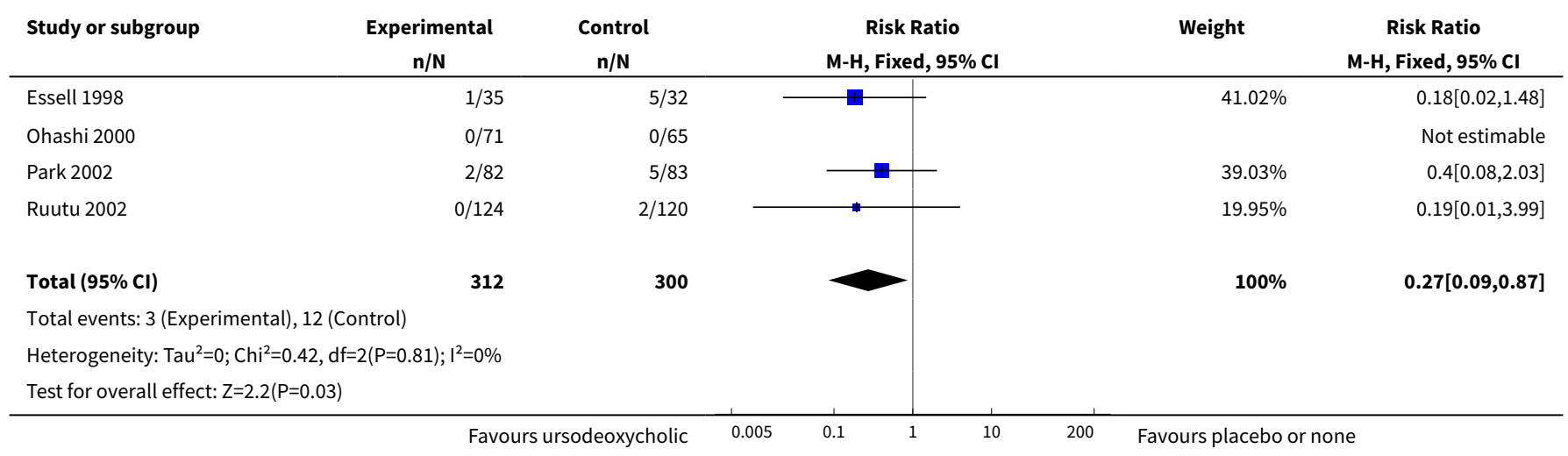

Analysis 1.5. Comparison 1 Ursodeoxycholic acid versus placebo or no treatment, Outcome 5 Frequency of adverse events.

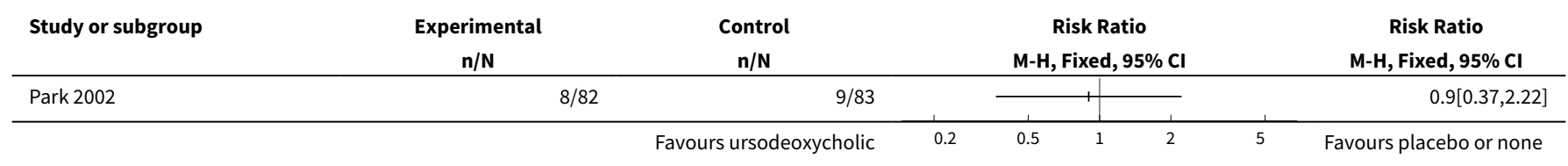

\section{Comparison 2. Heparin versus no treatment}

\begin{tabular}{lllll}
\hline Outcome or subgroup title & $\begin{array}{l}\text { No. of } \\
\text { studies }\end{array}$ & $\begin{array}{l}\text { No. of } \\
\text { partici- } \\
\text { pants }\end{array}$ & Statistical method & Effect size \\
\hline 1 Incidence of hepatic VOD & 2 & 259 & Risk Ratio (M-H, Fixed, 95\% Cl) & $0.47[0.18,1.26]$ \\
\hline
\end{tabular}




\begin{tabular}{|c|c|c|c|c|}
\hline Outcome or subgroup title & $\begin{array}{l}\text { No. of } \\
\text { studies }\end{array}$ & $\begin{array}{l}\text { No. of } \\
\text { partici- } \\
\text { pants }\end{array}$ & Statistical method & Effect size \\
\hline 2 Overall survival & & & Other data & No numeric data \\
\hline $\begin{array}{l}3 \text { All-cause mortality at } 100 \text { days } \\
\text { post-transplant }\end{array}$ & 1 & & Risk Ratio (M-H, Fixed, 95\% Cl) & Totals not selected \\
\hline $\begin{array}{l}4 \text { Mortality attributable to hepat- } \\
\text { ic VOD }\end{array}$ & 1 & & Risk Ratio (M-H, Fixed, 95\% Cl) & Totals not selected \\
\hline 5 Frequency of adverse events & 1 & & Risk Ratio (M-H, Fixed, 95\% Cl) & Totals not selected \\
\hline
\end{tabular}

Analysis 2.1. Comparison 2 Heparin versus no treatment, Outcome 1 Incidence of hepatic VOD.

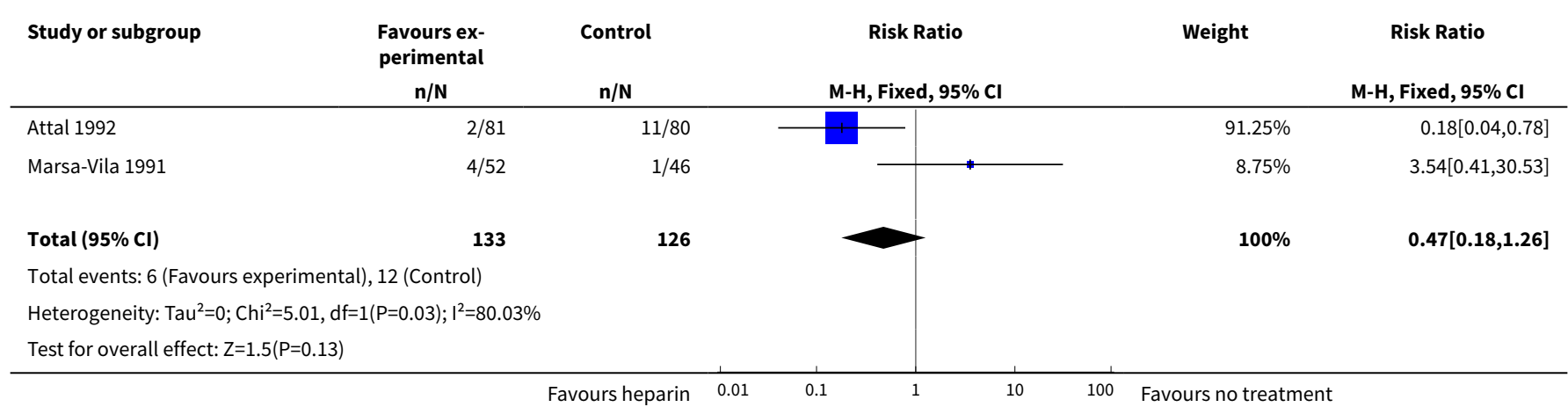

Analysis 2.2. Comparison 2 Heparin versus no treatment, Outcome 2 Overall survival.

\begin{tabular}{lccc} 
& & $\begin{array}{c}\text { Overall survival } \\
\text { Heparin group }\end{array}$ & No treatment group \\
\hline Attal 1992 & $92.6 \%$ & & $88.7 \%$ \\
\hline
\end{tabular}

Analysis 2.3. Comparison 2 Heparin versus no treatment, Outcome 3 All-cause mortality at 100 days post-transplant.

\begin{tabular}{|c|c|c|c|c|c|c|}
\hline \multirow{2}{*}{$\begin{array}{l}\text { Study or subgroup } \\
\text { Attal } 1992\end{array}$} & $\begin{array}{c}\text { Experimental } \\
n / N \\
\end{array}$ & $\begin{array}{c}\text { Control } \\
\mathrm{n} / \mathrm{N}\end{array}$ & \multicolumn{3}{|c|}{$\begin{array}{c}\text { Risk Ratio } \\
\text { M-H, Fixed, 95\% Cl }\end{array}$} & \multirow{2}{*}{$\begin{array}{c}\text { Risk Ratio } \\
\text { M-H, Fixed, 95\% Cl } \\
0.66[0.25,1.76]\end{array}$} \\
\hline & $6 / 81$ & $9 / 80$ & & 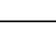 & 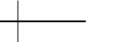 & \\
\hline
\end{tabular}


Analysis 2.4. Comparison 2 Heparin versus no treatment, Outcome 4 Mortality attributable to hepatic VOD.

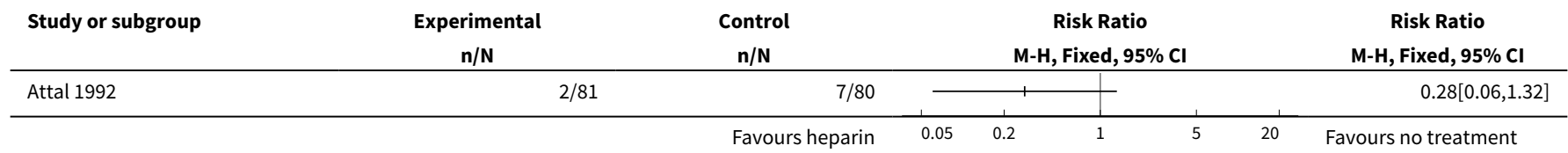

Analysis 2.5. Comparison 2 Heparin versus no treatment, Outcome 5 Frequency of adverse events.

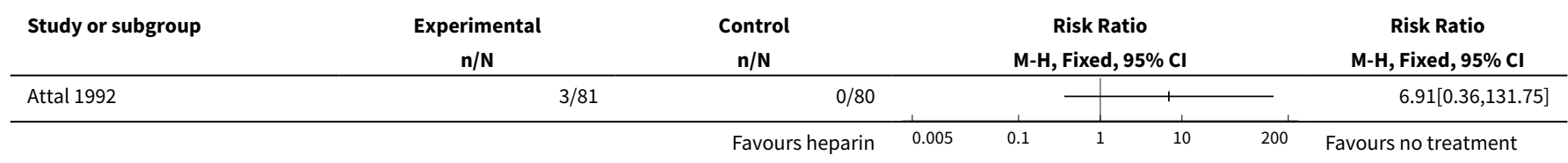

Comparison 3. Low molecular weight heparin versus placebo or no treatment

\begin{tabular}{lllll}
\hline Outcome or subgroup title & $\begin{array}{l}\text { No. of } \\
\text { studies }\end{array}$ & $\begin{array}{l}\text { No. of } \\
\text { partici- } \\
\text { pants }\end{array}$ & Statistical method & Effect size \\
\hline 1 Incidence of hepatic VOD & 1 & & Risk Ratio (M-H, Fixed, 95\% Cl) & Totals not selected \\
\hline 2 Frequency of adverse events & 1 & Risk Ratio (M-H, Fixed, 95\% Cl) & Totals not selected \\
\hline
\end{tabular}

Analysis 3.1. Comparison 3 Low molecular weight heparin versus placebo or no treatment, Outcome 1 Incidence of hepatic VOD.

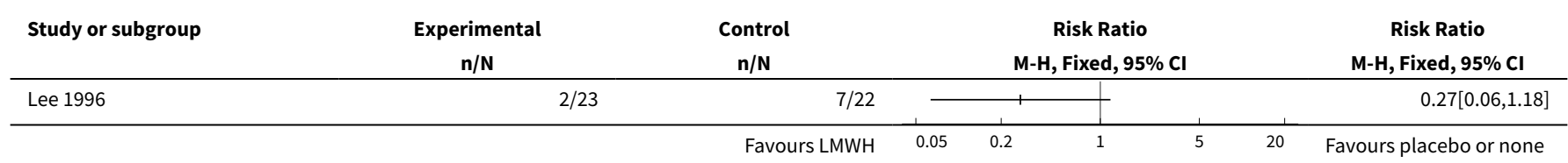

Analysis 3.2. Comparison 3 Low molecular weight heparin versus placebo or no treatment, Outcome 2 Frequency of adverse events.

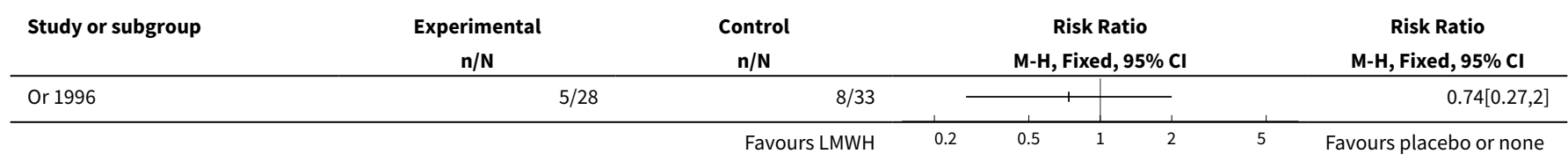


Comparison 4. Defibrotide versus no treatment

\begin{tabular}{|c|c|c|c|c|}
\hline Outcome or subgroup title & $\begin{array}{l}\text { No. of } \\
\text { studies }\end{array}$ & $\begin{array}{l}\text { No. of } \\
\text { partici- } \\
\text { pants }\end{array}$ & Statistical method & Effect size \\
\hline 1 Incidence of hepatic VOD & 1 & & Risk Ratio (M-H, Fixed, 95\% Cl) & Totals not selected \\
\hline $\begin{array}{l}2 \text { Subgroup analyses of inci- } \\
\text { dence of hepatic VOD by age } \\
\text { groups }\end{array}$ & 1 & & Risk Ratio (M-H, Fixed, 95\% Cl) & Totals not selected \\
\hline 2.1 Infants and children & 1 & & Risk Ratio (M-H, Fixed, 95\% Cl) & $0.0[0.0,0.0]$ \\
\hline 2.2 Adolescents & 1 & & Risk Ratio (M-H, Fixed, 95\% Cl) & $0.0[0.0,0.0]$ \\
\hline $\begin{array}{l}3 \text { Subgroup analysis for inci- } \\
\text { dence of hepatic VOD by un- } \\
\text { derlying diseases }\end{array}$ & 1 & & Risk Ratio (M-H, Fixed, 95\% Cl) & Totals not selected \\
\hline 3.1 Osteopetrosis & 1 & & Risk Ratio (M-H, Fixed, 95\% Cl) & $0.0[0.0,0.0]$ \\
\hline $\begin{array}{l}3.2 \text { Diseases other than os- } \\
\text { teopetrosis }\end{array}$ & 1 & & Risk Ratio (M-H, Fixed, 95\% Cl) & $0.0[0.0,0.0]$ \\
\hline $\begin{array}{l}4 \text { Subgroup analysis of inci- } \\
\text { dence of hepatic VOD by type } \\
\text { of transplant }\end{array}$ & 1 & & Risk Ratio (M-H, Fixed, 95\% Cl) & Totals not selected \\
\hline 4.1 Allogeneic & 1 & & Risk Ratio (M-H, Fixed, 95\% Cl) & $0.0[0.0,0.0]$ \\
\hline 4.2 Autologous & 1 & & Risk Ratio (M-H, Fixed, 95\% Cl) & $0.0[0.0,0.0]$ \\
\hline 5 Overall survival & 1 & & Hazard Ratio (95\% Cl) & Totals not selected \\
\hline $\begin{array}{l}6 \text { All-cause mortality at } 100 \\
\text { days post-transplant }\end{array}$ & 1 & & Risk Ratio (M-H, Fixed, 95\% Cl) & Totals not selected \\
\hline $\begin{array}{l}7 \text { Mortality attributable to he- } \\
\text { patic VOD }\end{array}$ & 1 & & Risk Ratio (M-H, Fixed, 95\% Cl) & Totals not selected \\
\hline $\begin{array}{l}8 \text { Frequency of adverse } \\
\text { events }\end{array}$ & 1 & & Risk Ratio (M-H, Fixed, 95\% Cl) & Totals not selected \\
\hline $\begin{array}{l}9 \text { Frequency of severe ad- } \\
\text { verse events }\end{array}$ & 1 & & Risk Ratio (M-H, Fixed, 95\% Cl) & Totals not selected \\
\hline $\begin{array}{l}10 \text { Frequency of haemor- } \\
\text { rhage }\end{array}$ & 1 & & Risk Ratio (M-H, Fixed, 95\% Cl) & Totals not selected \\
\hline
\end{tabular}


Analysis 4.1. Comparison 4 Defibrotide versus no treatment, Outcome 1 Incidence of hepatic VOD.

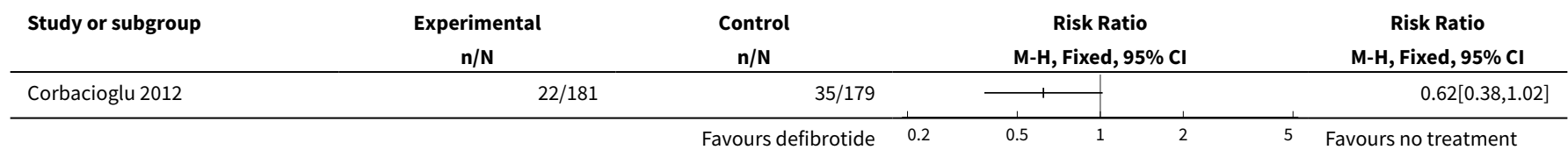

Analysis 4.2. Comparison 4 Defibrotide versus no treatment, Outcome 2 Subgroup analyses of incidence of hepatic VOD by age groups.

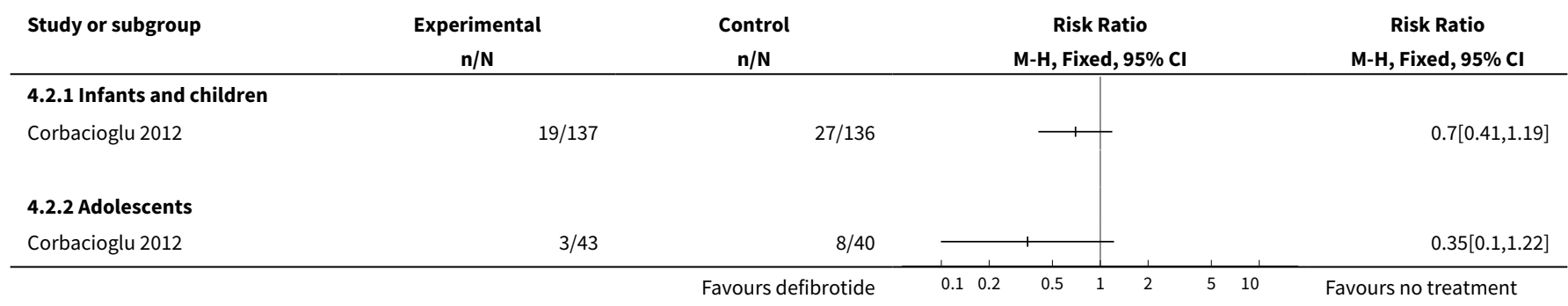

Analysis 4.3. Comparison 4 Defibrotide versus no treatment, Outcome 3

Subgroup analysis for incidence of hepatic VOD by underlying diseases.

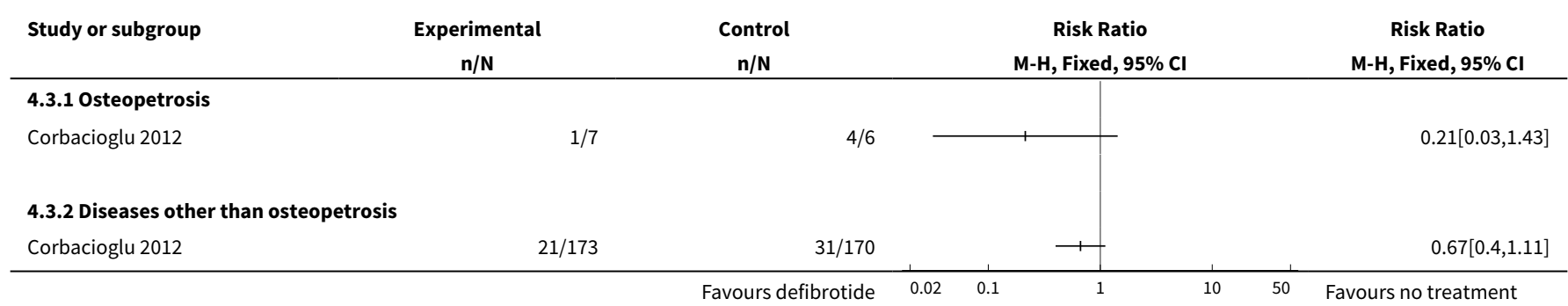

Analysis 4.4. Comparison 4 Defibrotide versus no treatment, Outcome 4 Subgroup analysis of incidence of hepatic VOD by type of transplant.

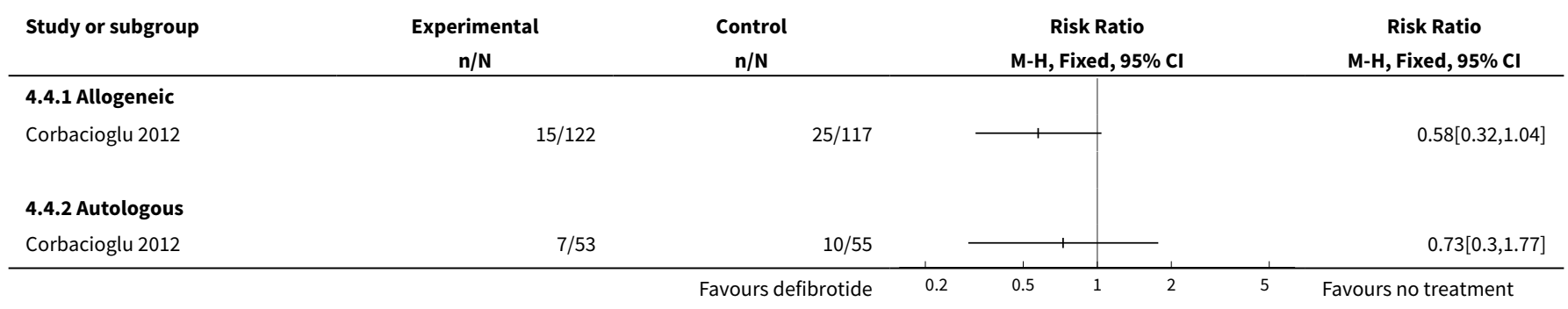


Analysis 4.5. Comparison 4 Defibrotide versus no treatment, Outcome 5 Overall survival.

\begin{tabular}{|c|c|c|c|c|}
\hline Study or subgroup & $\begin{array}{c}\text { Experimental } \\
n / N\end{array}$ & $\begin{array}{c}\text { Control } \\
n / N\end{array}$ & $\begin{array}{c}\text { Hazard Ratio } \\
95 \% \mathrm{Cl}\end{array}$ & $\begin{array}{c}\text { Hazard Ratio } \\
95 \% \mathrm{Cl}\end{array}$ \\
\hline Corbacioglu 2012 & $18 / 180$ & $17 / 176$ & - & $1.04[0.54,2.02]$ \\
\hline
\end{tabular}

Analysis 4.6. Comparison 4 Defibrotide versus no treatment, Outcome 6 All-cause mortality at 100 days post-transplant.

\begin{tabular}{|c|c|c|c|c|}
\hline Study or subgroup & $\begin{array}{c}\text { Experimental } \\
n / N\end{array}$ & $\begin{array}{c}\text { Control } \\
n / N\end{array}$ & $\begin{array}{c}\text { Risk Ratio } \\
\text { M-H, Fixed, 95\% Cl }\end{array}$ & $\begin{array}{c}\text { Risk Ratio } \\
\text { M-H, Fixed, } 95 \% \mathrm{CI}\end{array}$ \\
\hline Corbacioglu 2012 & $18 / 181$ & $17 / 179$ & 1 & $1.05[0.56,1.97]$ \\
\hline
\end{tabular}

Analysis 4.7. Comparison 4 Defibrotide versus no treatment, Outcome 7 Mortality attributable to hepatic VOD.

\begin{tabular}{|c|c|c|c|c|c|c|c|}
\hline \multirow{2}{*}{$\begin{array}{l}\text { Study or subgroup } \\
\text { Corbacioglu } 2012\end{array}$} & $\begin{array}{l}\text { Experimental } \\
n / N\end{array}$ & $\begin{array}{c}\text { Control } \\
n / N\end{array}$ & \multicolumn{4}{|c|}{$\begin{array}{c}\text { Risk Ratio } \\
\text { M-H, Fixed, 95\% Cl }\end{array}$} & \multirow{2}{*}{$\begin{array}{c}\text { Risk Ratio } \\
\text { M-H, Fixed, 95\% Cl } \\
0.4[0.13,1.24\end{array}$} \\
\hline & $4 / 181$ & $10 / 179$ & & & + & + & \\
\hline
\end{tabular}

Analysis 4.8. Comparison 4 Defibrotide versus no treatment, Outcome 8 Frequency of adverse events.

\begin{tabular}{|c|c|c|c|c|c|c|}
\hline \multirow{2}{*}{$\begin{array}{l}\text { Study or subgroup } \\
\text { Corbacioglu } 2012\end{array}$} & $\begin{array}{c}\text { Experimental } \\
n / N \\
\end{array}$ & $\begin{array}{c}\text { Control } \\
\mathrm{n} / \mathrm{N}\end{array}$ & \multicolumn{3}{|c|}{$\begin{array}{c}\text { Risk Ratio } \\
\text { M-H, Fixed, 95\% Cl }\end{array}$} & \multirow{2}{*}{$\begin{array}{c}\text { Risk Ratio } \\
\begin{array}{c}\text { M-H, Fixed, 95\% Cl } \\
18.79[1.1,320.45\end{array}\end{array}$} \\
\hline & $9 / 181$ & $0 / 179$ & & & $\longrightarrow$ & \\
\hline
\end{tabular}

Analysis 4.9. Comparison 4 Defibrotide versus no treatment, Outcome 9 Frequency of severe adverse events.

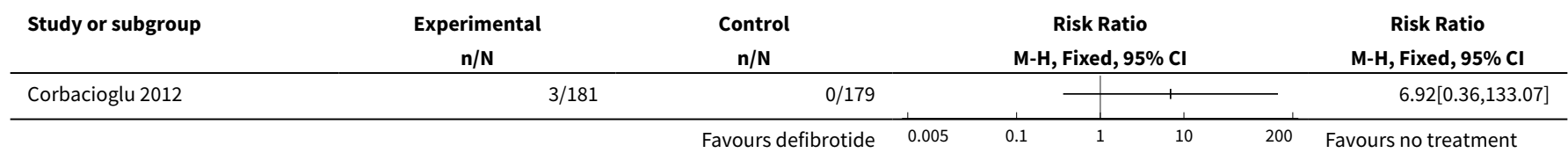

Analysis 4.10. Comparison 4 Defibrotide versus no treatment, Outcome 10 Frequency of haemorrhage.

\begin{tabular}{|c|c|c|c|c|c|c|}
\hline Study or subgroup & $\begin{array}{c}\text { Experimental } \\
n / N\end{array}$ & $\begin{array}{c}\text { Control } \\
\mathrm{n} / \mathrm{N}\end{array}$ & & & $\begin{array}{l}\text { Ratio } \\
\text { ed, } 95 \% \mathrm{Cl}\end{array}$ & $\begin{array}{c}\text { Risk Ratio } \\
\text { M-H, Fixed, } 95 \% \text { CI }\end{array}$ \\
\hline Corbacioglu 2012 & $39 / 181$ & $37 / 179$ & & & + & $1.04[0.7,1.55]$ \\
\hline
\end{tabular}


Comparison 5. Glutamine versus placebo

\begin{tabular}{lllll}
\hline Outcome or subgroup title & $\begin{array}{l}\text { No. of } \\
\text { studies }\end{array}$ & $\begin{array}{l}\text { No. of } \\
\text { partici- } \\
\text { pants }\end{array}$ & Statistical method & Effect size \\
\hline $\begin{array}{l}1 \text { All-cause mortality at } 100 \text { days post- } \\
\text { transplant }\end{array}$ & 1 & Risk Ratio (M-H, Fixed, 95\% Cl) & Totals not selected \\
\hline 2 Frequency of adverse events & 1 & Risk Ratio (M-H, Fixed, 95\% Cl) & Totals not selected \\
\hline
\end{tabular}

Analysis 5.1. Comparison 5 Glutamine versus placebo, Outcome 1 All-cause mortality at 100 days post-transplant.

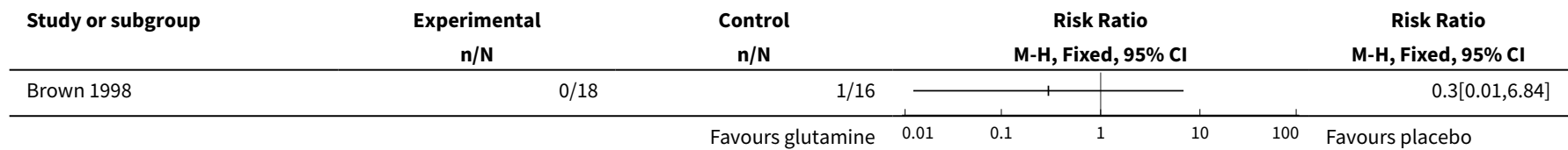

Analysis 5.2. Comparison 5 Glutamine versus placebo, Outcome 2 Frequency of adverse events.

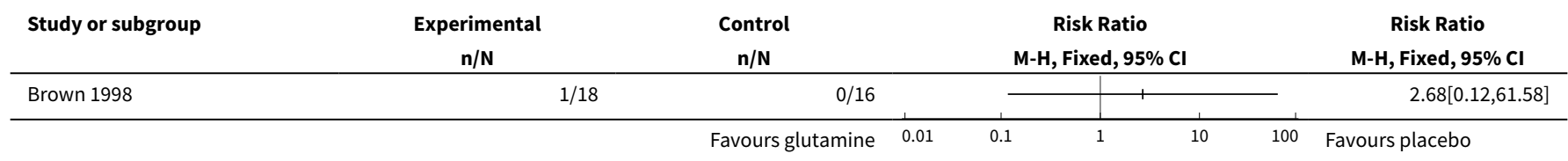

Comparison 6. Fresh frozen plasma versus no treatment

\begin{tabular}{lllll}
\hline Outcome or subgroup title & $\begin{array}{l}\text { No. of } \\
\text { studies }\end{array}$ & $\begin{array}{l}\text { No. of partici- } \\
\text { pants }\end{array}$ & Statistical method & Effect size \\
\hline 1 Incidence of hepatic VOD & 2 & 383 & Risk Ratio (M-H, Fixed, 95\% Cl) & $0.66[0.20,2.17]$ \\
\hline
\end{tabular}

Analysis 6.1. Comparison 6 Fresh frozen plasma versus no treatment, Outcome 1 Incidence of hepatic VOD.

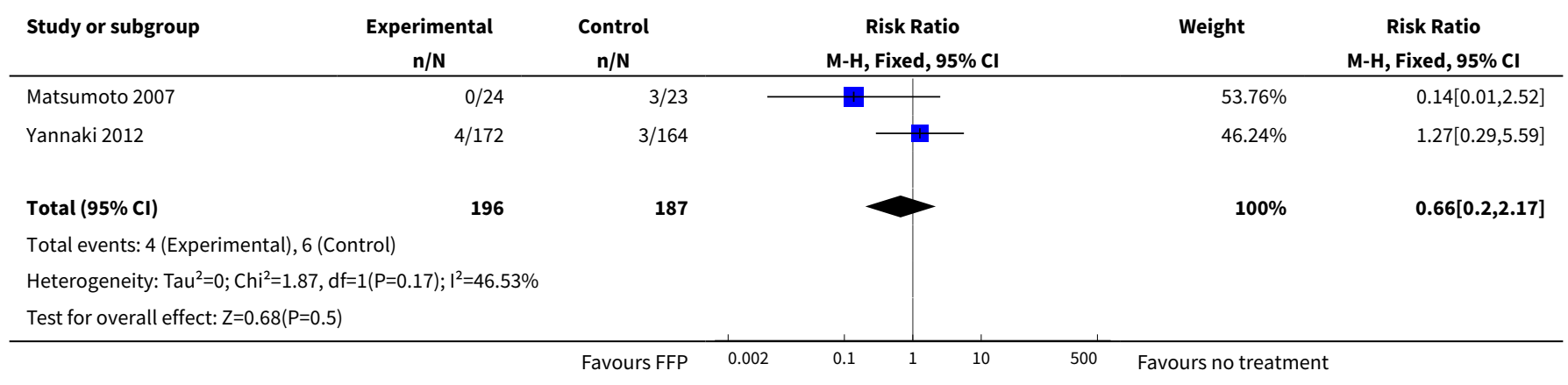


Comparison 7. Antithrombin III plus heparin versus heparin alone

\begin{tabular}{lllll}
\hline Outcome or subgroup title & $\begin{array}{l}\text { No. of } \\
\text { studies }\end{array}$ & $\begin{array}{l}\text { No. of } \\
\text { partici- } \\
\text { pants }\end{array}$ & Statistical method & Effect size \\
\hline 1 Incidence of hepatic VOD & 1 & & Risk Ratio (M-H, Fixed, 95\% Cl) & Totals not selected \\
\hline 2 Frequency of adverse events & 1 & Risk Ratio (M-H, Fixed, 95\% Cl) & Totals not selected \\
\hline
\end{tabular}

Analysis 7.1. Comparison 7 Antithrombin III plus heparin versus heparin alone, Outcome 1 Incidence of hepatic VOD.

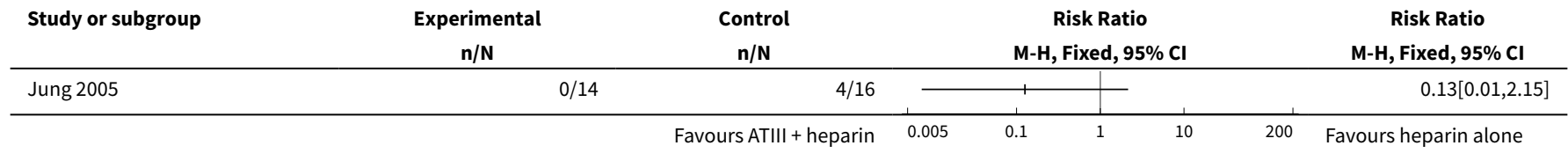

Analysis 7.2. Comparison 7 Antithrombin III plus heparin versus heparin alone, Outcome 2 Frequency of adverse events.

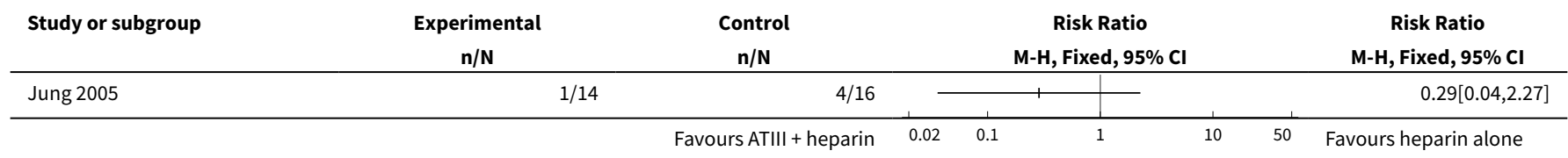

\section{Comparison 8. Heparin versus low molecular weight heparin}

\begin{tabular}{lllll}
\hline Outcome or subgroup title & $\begin{array}{l}\text { No. of } \\
\text { studies }\end{array}$ & $\begin{array}{l}\text { No. of } \\
\text { partici- } \\
\text { pants }\end{array}$ & Statistical method & Effect size \\
\hline 1 Incidence of hepatic VOD & 1 & Risk Ratio (M-H, Fixed, 95\% Cl) & Totals not selected \\
\hline $\begin{array}{l}\text { 2 Mortality attributable to hepat- } \\
\text { ic VOD }\end{array}$ & 1 & Risk Ratio (M-H, Fixed, 95\% Cl) & Totals not selected \\
\hline 3 Frequency of adverse events & 1 & Risk Ratio (M-H, Fixed, $95 \% \mathrm{Cl})$ & Totals not selected \\
\hline
\end{tabular}


Analysis 8.1. Comparison 8 Heparin versus low molecular weight heparin, Outcome 1 Incidence of hepatic VOD.

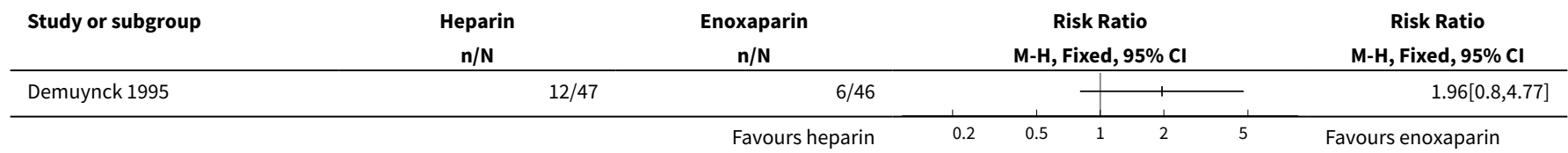

Analysis 8.2. Comparison 8 Heparin versus low molecular weight heparin, Outcome 2 Mortality attributable to hepatic VOD.

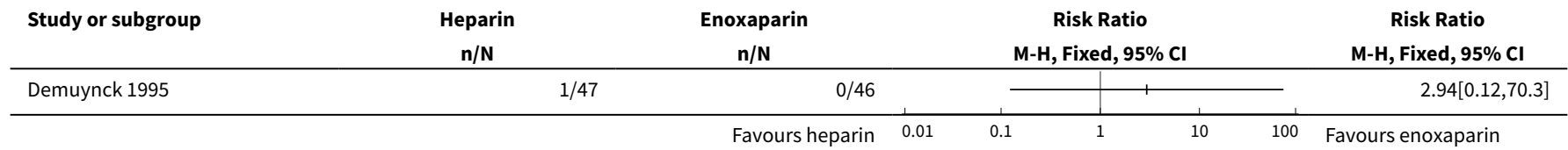

Analysis 8.3. Comparison 8 Heparin versus low molecular weight heparin, Outcome 3 Frequency of adverse events.

\begin{tabular}{|c|c|c|c|c|c|c|}
\hline \multirow{2}{*}{$\begin{array}{l}\text { Study or subgroup } \\
\text { Demuynck } 1995\end{array}$} & $\begin{array}{c}\text { Heparin } \\
\mathrm{n} / \mathrm{N}\end{array}$ & $\begin{array}{c}\text { Enoxaparin } \\
n / N \\
\end{array}$ & \multicolumn{3}{|c|}{$\begin{array}{c}\text { Risk Ratio } \\
\text { M-H, Fixed, 95\% CI }\end{array}$} & \multirow{2}{*}{$\begin{array}{c}\text { Risk Ratio } \\
\text { M-H, Fixed, 95\% Cl } \\
0.84[0.3,2.31]\end{array}$} \\
\hline & $6 / 47$ & $7 / 46$ & & 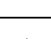 & 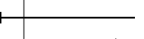 & \\
\hline
\end{tabular}

Comparison 9. Heparin versus prostaglandin E1

\begin{tabular}{lllll}
\hline Outcome or subgroup title & $\begin{array}{l}\text { No. of } \\
\text { studies }\end{array}$ & $\begin{array}{l}\text { No. of } \\
\text { partici- } \\
\text { pants }\end{array}$ & Statistical method & Effect size \\
\hline 1 Incidence of hepatic VOD & 1 & Risk Ratio (M-H, Fixed, 95\% Cl) & Totals not selected \\
\hline $\begin{array}{l}2 \text { Mortality attributable to hepat- } \\
\text { ic VOD }\end{array}$ & 1 & Risk Ratio (M-H, Fixed, 95\% Cl) & Totals not selected \\
\hline 3 Frequency of adverse events & 1 & Risk Ratio (M-H, Fixed, $95 \% \mathrm{Cl})$ & Totals not selected \\
\hline
\end{tabular}

Analysis 9.1. Comparison 9 Heparin versus prostaglandin E1, Outcome 1 Incidence of hepatic VOD.

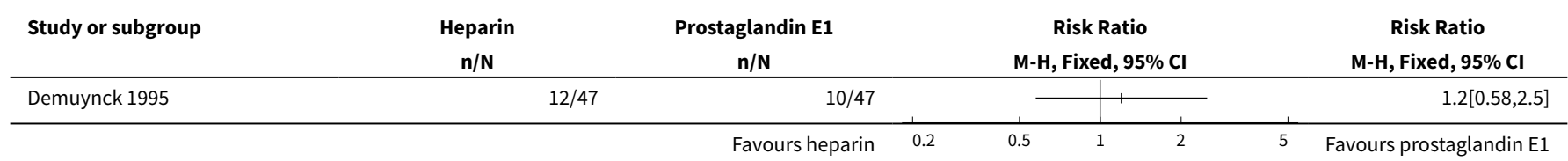


Analysis 9.2. Comparison 9 Heparin versus prostaglandin E1, Outcome 2 Mortality attributable to hepatic VOD.

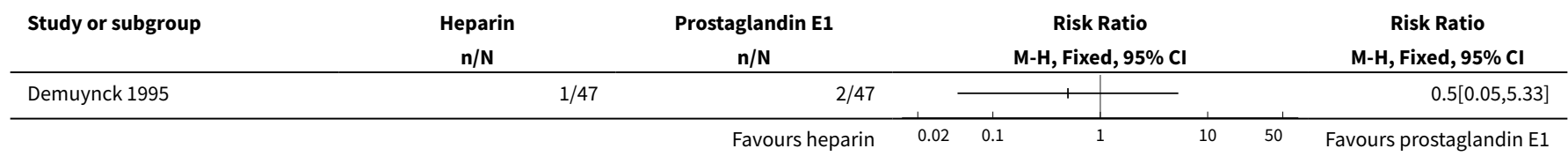

Analysis 9.3. Comparison 9 Heparin versus prostaglandin E1, Outcome 3 Frequency of adverse events.

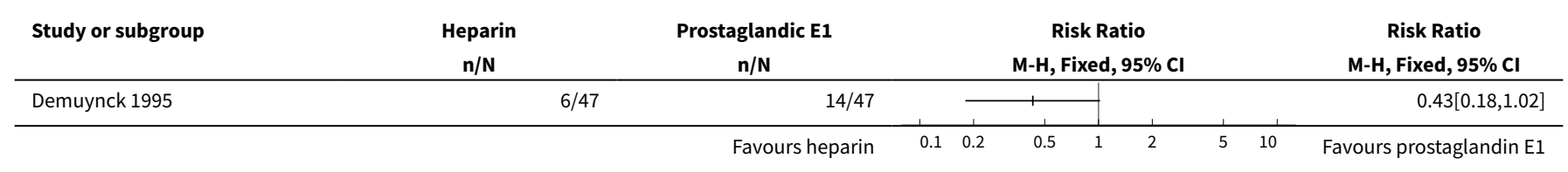

Comparison 10. Low molecular weight heparin versus prostaglandin E1

\begin{tabular}{lllll}
\hline Outcome or subgroup title & $\begin{array}{l}\text { No. of } \\
\text { studies }\end{array}$ & $\begin{array}{l}\text { No. of } \\
\text { partici- } \\
\text { pants }\end{array}$ & Statistical method & Effect size \\
\hline 1 Incidence of hepatic VOD & 1 & Risk Ratio (M-H, Fixed, 95\% Cl) & Totals not selected \\
\hline $\begin{array}{l}2 \text { Mortality attributable to hepat- } \\
\text { ic VOD }\end{array}$ & 1 & Risk Ratio (M-H, Fixed, 95\% Cl) & Totals not selected \\
\hline 3 Frequency of adverse events & 1 & Risk Ratio (M-H, Fixed, $95 \% \mathrm{Cl})$ & Totals not selected \\
\hline
\end{tabular}

Analysis 10.1. Comparison 10 Low molecular weight heparin versus prostaglandin E1, Outcome 1 Incidence of hepatic VOD.

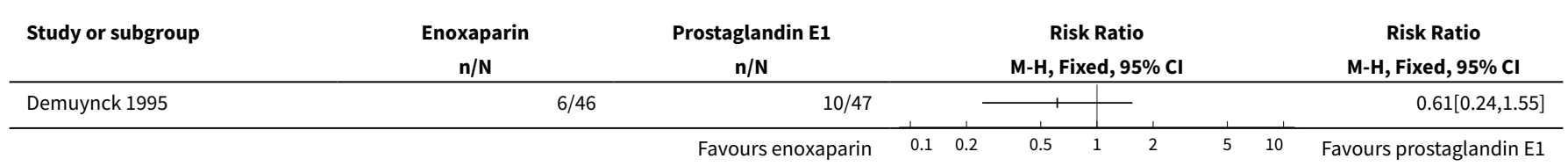

Analysis 10.2. Comparison 10 Low molecular weight heparin versus prostaglandin E1, Outcome 2 Mortality attributable to hepatic VOD.

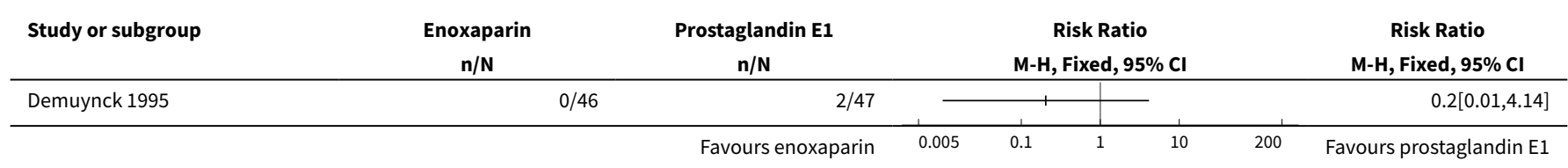


Analysis 10.3. Comparison 10 Low molecular weight heparin versus prostaglandin E1, Outcome 3 Frequency of adverse events.

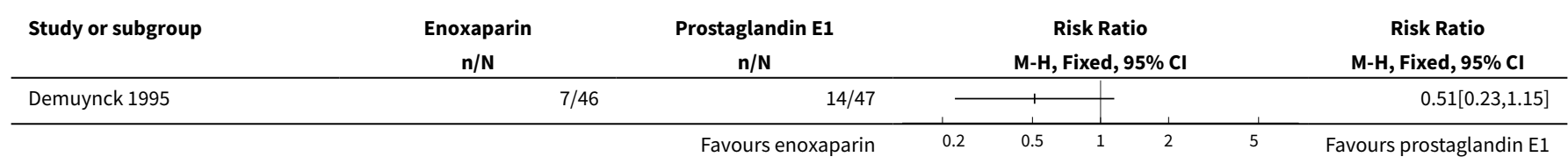

\section{APPENDICES}

\section{Appendix 1. CENTRAL search strategy}

\begin{tabular}{|c|c|}
\hline$\# 1$ & Stem Cell Transplantation \\
\hline \#2 & MeSH descriptor Hematopoietic Stem Cell Transplantation explode all trees \\
\hline \#3 & MeSH descriptor Bone Marrow Transplantation explode all trees \\
\hline \#4 & MeSH descriptor Peripheral Blood Stem Cell Transplantation explode all trees \\
\hline \#5 & MeSH descriptor Cord Blood Stem Cell Transplantation explode all trees \\
\hline \#6 & MeSH descriptor Mesenchymal Stem Cell Transplantation explode all trees \\
\hline$\# 7$ & $\begin{array}{l}\text { (bone marrow NEAR/2 transplant* }{ }^{\star} \text { ) or (bone marrow NEAR/2 graft* }{ }^{\star} \text { ) or (bone marrow NEAR/2 } \\
\text { trasplant }^{\star} \text { ) or (bone marrow NEAR/2 rescue*) }\end{array}$ \\
\hline \#8 & $\left(\right.$ stem cell$^{\star}$ or stem-cell*) \\
\hline \#9 & "progenitor cell*" \\
\hline \#10 & (ASCT or ABMT or PBPC or PBSCT or PSCT or BMT or SCT or HSCT) \\
\hline \#11 & (\#1 OR \#2 OR \#3 OR \#4 OR \#5 OR \#6 OR \#7 OR \#8 OR \#9 OR \#10) \\
\hline \#12 & MeSH descriptor Transplantation Conditioning explode all trees \\
\hline \#13 & myeloablat* $^{\star}$ \\
\hline \#14 & reduced intens* \\
\hline \#15 & (nonmyeloablat* or non-myeloablat*) \\
\hline \#16 & $\left(\right.$ mini-tra*splant ${ }^{\star}$ or minitra*splant $\left.{ }^{\star}\right)$ \\
\hline \#17 & (\#12 OR \#13 OR \#14 OR \#15 OR \#16) \\
\hline \#18 & MeSH descriptor Transplantation, Homologous explode all trees \\
\hline \#19 & (allograft* or allo-graft*) \\
\hline \#20 & (allotransplant* or allo-transplant ${ }^{\star}$ ) \\
\hline
\end{tabular}




\begin{tabular}{|c|c|}
\hline \#21 & (allotrasplant* or allo-trasplant*) \\
\hline \#22 & (allogen ${ }^{\star}$ or allo-gen ${ }^{\star}$ ) \\
\hline \#23 & $\begin{array}{l}\text { (allogen }{ }^{\star} \text { NEAR/5 transplant }{ }^{\star} \text { ) or (allogen }{ }^{\star} \text { NEAR/5 trasplant }{ }^{\star} \text { ) or (allogen* NEAR/5 graft }{ }^{\star} \text { ) or (allo- } \\
{\text { gen }{ }^{\star} \text { NEAR/5 rescue }}^{\star} \text { ) }\end{array}$ \\
\hline \#24 & $\begin{array}{l}\left.\text { (allo-gen* NEAR/5 transplant }{ }^{\star} \text { ) or (allo-gen* NEAR/5 trasplant* }\right) \text { or (allo-gen* NEAR/5 graft }{ }^{\star} \text { ) or (al- } \\
\text { lo-gen* NEAR/5 rescue }{ }^{\star} \text { ) }\end{array}$ \\
\hline \#25 & (homograft* or homo-graft*) \\
\hline \#26 & homolog* \\
\hline \#27 & (homotransplant* or homo-transplant ${ }^{\star}$ ) \\
\hline \#28 & (homotrasplant* or homo-trasplant ${ }^{\star}$ ) \\
\hline \#29 & (\#18 OR \#19 OR \#20 OR \#21 OR \#22 OR \#23 OR \#24 OR \#25 OR \#26 OR \#27 OR \#28) \\
\hline \#30 & MeSH descriptor Transplantation, Autologous explode all trees \\
\hline \#31 & (autograft* or auto-graft* $^{\star}$ ) \\
\hline \#32 & (autotransplant* or auto-transplant ${ }^{\star}$ ) \\
\hline \#33 & (autotra*splant* or auto-tra*splant ${ }^{\star}$ ) \\
\hline \#34 & (autolog* NEAR/5 (transplant* or graft* or trasplant* or rescue $\left.{ }^{\star}\right)$ ) \\
\hline \#35 & (\#30 OR \#31 OR \#32 OR \#33 OR \#34) \\
\hline \#36 & (\#11 OR \#17 OR \#29 OR \#35) \\
\hline \#37 & MeSH descriptor Hepatic Veno-Occlusive Disease explode all trees \\
\hline \#38 & (veno-occlusiv or venoocclusiv) \\
\hline \#39 & (veno-oclusiv* or venooclusiv ${ }^{\star}$ ) \\
\hline \#40 & (sinusoidal* adj3 obstruct* ${ }^{\star}$ \\
\hline \#41 & VOD \\
\hline \#42 & (\#37 OR \#38 OR \#39 OR \#40 OR \#41) \\
\hline \#43 & (\#36 AND \#42) \\
\hline
\end{tabular}

\section{Appendix 2. MEDLINE (OVID) search strategy}

1 HEPATIC VENO-OCCLUSIVE DISEASE/




$$
5
$$

6

VOD.tw.

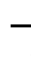

$$
7
$$

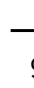$$
9
$$$$
10
$$$$
11
$$$$
11
$$$$
12
$$

$$
13
$$$$
14
$$

$$
\begin{aligned}
& 16 \\
& 17
\end{aligned}
$$$$
18
$$$$
\text { or/1-5 }
$$

exp STEM CELL TRANSPLANTATION/

Exp HEMATOPOIETIC STEM CELL TRAN SPLANTATION/

EXP BONE MARROW TRANSPLANTATION/

PERIPHERAL BLOOD STEM CELL TRANSPLANTATION/

CORD BLOOD STEM CELL TRANSPL ANTATION/

\section{MESENCHYMAL STEM CELL TRANSP LANTATION/}

(bone marrow adj2 (transplant\$ or graft\$ or trasplant\$ or rescue\$)).tw.

(stem cell\$ or stem-cell\$).tw.

"progenitor cell\$̣".tw.

(ASCT or ABMT or PBPC or PBSCT or PSCT or BMT or SCT or HSCT).tw.

or/7-16

MYELOABLATIVE CONDITIONING/ or NONMYELOABLATIVE CONDITIONING/ or REDUCED INTENSITY CONDITIONING/

\begin{tabular}{ll}
\hline 19 & myeloablat\$.tw. \\
\hline 20 & reduced intens\$.tw. \\
\hline 21 & (nonmyeloablat\$ or non-myeloablat\$).tw. \\
\hline 23 & (mini-tra?splant\$ or minitra?splant\$).tw. \\
\hline 24 & or/18-22 \\
\hline 25 & exp ALLOTRANSPLANTATION/ \\
\hline 26 & (allograft\$ or allo-graft\$).tw. \\
\hline 27 & (allotransplant\$ or allo-transplant\$).tw. \\
\hline 28 & (allotrasplant\$ or allo-trasplant\$).tw. \\
\hline 29 & (allogen\$ or allo-gen\$).tw. \\
\hline
\end{tabular}


(Continued)

30

(homograft\$ or homo-graft\$).tw.

31

32

homolog*.tw.

\section{3}

(homotransplant\$ or homo-transplant\$).tw.

\section{4}

(homotrasplant\$ or homo-trasplant\$).tw.

$$
35
$$

or/24-33

35

\section{AUTOTRANSPLANTATION/}

36

(autograft\$ or auto-graft\$).tw.

37 (autotransplant\$ or auto-transplant\$).tw.

38

(autotra?splant\$ or auto-tra?splant\$).tw.

39

(autolog\$ adj5 (transplant\$ or graft\$ or trasplant\$ or rescue\$)).tw.

40

or/35-39

41

42

17 or 23 or 34 or 40

43

6 and 41

$43 \quad$ randomised controlled trial.pt.

$44 \quad$ controlled clinical trial.pt.

45 randomized.ab.

\begin{tabular}{ll}
\hline 46 & placebo.ab. \\
\hline 47 & drug therapy.fs. \\
\hline
\end{tabular}

$48 \quad$ randomly.ab.

$49 \quad$ trial.ab.

\begin{tabular}{ll}
\hline 50 & groups.ab. \\
\hline 51 & or/43-50 \\
\hline 52 & humans.sh. \\
\hline 53 & 51 and 52 \\
\hline 54 & 42 and 53
\end{tabular}

\section{Appendix 3. EMBASE (OVID) search strategy}




\begin{tabular}{|c|c|}
\hline 1 & LIVER VENOOCCLUSIVE DISEASE/ \\
\hline 2 & (veno-occlusiv\$ or venoocclusiv\$).tw. \\
\hline 3 & (veno-oclusiv\$ or venooclusiv\$).tw. \\
\hline 4 & (sinusoidal\$ adj3 obstruct\$).tw. \\
\hline 5 & VOD.tw. \\
\hline 6 & or/1-5 \\
\hline 7 & exp STEM CELL TRANSPLANTATION/ \\
\hline 8 & EXP HEMATOPOIETIC STEM CELL TRAN SPLANTATION/ \\
\hline 9 & Exp BONE MARROW TRANSPLANTATION/ \\
\hline 10 & PERIPHERAL BLOOD STEM CELL TRANSPLANTATION/ \\
\hline 11 & CORD BLOOD STEM CELL TRANSPL ANTATION/ \\
\hline 12 & MESENCHYMAL STEM CELL TRANSP LANTATION/ \\
\hline 13 & (bone marrow adj2 (transplant\$ or graft\$ or trasplant\$ or rescue\$)).tw. \\
\hline 14 & (stem cell\$ or stem-cell\$).tw. \\
\hline 15 & "progenitor cell\$".tw. \\
\hline 16 & (ASCT or ABMT or PBPC or PBSCT or PSCT or BMT or SCT or HSCT).tw. \\
\hline 17 & or/7-16 \\
\hline 18 & $\begin{array}{l}\text { (MYELOABLATIVE CONDITIONING or NONMYELOABLATIVE CONDITIONING or REDUCED INTENSITY } \\
\text { CONDITIONING).sh,hw. }\end{array}$ \\
\hline 19 & myeloablat\$.tw. \\
\hline 20 & reduced intens\$.tw. \\
\hline 21 & (nonmyeloablat\$ or non-myeloablat\$).tw. \\
\hline 22 & (mini-tra?splant\$ or minitra?splant\$).tw. \\
\hline 23 & or/18-22 \\
\hline 24 & exp ALLOTRANSPLANTATION/ \\
\hline 25 & (allograft\$ or allo-graft\$).tw. \\
\hline 26 & (allotransplant\$ or allo-transplant\$).tw. \\
\hline 27 & (allotrasplant\$ or allo-trasplant\$).tw. \\
\hline 28 & (allogen\$ or allo-gen\$).tw. \\
\hline
\end{tabular}




\begin{tabular}{|c|c|}
\hline 30 & (homograft\$ or homo-graft\$).tw. \\
\hline 31 & homolog*.tw. \\
\hline 32 & (homotransplant\$ or homo-transplant\$).tw. \\
\hline 33 & (homotrasplant\$ or homo-trasplant\$).tw. \\
\hline 34 & or/24-33 \\
\hline 35 & AUTOTRANSPLANTATION/ \\
\hline 36 & (autograft\$ or auto-graft\$).tw. \\
\hline 37 & (autotransplant\$ or auto-transplant\$).tw. \\
\hline 38 & (autotra?splant\$ or auto-tra?splant\$).tw. \\
\hline 39 & (autolog\$ adj5 (transplant\$ or graft\$ or trasplant\$ or rescue\$)).tw. \\
\hline 40 & or/35-39 \\
\hline 41 & 17 or 23 or 34 or 40 \\
\hline 42 & 6 and 41 \\
\hline 43 & (random\$ or placebo $\$$ or single blind\$ or double blind\$ or triple blind\$).ti,ab. \\
\hline 44 & RETRACTED ARTICLE/ \\
\hline 45 & or/43-44 \\
\hline 46 & (animal\$ not human\$).sh,hw. \\
\hline 47 & (book or conference paper or editorial or letter or review).pt. not exp randomised controlled trial/ \\
\hline 48 & $\begin{array}{l}\text { (random sampl\$ or random digit\$ or random effect\$ or random survey or random regression).ti,ab. } \\
\text { not exp randomised controlled trial/ }\end{array}$ \\
\hline 49 & 45 not $(46$ or 47 or 48$)$ \\
\hline 50 & 42 and 49 \\
\hline
\end{tabular}

\section{CONTRIBUTIONS OFAUTHORS}

DKL Cheuk: conceiving of the review, protocol development, searching for trials, selection of studies, quality assessment of trials, data extraction, data input, data analyses, development of final review, corresponding author.

AKS Chiang: review of the protocol, selection of studies, quality assessment of trials, data extraction, data input, data analyses, development of final review.

SY Ha: review of the protocol and development of final review.

GCF Chan: review of the protocol and development of final review. 


\section{DECLARATIONS OF INTEREST}

Daniel KL Cheuk:None known

Alan KS Chiang:None known

Shau Yin Ha:None known

Godfrey CF Chan:None known

\section{SOURCES OF SUPPORT}

\section{Internal sources}

- The University of Hong Kong, Hong Kong.

\section{External sources}

- No sources of support supplied

\section{DIFFERENCES BETWEEN PROTOCOL AND REVIEW}

We did not produce a funnel plot because of insufficient number of studies identified. We did not conduct sensitivity analyses because all studies had high risk of bias. We assessed subgroup differences by examining the $\mathrm{I}^{2}$ statistic and performing Chi ${ }^{2}$ test for heterogeneity across subgroup results. For outcomes with substantial heterogeneity, we performed random-effects meta-analyses as a sensitivity analysis. We did not impute missing data, except for mortality and incidence of hepatic VOD data, but assumed that participants had not died or developed VOD if their data were missing.

\section{N DEX TERMS}

\section{Medical Subject Headings (MeSH)}

Antithrombin III [therapeutic use]; Cause of Death; Cholagogues and Choleretics [*therapeutic use]; Glutamine [therapeutic use]; Hematopoietic Stem Cell Transplantation [ ${ }^{*}$ adverse effects]; Heparin, Low-Molecular-Weight [therapeutic use]; Hepatic Veno-Occlusive Disease [mortality] [ ${ }^{\star}$ prevention \& control]; Plasma; Polydeoxyribonucleotides [therapeutic use]; Randomized Controlled Trials as Topic; Ursodeoxycholic Acid [*therapeutic use]

\section{MeSH check words}

Female; Humans; Male 